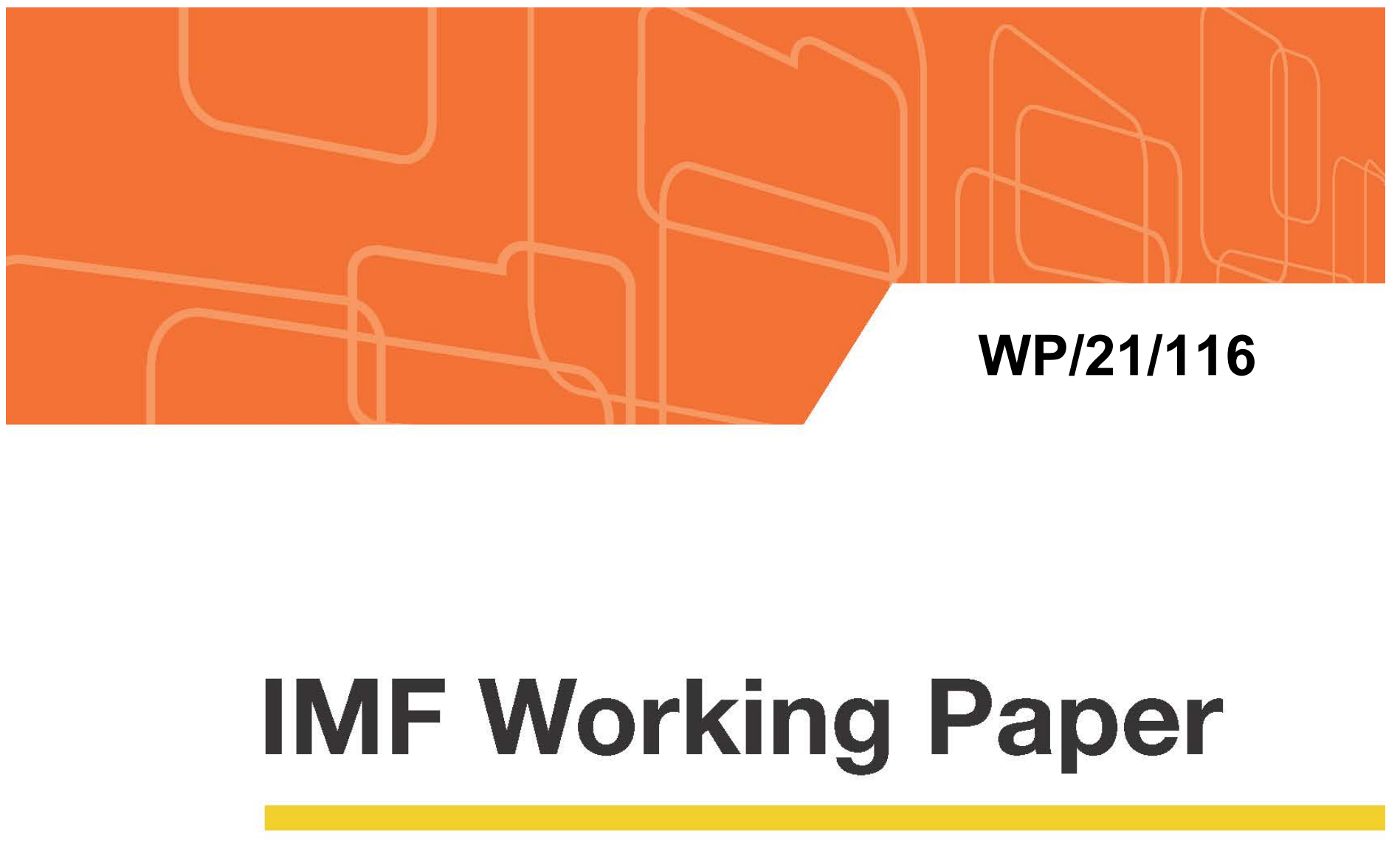

\title{
Financial Cycles - Early Warning Indicators of Banking Crises?
}

by Sally Chen and Katsiaryna Svirydzenka

IMF Working Papers describe research in progress by the author(s) and are published to elicit comments and to encourage debate. The views expressed in IMF Working Papers are those of the author(s) and do not necessarily represent the views of the IMF, its Executive Board, or IMF management.

$$
\text { I N T E R N A T | O N A L M O N E T A R Y F U N D }
$$




\title{
IMF Working Paper
}

Strategy, Policy, and Review Department

\section{Financial Cycles - Early Warning Indicators of Banking Crises? ${ }^{1}$ \\ Prepared by Sally Chen and Katsiaryna Svirydzenka}

Authorized for distribution by Petya Koeva Brooks

April 2021

\section{IMF Working Papers describe research in progress by the author(s) and are published to elicit comments and to encourage debate. The views expressed in IMF Working Papers are those of the author(s) and do not necessarily represent the views of the IMF, its Executive Board, or IMF management.}

\begin{abstract}
Can the upturns and downturns in financial variables serve as early warning indicators of banking crises? Using data from 59 advanced and emerging economies, we show that financial overheating can be detected in real time. Equity prices and output gap are the best leading indicators in advanced markets; in emerging markets, these are equity and property prices and credit gap. Moreover, aggregating this information flags financial crisis many years before the crisis. Lastly, we find that the length of financial cycles is of medium-term frequency, calling into question the longer frequency widely used in the estimation of countercyclical capital buffers.
\end{abstract}

JEL Classification Numbers: E30, E50, F47, G01, G20

Keywords: financial cycles, banking crises, early warning systems, macroprudential policy Author's E-Mail Address: sally.chen@bis.org, ksvirydzenka@imf.org

\footnotetext{
${ }^{1}$ This paper is based on the background work conducted for the IMF Policy Paper "Monetary Policy and Financial Stability" (IMF 2015). It benefited from discussions with Vikram Haksar, Tamim Bayoumi, Aleksandra Zdzienicka, and Stefan Laseen and comments from Jeremy Stein, Adolfo Barajas, Martin Cihak, Matthias Drehmann, Tommaso Mancini Griffoli, Gee Hee Hong, Pablo Lopez Murphy, Natalia Novikova, William Oman, Damiano Sandri, Tahsin Saadi Sedik, as well as other participants at the IMF and BIS seminars and the joint conference on "Financial Cycles and Regulation" at Bundesbank. Federico Diaz Kalan provided invaluable research assistance. All errors or omissions are the responsibility of the authors.
} 


\section{Contents}

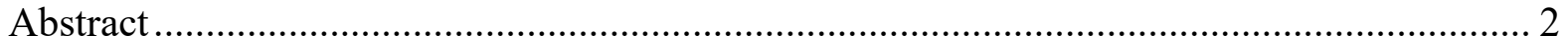

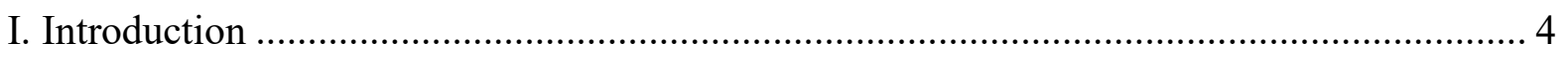

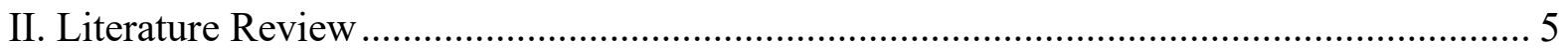

III. Financial cycles - Data, Methodology, and Stylized Facts ......................................... 8

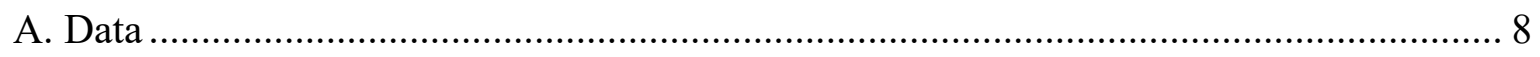

B. Dating Financial Cycles ...................................................................................... 9

C. Cycle Properties ............................................................................................ 10

D. Financial Cycle Gaps ............................................................................................ 13

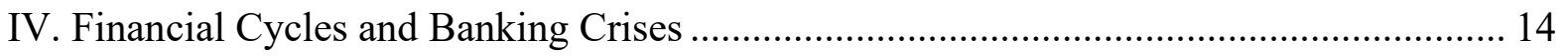

A. Stylized Facts ................................................................................................. 14

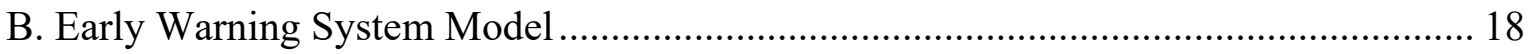

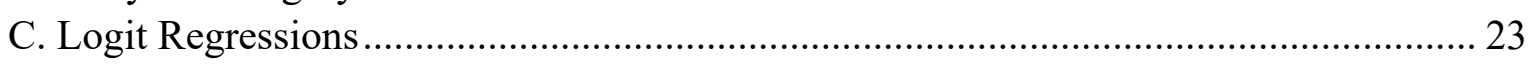

V. Why Is Credit not the Best Early Warning Indicator in AM? ..................................... 27

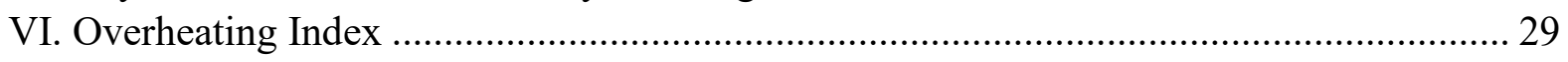

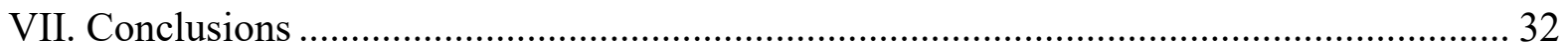

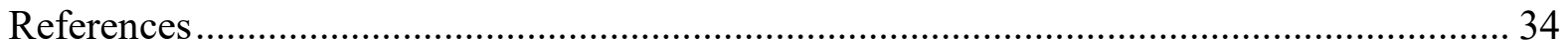

\section{Figures}

Figure 1. Example of How Peaks and Troughs Translate into Cycle Length....................... 10

Figure 2. Stylized Cycle: Advanced Markets ............................................................ 12

Figure 3. Stylized Cycle: Emerging Markets..................................................................... 12

Figure 4. Behavior Around Crisis Date (AM) .............................................................. 16

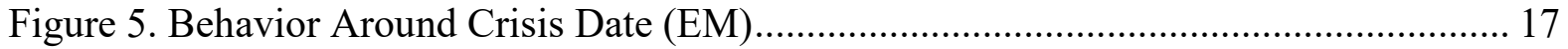

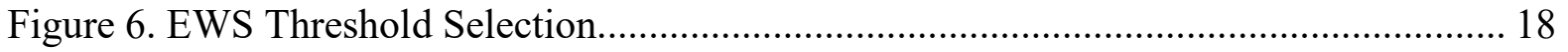

Figure 7. EWS Versus AUROC.............................................................................. 20

Figure 8. Early Warning System Results (2-sided filter)................................................. 21

Figure 9. Early Warning System Results (1-sided filter)............................................... 22

Figure 10. Early Warning System Results (Growth) ....................................................... 23

Figure 11. Logit Summary - Unconditional Probability of Banking Crisis ......................... 27

Figure 12. Credit in Percent of Total Assets ............................................................... 28

Figure 13. Overheating Index - Behavior around Crisis Episode ..................................... 30

Figure 14. Overheating Index - Percent of Crises Flagged ................................................. 30

Figure 15. Overheating Index - Country Examples ....................................................... 31

Figure 16. Overheating Index - Out of Sample ............................................................. 32

\section{Tables}

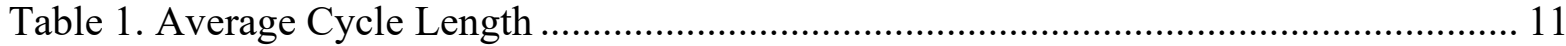

Table 2. Maximum and Minimum Periods of the Cycle ...................................................... 14

Table 3. Probability of Banking Crisis (AM; 2-sided filters) ............................................. 25

Table 4. Probability of Banking Crisis (AM; 1- and 2-sided filters with controls) ............... 26

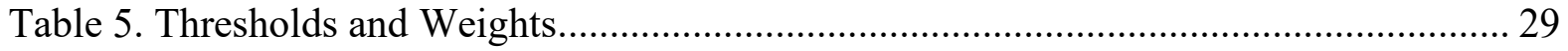




\section{Annexes}

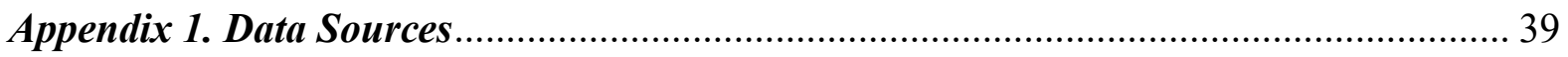

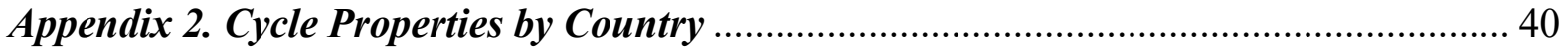

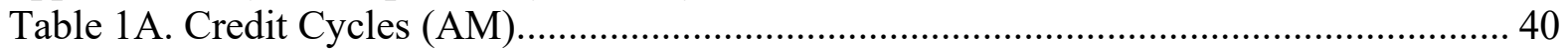

Table 1B. Credit Cycles (EM) ..................................................................................... 42

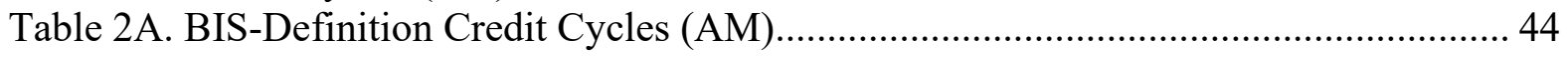

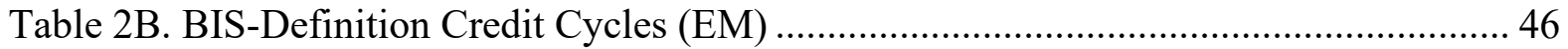

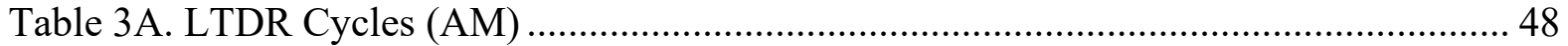

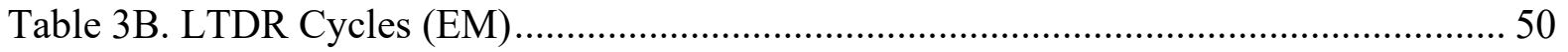

Table 4A. Equity Price Cycles (AM) ....................................................................... 52

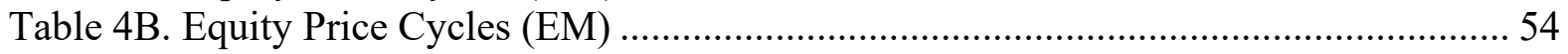

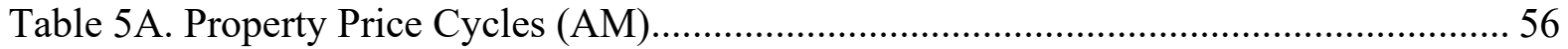

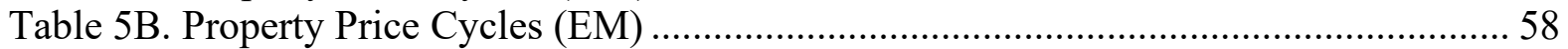

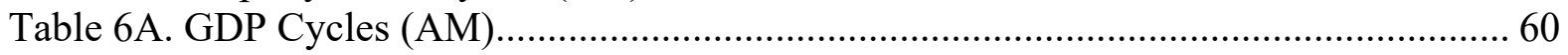

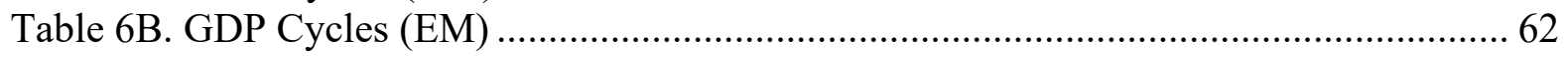

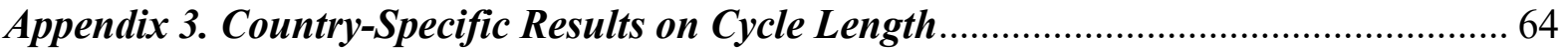

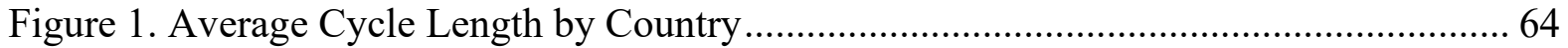

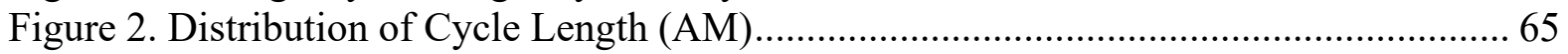

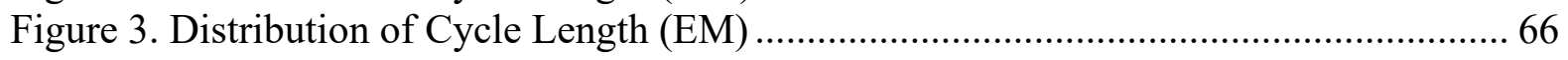

Appendix 4. Synchronization across Financial and Real Cycles.................................... 67

Table 2A. Synchronization of Financial Cycles within a Country (AM) .............................69 69

Table 2B. Synchronization of Financial Cycles within a Country (EM) ............................ 70

Table 3A. Synchronization of Financial and Real Cycles within a Country (AM) .............. 71

Table 3B. Synchronization of Financial and Real Cycles within a Country (EM)............... 72

Appendix 5. Comparison of Cycle Length to Claessens et al. (2011a and 2011b) ............. 73

Figure 1. Cycle Length across Different Approaches................................................... 74

Appendix 6. Robustness Checks for EWS: AUROC Estimations ............................... 75

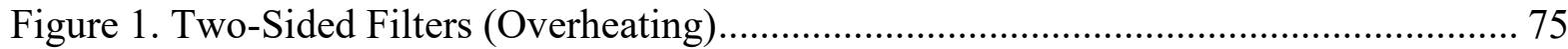

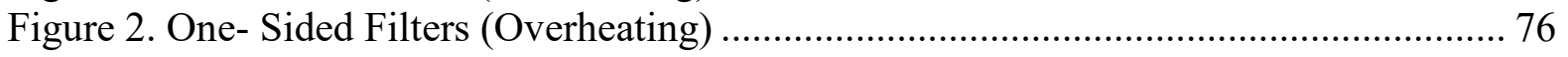

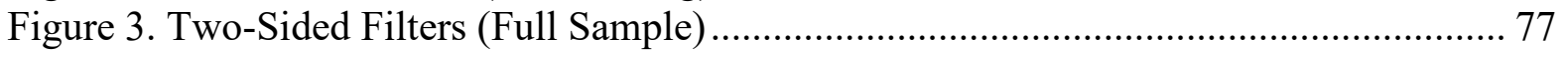

Figure 4. One-Sided Filters (Full Sample)...................................................................... 78 


\section{INTRODUCTION}

Amid current deliberations over policy normalization in a post-pandemic world, financial vulnerabilities that had been built up since before the pandemic - including, for example, stretched asset valuations - and their implications on the real economy are receiving growing attention. These concerns are not new. The booms and busts of financial markets and asset prices - or "financial cycles" - garnered attention following the Global Financial Crisis (GFC). During the GFC, the global economy bore painful witness to the intersection between financial excesses and economic instability. Since then, there is growing appreciation for the fact that financial leverage boosts growth in the short run, but also raises downside risks to the real economy over the medium term (IMF 2021). The extraordinary policy support that helped cushion the impact of the pandemic also raised financial leverage, already at historically high levels following the GFC. The key policy concern at the current juncture, therefore, is the thorny tradeoff between supporting still fragile growth and staving off financial crises down the road.

Policy advice, in reaction to current challenges, calls for targeted macroprudential measures that address pockets of financial excesses. These measures are often difficult to implement in real time - they require an understanding of the behavior and real economy implications of financial variables. Overall, there is a sense that shocks to financial indicators propagate differently from real indicators; and, financial indicators exhibit different cyclical properties than real indicators. Still, the cyclical properties of financial cycles, fundamental to the identification of financial excesses and early warning indicators, have yet to find a consensus.

One view on financial cycle, from the works of Borio and Lowe (2002), Borio and Drehmann (2009), and Drehmann et al. (2012), argues that peaks in financial cycles, filtered with lower frequencies, exhibit close association with systemic banking crises. A number of other studies echo this view and find financial cycles longer than business cycles (Aikman et al., 2015; Claessens et al., 2011a and 2011b; Galati et al., 2016; Schuler et al., 2015). This view underpins the calibration for the countercyclical capital buffer $(\mathrm{CCyB})$ required under the Basel III regulations. Under this framework, financial regulators extract long-term cycles in credit using HP filter with a smoothing parameter of 400,000 (cycle length of 8-30 years) to estimate the buffer needed for their banking system.

Recently, more nuanced views on financial cycles emerged, underscoring challenges facing policy makers. For example, using turning point analysis, Hiebert et al. (2014) show that in the Euro Area, the length of the credit cycle and the business cycle are roughly equal, while property and equity price cycles tend to be shorter. Using spectral analysis and unobserved components models, Gonzales et al. (2015) find that financial cycles are the same length as business cycles in several emerging markets. Moreover, critical views on the approaches used for cycle extraction, including dependence on HP filters - and the spurious results introduced by some of these approaches - contributed to the debate on financial cycles (Harvey and Jaeger, 1993; Harvey and Trimbur, 2008; Hamilton, 2018; Alessandri et al., 2021). 
Given different views, a key question for policymakers is thus how to measure financial cycles, what indicators to use and how to identify overheating in real time. These are the questions we sought to answer in our paper, based on a large country and time sample, using the most agnostic statistical approach. Specifically, we answer three questions. First, what are the stylized empirical characteristics of financial cycles - do financial cycles indeed last between 8 and 30 years? Second, which indicator has a better forecasting power in predicting financial crisis - is the medium- to long-term cycle in the credit-to-GDP ratio the best measure to use? And third, given these findings, what could be a practical approach for policymakers to assess financial overheating in real time?

We show that contrary to widely held beliefs, financial cycles are of medium-term frequency (lasting on average 6 years). Equity cycle is the shortest and with the largest amplitude, while credit and GDP have longer cycles, in line with business cycles. We find that emerging market cycles behave differently from advanced market cycles - they tend to be shorter and with greater amplitude. This suggest that a single rule extracting a cycle of the same length across countries may not be appropriate.

We also show that credit growth does not offer the most timely and accurate forecast of impending financial crisis. In terms of crisis prediction, credit-to-GDP ratio does not seem to be the best leading indicator. Instead, equity price and output gap seem to be the best predictors of banking crises in advanced economies. In emerging markets, equity, property, and credit gap indicators offer useful early warnings. This underscores the need to track multiple indicators, beyond credit.

Finally, we show that aggregating signals from the best leading indicators improves forecasting power. Warnings of a banking crisis can be seen up to five years in advance, even when assessing financial system overheating in real time. Such early warning power gives policy makers time to adjust policies to dampen financial overheating and for these measures to take effect, given lags in policy transmission.

The rest of the paper is structured as follows. Section II reviews the literature on financial cycles, summarizing different measurement approaches, as well as the literature on early warning systems. Section III outlines the data and methodology used to extract financial cycles and presents stylized facts about their behavior. Section IV explores the empirical relationship between financial cycles and the probabilities of banking crises. Section V presents a possible approach to synthesize insights presented here in an overheating index for early warning and policy response. Section VI concludes.

\section{LITERATURE REVIEW}

This paper contributes to two strands of interrelated literature. The first deals with measuring the financial cycle and investigating its statistical properties; the second is the vast empirical work on the early warning indicators of financial stress.

There is no consensus on the definition of a financial cycle. In a loose sense, financial cycle refers to the upturns and downturns in credit, asset prices, capital flows, or even exchange rate valuations. This understanding of financial cycles is based on the empirical evidence that 
credit and asset price booms and busts go hand-in-hand. Borio (2014) defined financial cycles as the "self-reinforcing interactions between perceptions of value and risk, attitudes towards risk and financing constraints, which translate into booms followed by busts. These interactions can amplify economic fluctuations and possibly lead to serious financial distress and economic dislocations." This observation aligns with early work, including that of Fisher (1933), Kindleberger (1978), and Minsky $(1986,1992)$, all of which focused on the interaction between boom-bust patterns in the financial system and the macroeconomy.

In recent years, researchers have attempted to devise an empirical measure of the financial cycle and investigate its properties, using several approaches:

- Turning point analysis: This analysis builds on the long tradition of identifying business cycles by dating their peaks and troughs. Started by Burns and Mitchell (1946), formalized by Bry and Boschan (1971) and extended by Harding and Pagan (2002a), this is the standard approach used by the NBER and CEPR to date American and European business cycles. Claessens et al. (2011a and 2011b) and Drehmann et al. (2012) were some of the first to apply this approach to identify financial cycles. The turning point analysis is agnostic, typically only constraining the cycle to a minimum pre-set length, thus allowing data to "speak".

- Frequency-based filters: These statistical filters require users to specify the length of cyclical frequencies to be extracted either explicitly, as in the bandpass filters of Baxter and King (1999) and Christiano and Fitzgerald (2003), or implicitly, as in the HodrickPrescott (HP) filter or any deviation from a trend otherwise defined. These filters are widely used to measure excess credit growth, as per BCBS guidelines, to determine countercyclical capital buffers. A variation on these filters is from Dell'Ariccia et al. (2012), which identifies asset booms by comparing the credit-to-GDP ratio to a backward-looking, rolling, country-specific, cubic trend. This approach requires an a priori decision on the cyclical length.

- Spectral density estimation: Spectral analysis decomposes a time series into a combination of cosine/sine waves and can help identify the dominant cyclical frequency in the data (Preistley, 1999). Aikman et al. (2015) use this approach to identify the dominant frequency in credit cycle, and Schuler et al. (2015) apply power cohesion - its multivariate equivalent - to identifying common cyclical frequencies across a set of real and financial indicators. This approach can only be applied to stationary data and therefore not applicable to financial price and stock data as they are nonstationary. Making the data stationary, either by differencing or by extracting a deviation relative to a trend using HP or band-pass filters involves making an explicit assumption about the dominant frequency in the data, which undermines the goal of the exercise. In other words, detrending methods affect the cyclical properties of time series and as a result can offer disparate information, despite the same spectral density estimation (see for example, Canova, 1998, and Schuler, 2018).

- Unobserved component time series models: These models apply Kalman filter to unobserved components time series models to extract cycles (Harvey, 1989; Durbin and Koopman, 2012). This approach is common in business cycle analysis. Koopman and 
Lucas (2005) were among the first to apply it to financial variables. Galati et al. (2016) use this approach explicitly to investigate the characteristics of financial cycles in the United States and the Euro Area. The weakness of this approach is that it requires the user to make assumptions on the smoothness of the underlying trend of the series, which determines how much fluctuation in the data is assigned to the trend as opposed to the cycle, as well as on the appropriate stochastic process for the cycle itself. The choice, as a result, affects the cyclical properties of the extracted component; studies find evidence of spurious cycles if the true data generating process is difference stationary (Nelson, 1988).

- Aggregation: An additional choice is whether and how to extract a common financial cycle from multiple indicators. One approach is to estimate cycles of individual financial variables and take averages (Drehmann et al., 2012) or aggregate using principal component analysis (Hiebert et al., 2014). Others study cyclical properties in an explicit multivariate model (Koopman and Lucas, 2005; Schuler et al., 2015). Aggregating allows for extracting the properties of the common cycle but may miss the idiosyncratic properties of the underlying data.

From the empirical methods summarized above, only the turning point analysis allows for an independent, unbiased study of the cyclical properties of the data. This is the preferred approach followed in this paper. All the other methods make specific ex-ante assumptions about the characteristics of the cycle before extracting it. We prefer not to aggregate the data prior to studying its cyclical properties; instead, we aggregate the warning signals in the last step.

This paper also contributes to the large literature on the early warning indicators of banking crisis (see surveys in Demirgüç-Kunt and Detragiache, 2005; Frankel and Saravelos, 2012; and Chamon and Crowe, 2012). This work is typically eclectic and can be broadly divided into the following categories:

- Probit/Logit: These are limited dependent variable regression models, where the probability of a crisis is estimated as a function of a number of variables. Papers on currency crisis by Eichengreen et al. (1995) and Frankel and Rose (1996) were some of the first to use this approach. The benefit of the technique is that it allows one to assess the relative importance of variables jointly, but this approach also makes it difficult to consider a large number of indicators at the same time.

- Signal extraction: This non-parametric approach was proposed by Kaminsky et al. (1998), again in the context of currency crises, and involved establishing a threshold above which a crisis is more likely to occur. Each variable is considered in isolation, and the thresholds can be country and variable specific, based on a common reference percentile. Variations of this Early Warning Systems (EWS) approach are widely used in the IMF work on crisis vulnerabilities (Ahuja et al., 2017).

- Decision trees and machine learning: More recent non-parametric approaches include: (i) decision trees, where the thresholds are estimated recursively (Ghosh and Ghosh, 2003; Frankel and Wei, 2005; Alessi and Detken, 2018), (ii) machine learning, such as artificial neural networks, which are complex non-linear multi-layer and completely data- 
driven inference procedures focused on forecasting accuracy (Nag and Mitra, 1999; Apoteker and Barthelemy, 2000; Holopainen and Sarlin, 2017; Beutel et al., 2019); and (iii) Markov switching models, which focus on identifying shifts from "tranquil times" to "speculative times," allowing the probabilities of switching between states to be a function of fundamentals and expectations (Cerra and Saxena, 2002; Martinez Peria, 2002).

Of these, we work with signal extraction and logit. Machine learning approaches, as recent debates in the AI community highlighted, can be biased by inputs and reinforce existing biases. In addition, Beutel et al. (2019) show that while machine learning methods often attain a very high in-sample fit for banking crises, they are outperformed by more standard approaches in recursive out-of-sample evaluations.

\section{FinanCial CyCles - Data, Methodology, ANd Stylized Facts}

Financial cycles are extracted using a two-step approach. First, we date the peaks and troughs of the variables using the Harding and Pagan (2002a) turning point algorithm. In the second step, we use the empirically determined frequencies as inputs for calculating cyclical deviations from the trend using the Christiano and Fitzgerald band pass filter.

\section{A. Data}

We study cycles in three interrelated and complementary measures of financial activity: (i) quantity indicators, as measured by the quantity of private sector credit extended by the banking system and by all financial institutions, deflated by CPI; (ii) price indicators, as measured by real equity and property prices; and (iii) leverage or noncore funding indicators, as measured by the loan-to-deposit ratio in the banking system. We compare their performance to the performance of other popular measures of financial overheating (such as the growth rates of these series and the behavior of credit in percent of GDP) and to the performance of standard variables of interest for monetary policy (output gap and deviation of inflation from the target).

- Private credit, from the International Financial Statistics (IFS) database, measures aggregate claims on the private sector by banks. We supplement it with the total credit to the private non-financial sector from the Bank of International Settlements (BIS) database (Dembiermont et al., 2013), which, as a proxy of the total private sector credit, measures credit extended by banks, other financial institutions, non-financial institutions, households, and others. It is, however, only available for a smaller sub-set of countries.

- Price series - real equity and property prices - serve as proxies for the booms and busts in asset markets. This is the dataset put together by the IMF Research department, using data from OECD and Global Property Guide. Equity prices are share price indices weighted with the market value of outstanding shares and are from Haver.

- Loan-to-deposit ratio (LTDR) is a widely used measure of liquidity in the banking system, and serves as a proxy for bank leverage from noncore funding (Hahm et al., 
2013). The LTDR ratio is constructed based on the loan and deposit data from the IFS; the larger the ratio of loans-to-deposits, the greater the dependence on non-core funding.

- Real activity indicators include GDP, consumption, and investment from the World Economic Outlook database, output gap extracted from GDP data using the same approach as financial cycles, and inflation deviation from target, drawing on the IFS and IMF Research department.

All variables are quarterly, covering $1960-2014^{2}$, depending on the availability, and are seasonally adjusted. Credit, total credit, equity and property prices are deflated by CPI. See Appendix 1 for the summary of data sources.

The country sample includes 34 advanced market countries (AM) and 25 emerging market countries (EM), as follows:

AM sample: Australia, Austria, Belgium, Canada, Cyprus, Czech Republic, Denmark, Estonia, Finland, France, Germany, Greece, Hong Kong SAR, Iceland, Ireland, Israel, Italy, Japan, Korea, Luxembourg, Malta, Netherlands, New Zealand, Norway, Portugal, Singapore, Slovak Republic, Slovenia, Spain, Sweden, Switzerland, Taiwan Province of China, United Kingdom, and United States.

EM sample: Argentina, Brazil, Bulgaria, China, Colombia, Croatia, Hungary, India, Indonesia, Lithuania, Malaysia, Mexico, Philippines, Poland, Russia, Serbia, South Africa, Thailand, Turkey, Ukraine, Uruguay, Latvia, Kazakhstan, Romania, Vietnam.

We do not include low-income developing countries in our analysis due to data constraints.

\section{B. Dating Financial Cycles}

To extract financial cycles, we first identify their properties. We date cycle peaks and troughs using the Harding and Pagan (2002a) turning point algorithm, following the approach in Claessens et al. (2011a and 2011b). The turning points allow us to determine the average length of the cycle in financial and macroeconomic variables across countries; our approach is purposefully agnostic (unlike in Drehmann et al., 2012), given reservations noted in Literature Review.

A peak in a quarterly log-level series $f_{t}$ occurs at time $t$ if:

$$
\left\{\left[\left(f_{t}-f_{t-2}\right)>0,\left(f_{t}-f_{t-1}\right)>0\right] \text { and }\left[\left(f_{t+2}-f_{t}\right)<0,\left(f_{t+1}-f_{t}\right)<0\right]\right\}
$$

A cyclical trough occurs at time $t$ if:

$$
\left\{\left[\left(f_{t}-f_{t-2}\right)<0,\left(f_{t}-f_{t-1}\right)<0\right] \text { and }\left[\left(f_{t+2}-f_{t}\right)>0,\left(f_{t+1}-f_{t}\right)>0\right]\right\}
$$

\footnotetext{
${ }^{2}$ The endpoint of our analysis is set at 2014 as it is the date of the latest banking crisis per Laeven and Valencia, 2018).
} 
The distance between the peaks and troughs allows one to determine the average length of a cycle for a financial series in a country. A series with more turning points in a given time period - such as property prices in the UK - will have a shorter cycle than a series where the turning points are less frequent, such as property prices in Japan. The property price series for Japan has only three peaks and two troughs over 45 years, while the UK series has seven peaks and eight troughs over the same time period. As a result, a typical length of the Japanese property price cycle upswing is about seven years, and about 10 years in the downswing; these measures amount to an average cycle length of 17 years. For the UK property price cycle, the upswing lasts about four years, the downswing about two years, averaging to closer to six years for a cycle duration (see Figure 1 for an example).

More generally, the length of the cycle in a financial series $i$ in country $j$ is the sum of the average duration of its upswing and downswing phases:

$$
L_{i}^{j}=\bar{L}_{\text {up }}+\bar{L}_{\text {down }}=\frac{1}{n} \sum_{j=1}^{n} D_{j}^{u p}+\frac{1}{m} \sum_{j=1}^{m} D_{j}^{\text {down }}
$$

The duration of an upturn $D_{j}^{u p}$ is the number of quarters it takes for the variable to reach the next peak after the trough. The duration of a downturn $D_{j}^{\text {down }}$ is the number of quarters between a peak and the next trough. The length of a property price cycle for advanced or emerging economies as a group is therefore the average of the lengths of property price cycles among the countries in our advanced/emerging economy sample.
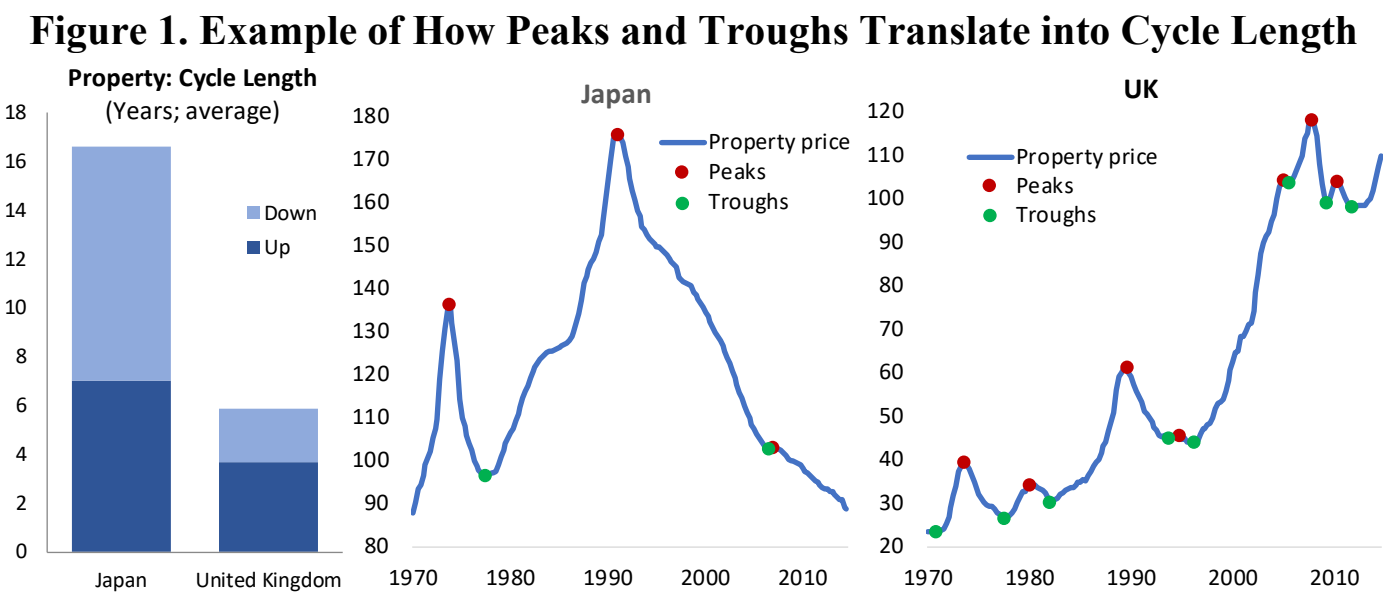

Other cyclical characteristics include amplitude, slope, and synchronicity. The amplitude of a downturn measures the change from a peak to the next trough. Slope is the ratio of amplitude to duration.

\section{Cycle Properties}

A complete cycle is defined as the movement from trough to peak to the next trough. Overall, we identify 251 complete credit cycles, 356 equity price cycles, 208 in property prices, and 
383 LTDR cycles (Table 1). Their stylized properties are summarized graphically in Figures 2 and 3. See Appendix 2 for country-specific results and Appendix 3 for the distribution of the cycle length.

We find that the length of financial cycles is on par with, or shorter, than that of business cycles. Equity cycle tends to be the shortest, lasting on average 3 to 4 years, and has one of the largest amplitudes, with a swing from trough to peak of over 60 percent on average. This result is in line with the more frequent fluctuations in stock prices. Bank credit and GDP tend to have the longest cycles, with long build-ups (around 5-6 years) and faster downturn (about 1-1.5 years). Their expansion amplitudes (50-90 percent for credit, 25-30 percent for GDP) tend to be much larger than the contraction amplitude (10-30 percent for credit, 4-7 percent for GDP). Loan-to-deposit ratio, real estate and equity prices tend to have peaks and slumps of relatively equal length and last on average 3 to 5 years.

We also find that emerging market cycles behave differently from advanced market cycles they tend to be shorter and with greater amplitude. This finding reflects, among other factors, that emerging economies have experienced more frequent policy regime switches, shocks to trend growth, and are more vulnerable to sudden stops in emerging markets (see, for example Aguiar and Gopinath, 2007). Credit cycle in particular tend to be more volatile in EMs, with larger amplitude and much larger contraction, indicating that the process of financial deepening in EMs faces larger hurdles.

The long buildup and the relatively swift downturns, particularly in AMs, reflect the procyclical and endogenous nature of leverage. Easy credit conditions that lift asset prices can lead to more leverage while deleveraging during downturns can weigh on asset prices further, exacerbating the downward spiral in asset valuation (Geanakoplos, 2010; Adrian and Shin, 2012). This negative cycle can result in defaults, rising NPLs, and banking crises.

Table 1. Average Cycle Length

\begin{tabular}{|c|c|c|c|c|c|c|c|c|}
\hline & Equity & Property & LTDR & Credit & Total credit & GDP & C & $\mathrm{I}$ \\
\hline \multicolumn{9}{|c|}{$\begin{array}{l}\text { Emerging Markets } \\
\end{array}$} \\
\hline Number of cycles & 125 & 42 & 92 & 107 & 54 & 37 & 33 & 58 \\
\hline \multicolumn{9}{|l|}{ Cycle length (years): } \\
\hline Average & 3.2 & 4.1 & 3.6 & 6.0 & 6.3 & 6.3 & 5.6 & 4.8 \\
\hline Median & 3.1 & 3.6 & 3.6 & 5.2 & 6.0 & 5.5 & 5.5 & 4.1 \\
\hline Standard deviation & 0.6 & 1.6 & 1.0 & 2.4 & 2.3 & 2.3 & 2.4 & 1.8 \\
\hline \multicolumn{9}{|c|}{ Advanced Markets } \\
\hline Number of cycles & 231 & 166 & 291 & 144 & 117 & 126 & 113 & 210 \\
\hline \multicolumn{9}{|l|}{ Cycle length (years): } \\
\hline Average & 3.8 & 5.2 & 4.2 & 7.1 & 7.3 & 6.7 & 6.7 & 4.7 \\
\hline Median & 3.5 & 4.7 & 3.9 & 6.6 & 6.4 & 5.9 & 5.7 & 4.5 \\
\hline Standard deviation & 0.9 & 2.0 & 1.3 & 2.7 & 3.4 & 3.0 & 3.5 & 1.3 \\
\hline Total number of cycles & 356 & 208 & 383 & 251 & 171 & 163 & 146 & 268 \\
\hline
\end{tabular}


Figure 2. Stylized Cycle: Advanced Markets

(Based on the properties of an average cycle as identified by Harding and Pagan algorithm)

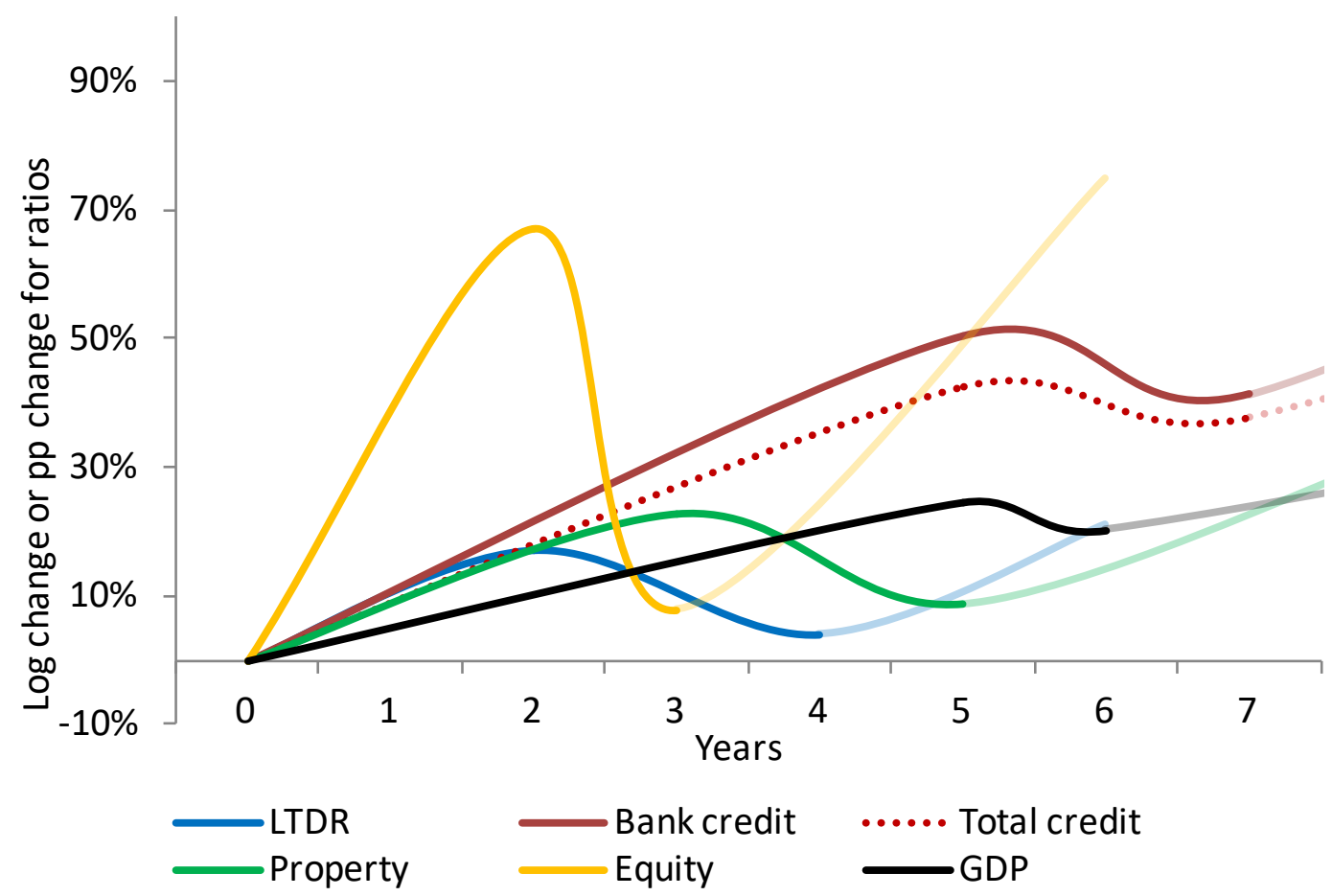

Figure 3. Stylized Cycle: Emerging Markets

(Based on the properties of an average cycle as identified by Harding and Pagan algorithm)

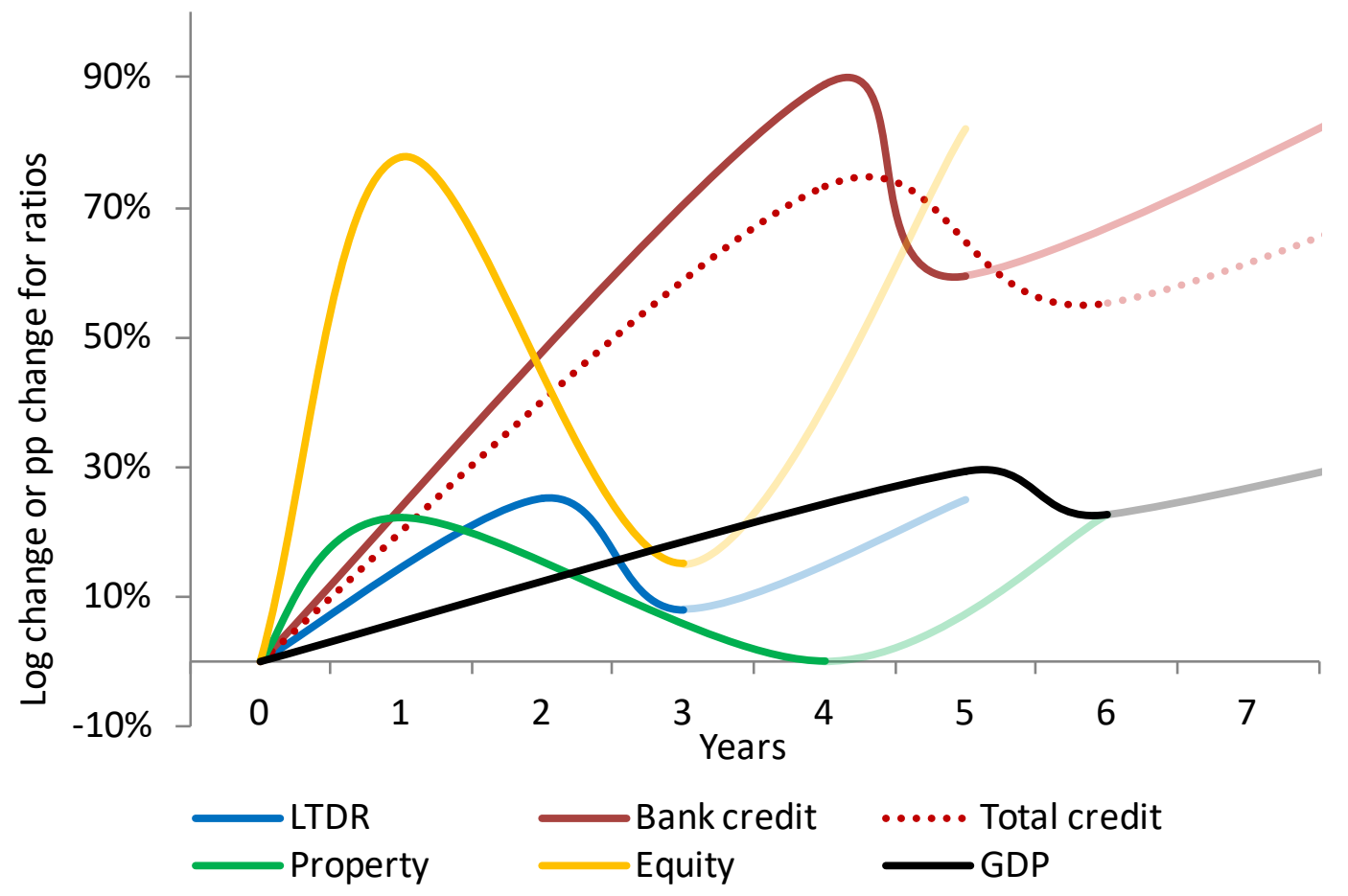


Many of our findings on the length of financial cycles are similar to those found in Claessens et al. (2011a and 2011b). We find that the median length for the equity price cycle is around 3 years and property price cycle, around 4 years (Appendix 5). Where we differ is on the length of the business cycle: they find the median length to be under two years, while we find it is closer to six years. Claessens' finding is at odds with NBER and CPER dating of business cycles in the US and Euro Area, which finds an average cycle on average of five years. This result also accounts for their finding of financial cycle being longer than the business cycle.

Lastly, we show that financial cycles tend to be more synchronized in AMs rather than EMs and that financial and business cycles are not perfectly synchronized (Appendix 4). This has two implications. First, the interaction between financial and business cycles raises the possibility of spillovers. Second, imperfect synchronization of financial and business cycles leaves scope for macroprudential policy to supplement monetary policy in achieving financial stability goals.

\section{Financial Cycle Gaps}

Having identified the typical length of a cycle in a financial series, we use it as inputs into the Christiano and Fitzgerald band pass filter to calculate cyclical deviations from the trend - i.e. financial cycle gaps. ${ }^{3}$ We chose to focus on cyclical deviations as a measure of financial overheating because cross-country differences in financial development and financial structure suggest that the level at which financial excesses could trigger a banking crisis could vary across countries.

We set the time range for the filter according to the sample average of cycle length in either EM or AM country group minus/plus two standard deviations in the sample as reported in Table 1; Table 2 reports the range of the frequencies to be extracted. For robustness, we also look at cycles in the range of mean $+/-0.5$ and +/- 1 standard deviation, and also at gaps identified with the HP filter and deviation from quadratic time trend.

A final note on cycle extraction - we report results for two-sided and one-sided filters to highlight the difficulties of real-time forecasting and the structural features of variables studied. The two-sided filter is estimated for the complete time sample, while the one-sided filter is estimated recursively, at each time point only using the information available up until that point, with no foresight of the future. The two-sided filter gives a structural view of how financial variables behave around the crisis episode and offers a clearer sense for the best indicators for monitoring, leveraging perfect hindsight. That said, real time application of two-sided filters requires an understanding of the drivers that shape variable behavior and the attendant impact on the real economy - something difficult to achieve ex ante with precision. One-sided filter thus acknowledges the difficulties in making real time inference; as a result and not surprisingly, its signal extraction could be much lower. For robustness, we compare the performance of financial gaps to the growth in the underlying series, commonly used to measure financial booms and busts.

\footnotetext{
${ }^{3}$ The only variable that is treated differently is inflation, where the inflation gap is measured as the deviation from the policy target
} 
Table 2. Maximum and Minimum Periods of the Cycle

(In quarters)

\begin{tabular}{lcc}
\hline & $\begin{array}{c}\text { Minimum length } \\
\text { of the } \mathbf{c y c l e}\left(\mathbf{p}_{\mathrm{I}}\right)\end{array}$ & $\begin{array}{c}\text { Maximum } \\
\text { length of the } \\
\mathbf{c y c l e}\left(\mathbf{p}_{\mathrm{h}}\right)\end{array}$ \\
\hline Credit & \multicolumn{2}{c}{ Advanced } \\
Markets \\
Potal credit & 5 & 50 \\
Equity prices & 2 & 56 \\
LTDR & 5 & 36 \\
GDP & 8 & 22 \\
& 7 & 27 \\
& 3 & 51 \\
Credit & & \\
Total credit & & \\
Property prices & 7 & 43 \\
Equity prices & 8 & 44 \\
LTDR & 6 & 29 \\
GDP & 7 & 18 \\
\hline
\end{tabular}

\section{Financial Cycles And Banking CRises}

\section{A. Stylized Facts}

Our variable of interest is the incidence of banking crises as identified in the Laeven and Valencia database $(2008,2012,2018)$ and the extent to which the swings in financial cycles could help predict the onset of these crises. Laeven and Valencia define a systemic banking crisis as an episode when a country's corporate and financial sectors experience a large number of defaults, and financial institutions and corporations face difficulties repaying contracts on time, leading to sharp increases in NPLs.

Before going into the analytics, we study the average behavior of financial cycles before, during, and immediately after the time of the crisis (Figures 4 and 5). ${ }^{4}$ Looking at the evolution of average two-sided gaps around the crisis periods (first row charts), we find that equity and property prices tend to peak before the crisis, making them good leading indicators. Equity prices tend to bottom out in a year's time, while it takes the property price boom two years to unwind. The role of the private credit, by contrast, is uncertain. In AMs, it peaks shortly before the crisis. In EMs, on the other hand, it peaks in the year of the crisis, which weakens its role for early warning.

\footnotetext{
${ }^{4}$ Note that the equity and inflation results for EMs are shown on the right-hand axis.
} 
Behavior of total private credit (BIS measure) - which peaks after the crisis - suggests that other financial institutions pick up the slack in a crisis as banks deleverage. This is more the case for AMs rather than EMs, with financial systems in EM stills very much bank-based. Credit-to-GDP ratio does not appear to have substantial early warning power. The rise in the ratio during and right after the crisis can be attributable to the output contractions that have historically brought forth debt crisis - as income falls and debt affordability deteriorates and the subsequent periods of forced deleveraging.

Leverage and non-core funding - proxied by the loan-to-deposit ratio (LTDR) - offer longer lead time for crisis warning, peaking two years before the crisis in AMs and four years before the crisis in EMs. This could be a sign of over borrowing, with banks' increased reliance on wholesale funding leading to asset price booms a few years down the road. In EMs, there is an additional peak in the year of and shortly after the crisis, which could be the result of bank runs and the narrowing of the deposit base.

Neither output, nor inflation seem to be a very good early warning indicator. In AMs they peak during the crisis, and in EMs they lag the crisis, with output falling and inflation spiking the year after the crisis. In EMs, there seems to be some merit in tracking sustained positive output gaps, and in AMs, the sustained positive deviation of inflation from target. Both tend to show overheating pressures in the three-year period before the crisis.

While results for one-sided filters illustrate the difficulty of assessing overheating in real time, they still offer signs of overheating three to four years prior to the crisis, with positive financial cycle gaps (the second row charts in Figures 4 and 5). For AMs, equity prices provide some guidance four years, property prices two years, and credit one year before the crisis. In EMs the performance is not as clear cut, but the tendency for positive gaps prior to the crisis and negative thereafter remains.

Results for the growth rate of the underlying series used to compute the cycles - a commonly-used measure in policy analysis - seem to be weaker when compared with the results of the financial gap analysis (the third row charts in Figures 4 and 5). We do see a peak in the growth of credit, property and LTDR two-three years before the crisis in AMs, and broad boom in equity prices, which evidenced multiple peaks. The results for EMs are not as clear cut. 


\section{Figure 4. Behavior Around Crisis Date (AM)}

(Percent deviation from the trend; average across gap estimates)
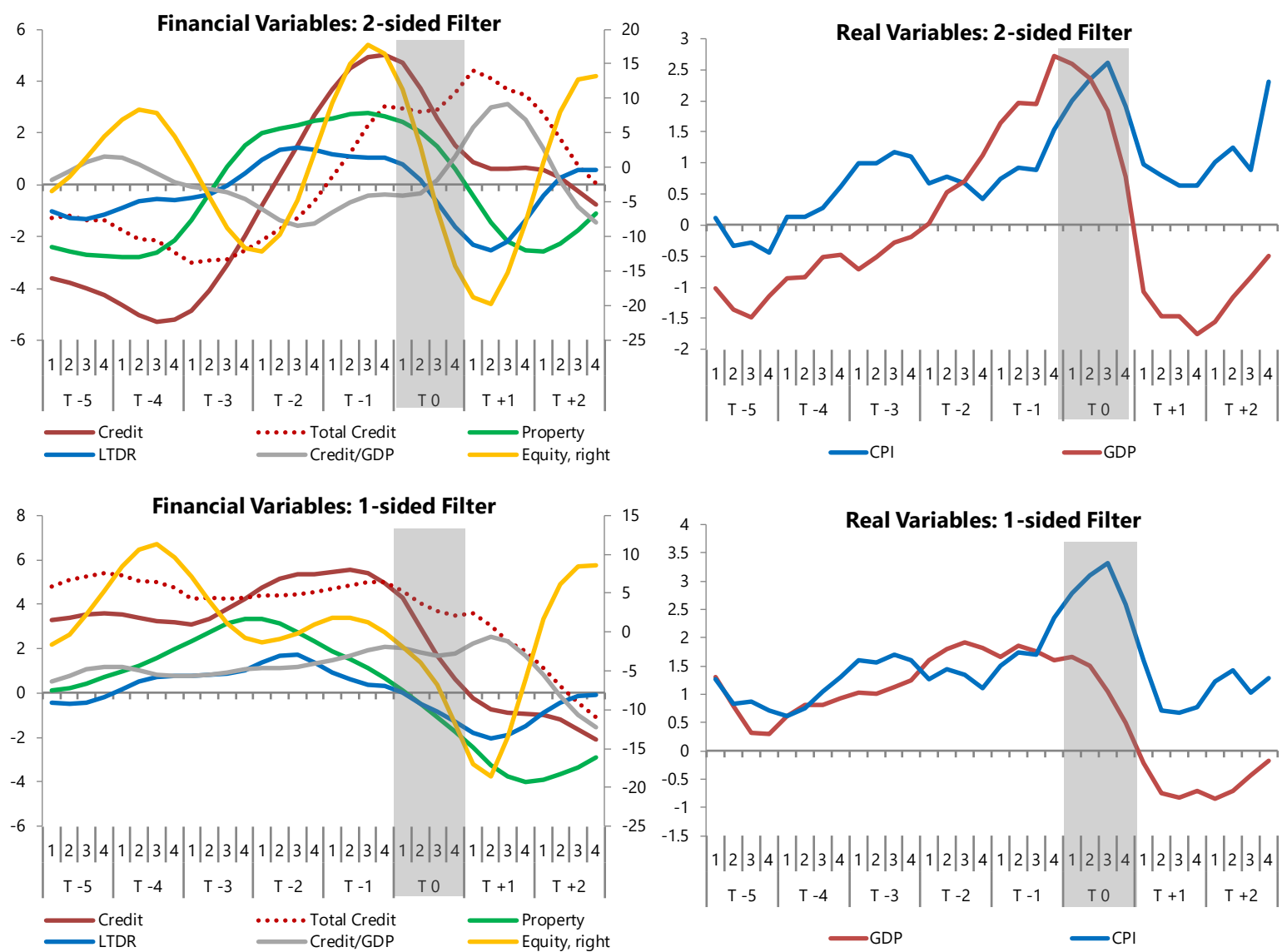

Financial Variables: Year-on-year Growth
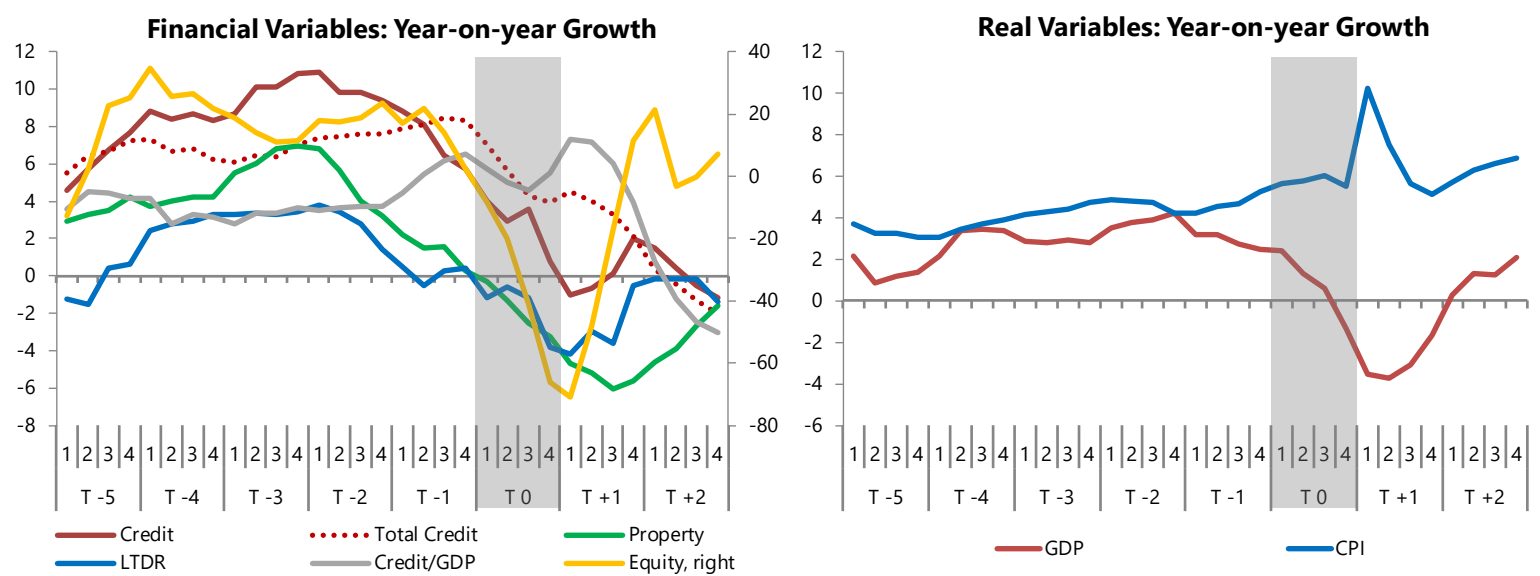
Figure 5. Behavior Around Crisis Date (EM)

(Percent deviation from the trend; average across gap estimates)
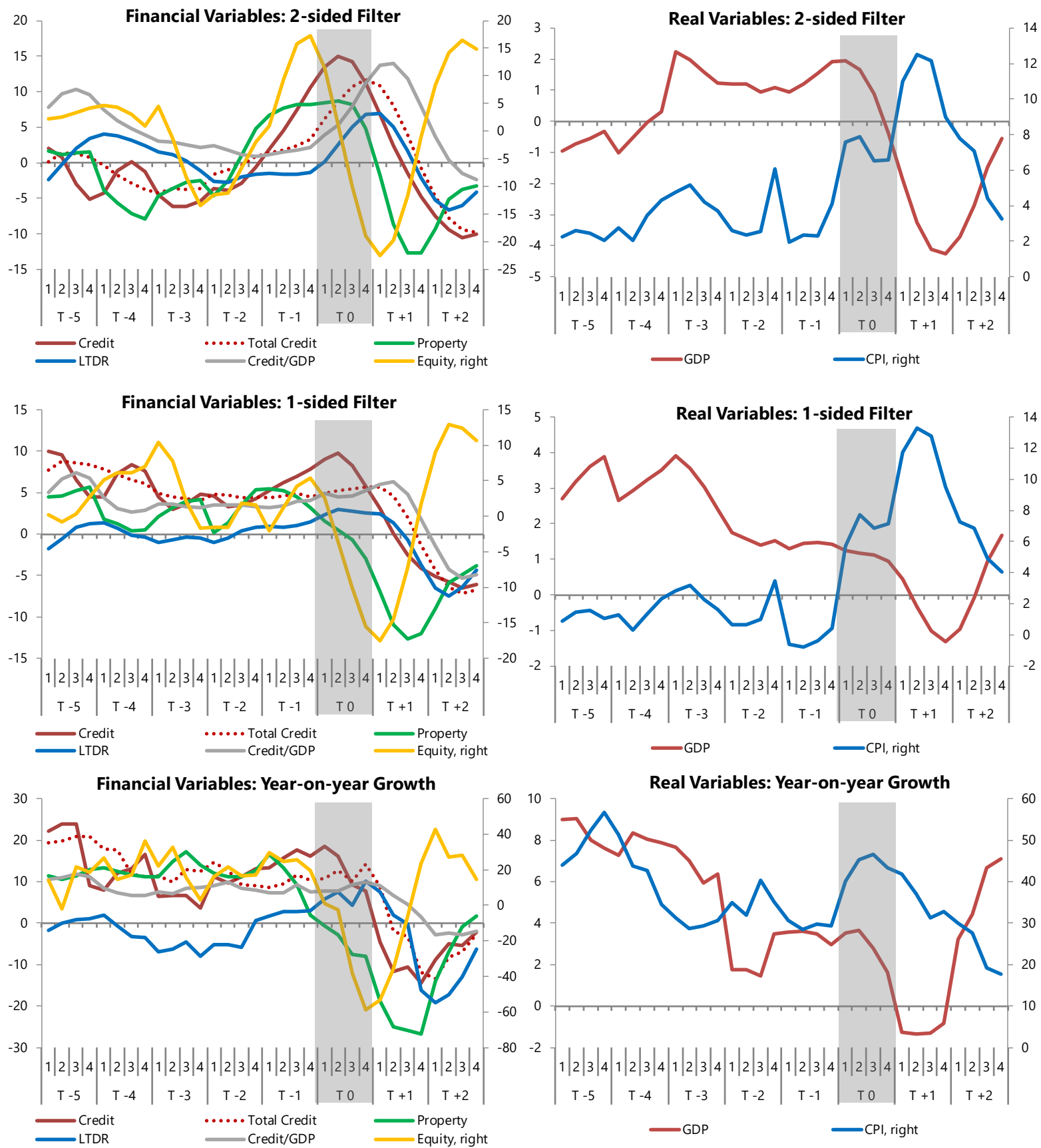

Note: Equity and inflation results for EMs are shown on the right-hand axis. 


\section{B. Early Warning System Model}

To assess the strength of the early warning properties of financial cycles, we employ a nonparametric signal extraction approach similar to Kaminsky et al. (1998). It splits the sample into crisis and non-crisis samples and examines the cumulative distribution functions for the financial cycle gaps in the two groups. Critical threshold values above which the crisis is more likely to occur are chosen for each variable by minimizing the percentage of missed crises (Type I error) and the percentage of false alarms (Type II error).

For each explanatory variable, the chosen threshold minimizes the following loss function:

$$
\begin{aligned}
& \min L\left(x^{*}\right)=\widehat{C D F}^{C}\left(x^{*}\right)+\left(1-\widehat{C D F}^{C}\left(x^{*}\right)\right) \\
& =\frac{1}{n^{C}} \sum_{i=1}^{n^{C}} I_{x_{i}^{C} \leq x^{*}}+\left(1-\frac{1}{n\urcorner^{C}} \sum_{i=1}^{n\urcorner C} I_{x_{i}^{\urcorner} C} \leq x^{*}\right)=\mathrm{T} 1+\mathrm{T} 2
\end{aligned}
$$

Calculations are done variable by variable.

Figure 6 illustrates the methodology. Each variable is ordered such that higher values of the variable indicate a higher probability of a crisis occurring in the following year. For financial cycles, this direction represents financial overheating. Two cumulative distribution functions (CDFs) are generated for the crisis (red) and non-crisis (green) subsamples. A threshold is selected to separate "risky" and "safe" values of the variable, subject to minimizing the sum of Type I and Type II errors. Type I errors are indicated by the height of the CDF for the crisis subsample at the value of the threshold. Type II errors are indicated by one minus the height of the CDF for the non-crisis subsample at the value of the threshold. The loss function is minimized at the threshold value for which the distance between CDFs is greatest.

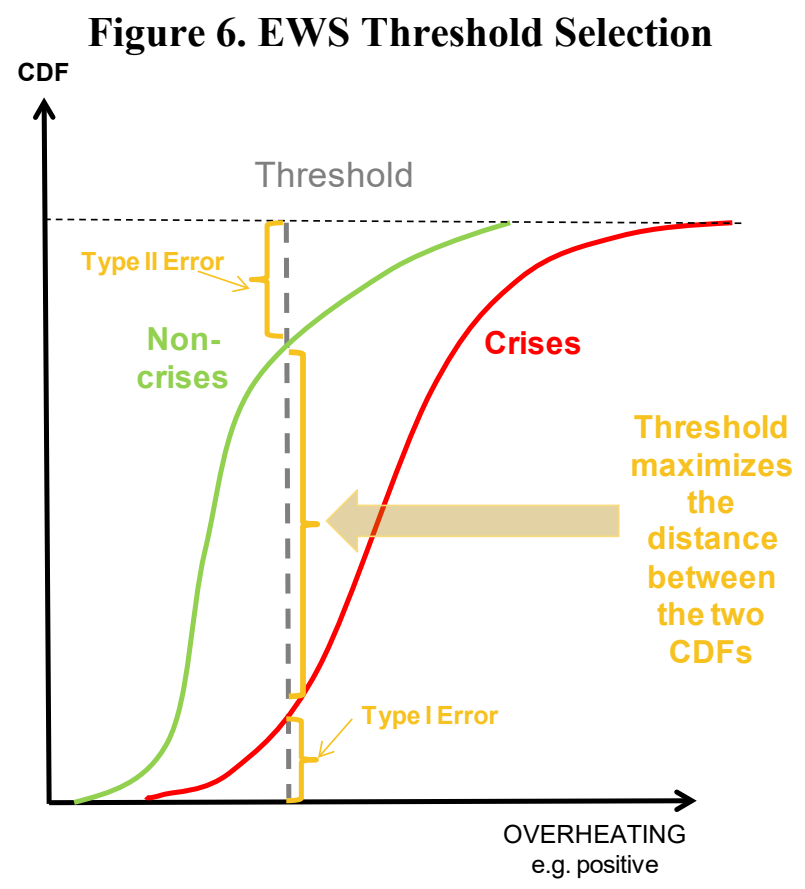


By defining the loss function to be the sum of the percentage of crises missed and the percentage of non-crises falsely flagged as a crisis, we capture the notion that missing a crisis observation is much more costly than issuing a false alarm. For example, if crises are 5 percent of the sample, missing one crisis is as costly as issuing 19 false alarms.

The performance of each variable in terms of forecasting a crisis is assessed via its signal to noise (STN) ratio:

$$
\frac{1-T 1-T 2}{T 1+T 2}
$$

A better early warning indicator will have a higher signal-to-noise ratio. Signal is the share of properly identified crisis and non-crises episodes. Noise is the misidentified cases - i.e. missed crises and false alarms.

How does this approach compare to the now standard method of comparing forecasting power of indicators via the AUROC (Figure 7)? AUROC, or the area under the receiver operating characteristic (ROC) curve, is another non-parametric approach that measures the ability of a model to discriminate between crisis and non-crisis cases. The ROC curve shows the trade-off between the true positive rate and the false positive rate of a signal across different decision thresholds. The ROC curve is from the random classifier curve, which assigns crisis probability via a 50-50 coin flip and is represented by a 45 -degree line. The further away from the ROC curve the better the model is at classifying the variables and the higher will be the AUROC. Thus, an AUROC of 0.5 is the worst possible model when variables are randomly assigned, and an AUROC of 1 is the perfect classifier. An AUROC of 0.8 means that in 80 percent of the cases, the model is correctly assigning the variable's values into the crisis versus non-crisis samples.

Our approach is preferable to AUROC for the following reasons. The AUROC approach compares the combined signaling power of indicators across all possible thresholds; this is represented by the area under the ROC curve. Our approach instead choses a particular loss function and compares the signaling performance of the variables at the best threshold as chosen by the loss function. As seen in Figure 7, the threshold chosen by minimizing the loss function in equation 2 is equivalent to choosing a point under the ROC curve that is furthest away from 45-degree line, i.e. the point where the model is the furthest away from the random choice model. Our approach is preferable for a policy setting where simple and clearcut rules are needed for policy action, including variables that offer the best forecasting power and their associated thresholds that would warrant attention and policy action if breached. This is important particularly for cases where the AUROC for indicator 1 may be higher than that of indicator 2 generally with larger area under the ROC curve, but that under a specific threshold chosen for policy setting, indicator 2 may have better performance with higher ROC curve (for example, in cases where the ROC curves cross). 
Figure 7. EWS Versus AUROC
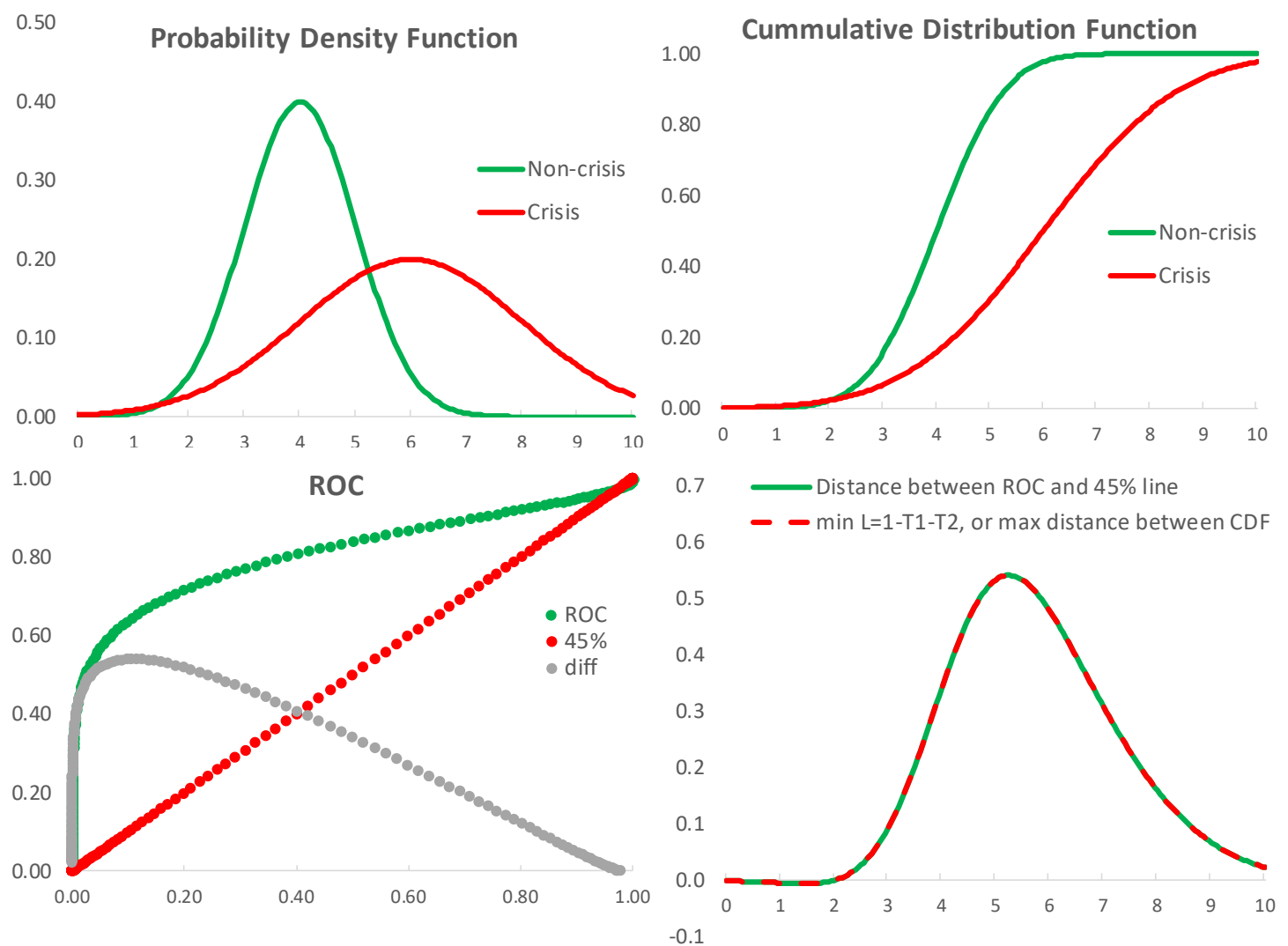

Figures 8, 9 and 10 report the signal-to-noise ratios for two-sided and one-sided filters at different forecast horizons, as well the results for three widely-used financial vulnerability indicators: (i) excess credit growth measure from the Basel Committee on Bank Supervision (BIS credit gap as measured by the deviation from the HP trend with 400,000 smoothing parameter); (ii) year-on-year credit growth rate over a 5-year period based on work of Schularick and Taylor (2012); and (iii) for robustness test, growth in the underlying series. Each data point is the result of a separate estimation. For example, the value of 1.6 for twosided equity price gap in year 1 quarter 2 before the crisis is the STN at the optimal threshold for the equity price gap when the observations in that quarter are split into crisis and noncrisis samples in time 0 .

As expected and discussed earlier in the note, the two-sided filters estimated with the benefit of hindsight have better forecasting power (Figure 8). In advanced markets, stock prices and output gap appear to be the best indicators of overheating, followed by property prices and inflation. LTDR and bank credit tend to have weaker signaling power. In emerging markets, output gap does not have such a strong predictive power as in advanced markets. Instead, the best early warning indicators are property and equity prices and credit in the year before the crisis, credit-to-GDP and property prices five years before the crisis, and output gap and inflation three years before the crisis. In AMs, predictive power is the best in the year before the crisis year and drops as the lag increases, with the exception of equity prices that show a second smaller peak in STN four years before the crisis. The predictive power of BIS credit gap and Schularick measures are mostly in the lower range of the STN estimates. 


\section{Figure 8. Early Warning System Results (2-sided filter)}
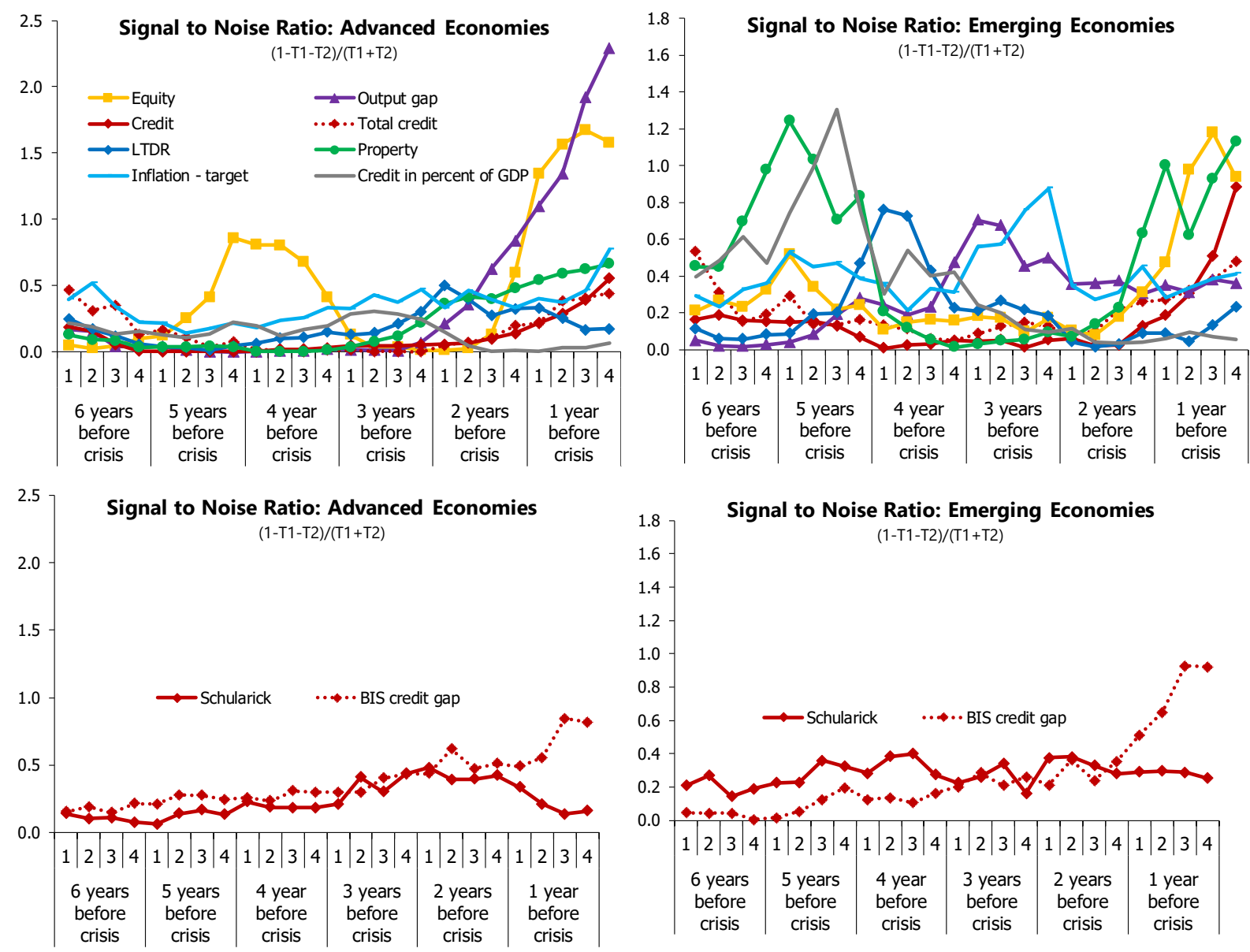


\section{Figure 9. Early Warning System Results (1-sided filter)}
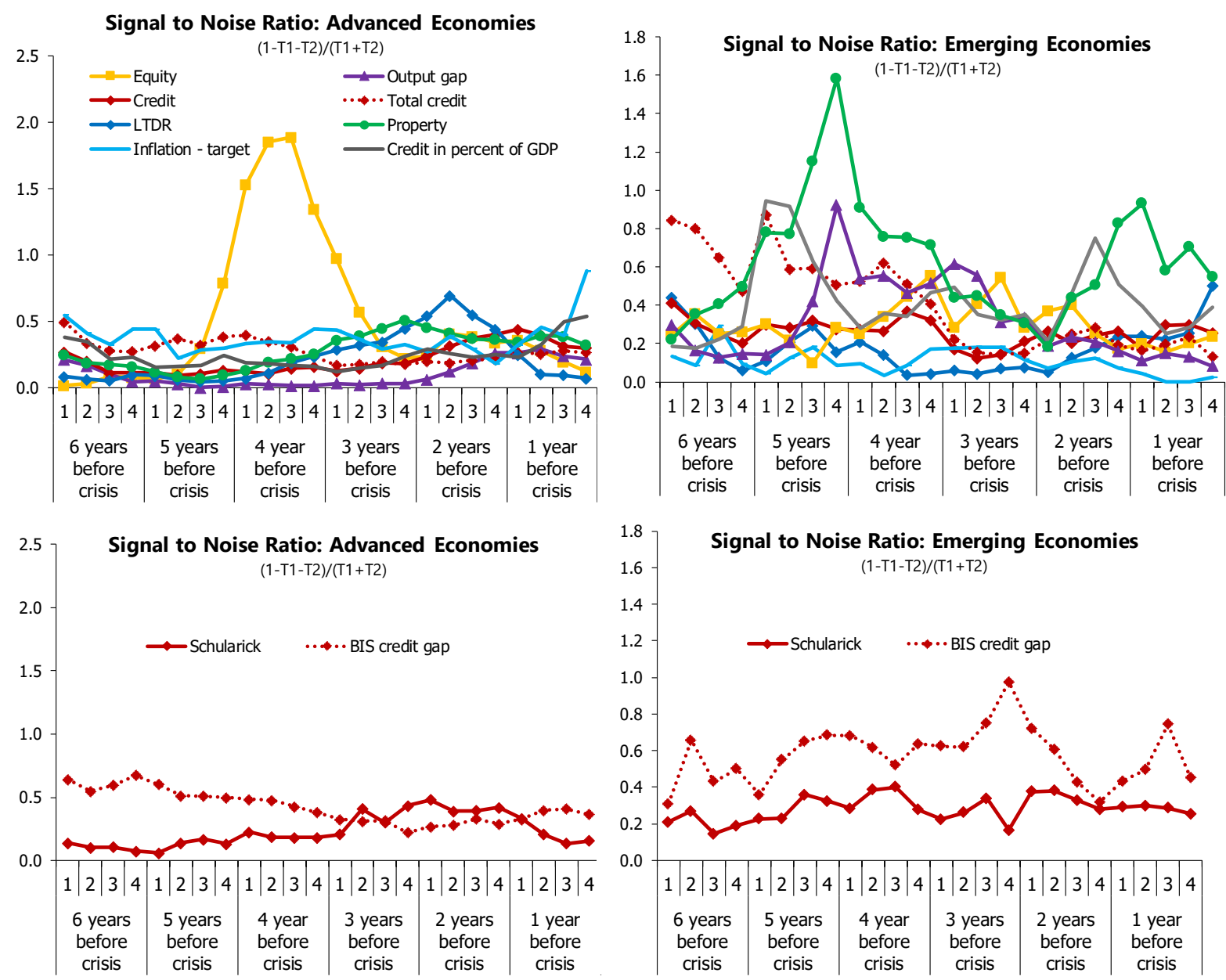

The results for the one-sided filters - and the lower STN estimates - acknowledge the difficulties in making real-time inference based on cyclical deviations (Figure 9). In real-time application of filters, the accuracy of inference is contingent on forecasts - something difficult to achieve ex ante with precision. Not surprisingly, their associated signal-to-noise ratios are generally lower both for financial and real variables. In advanced markets, equity price is the best predictor and its predictive power shifts forward from one year to four years before the crisis. Although the lag time is more drawn out, it remains a useful early warning indicator. The next best indicator is LTDR two years before the crisis, but credit is not a very strong indicator. In emerging markets, property price is the best indicator one year before the crisis and even more so four to five years before the crisis. Credit-to-GDP is the second-best predictor two and five years before the crisis. The predictive power of BIS credit gap and Schularick measures is mostly in the lower range of the STN estimates, except for BIS credit gap three years before the crisis in emerging markets.

For growth rates, the signal-to-noise ratio is generally on par with the one-sided filters, with a few exceptions (Figure 10). The growth rate of equity prices has the best predictive power in advanced markets, offering multiple signals during the four to five years period and two 
years before the crisis, consistent with the results from the two-sided filter. Meanwhile, GDP growth is less useful. Property price growth is also useful three years before the crisis. In emerging markets, GDP growth is the best indicator four-five years before the banking crisis, followed by the growth of equity prices three years before the crisis, credit-to-GDP two years before the crisis, and property price growth throughout the sample.

The results of the AUROC estimations are quite comparable with our STN estimations (Appendix 6). With two-sided filters, for advanced markets, AUROC gives a similar finding that equity price and output gap are excellent indicators, with AUROCs above 0.8 in the year before the crisis. Other indicators give a sub-par performance, with AUROC below 0.7. For emerging markets, only equity and property prices, credit and BIS credit gap show an AUROC above 0.7 in the year before the crisis.

\section{Figure 10. Early Warning System Results (Growth)}
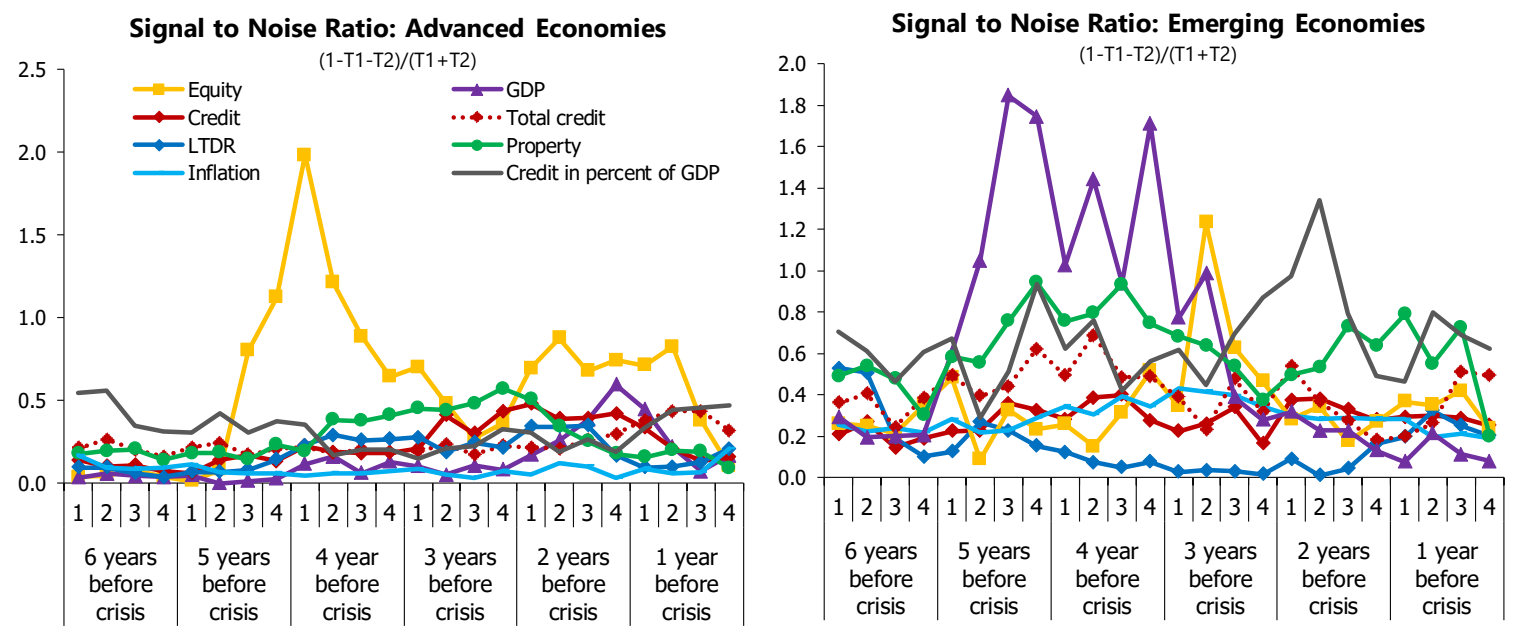

\section{Logit Regressions}

As another robustness check to EWS, we estimate the following regression equation:

$$
\operatorname{Logit}\left(P_{i, t}\right)=\beta_{0, t}+\beta_{1}(L) \text { Cycl. Deviations } s_{i, t}+\beta_{2}(L) X_{i, t}+\varepsilon_{i, t}
$$

where the probability of banking crisis is dependent on the cyclical deviation of financial variables and additional controls, including credit spread, VIX, cyclicallyadjusted primary balance, Chinn-Ito Index, and REER. $L$ is the lag operator; the lag polynominal $\beta_{1}(L)$ contains lag orders from 1 to 16 and is the main object of study. The goal here is to investigate whether movements of credit and asset prices before the onset of banking crisis matter. Lags are staggered in separate regressions to minimize autocorrelation, e.g. $L(1,5,9,13)$ is a separate regression from $L(2,6,10,14), L(3,7,11,15)$, and $L(4,8,12,16)$. The specification includes random effects, while country fixed effects were not significant. Because of limited data, particularly for many of the control variables, this exercise only considers advanced economies. 
For cyclical deviations derived with two-sided filters, logit regressions results are mostly similar to EWS, with credit booms over 1 year prior to the crisis, property booms over previous 2 years, and sharp changes in equity prices within the previous 2 years useful in predicting banking crises (Table 3 ). By contrast, LTDR offers longer lead, with significant loan expansion in the previous $2^{1} \frac{1}{2}$ years useful in predicting banking crises. That said, introducing "real economy" variables such as output gap and inflation gap strips away the significance of credit measures, though property price, equity price and LTDR remain significant (Table 4).

A striking finding is the nonlinear nature of crisis probabilities (Figure 11). A modest increase of 0.3 percentage points of excess home prices relative to trend beyond the $1 \%$ level raises crisis probability sizably. Specifically, the probability of crisis increases by 18 percentage points, from about $12 \%$ to $30 \%$ if excess house price rises from $0.9 \%$ to $1.2 \%$. Meanwhile, underscoring the predictive power of equity prices for banking crisis, even a modest increase in excess valuation relative to trend pushes up the probability of banking crisis. At $4 \%$ overvaluation - based on our metrics - the probability of banking crisis reaches near certainty. By contrast, while both bank credit and LTDR exhibit similar non-linearity, the cumulative probability remains modest. For bank credit, the crisis probability reaches no more than $12 \%$ with a $1.5 \%$ deviation. For LTDR, crisis probability was no more than $2 \%$ with a deviation of $1.8 \%$.

Compared to two-sided filters, the predicative power of one-sided filters gets shifted forward, and particularly dramatically for equity prices, which moved from within one year to four years (Table 4). While this allows for earlier warning, it also underscores the difficulty of predicting the timing of crises. A "horserace" of financial variables suggests that property and equity prices remain the most useful indicators, particularly with one-sided filters for real time analysis. Robustness test using detrended financial variables - bank credit, property prices and equity prices - offer qualitatively similar results for two-sided filters. 
Table 3. Probability of Banking Crisis (AM; 2-sided filters)

\begin{tabular}{|c|c|c|c|c|}
\hline Independent Variable & Bank Credit & Property Prices & Equity Prices & LTDR \\
\hline & $\begin{array}{c}\text { Reg } 1 \\
\text { coef/se }\end{array}$ & $\begin{array}{c}\operatorname{Reg} 2 \\
\text { coef/se }\end{array}$ & $\begin{array}{c}\text { Reg } 3 \\
\text { coef/se }\end{array}$ & $\begin{array}{c}\text { Reg } 4 \\
\text { coef/se }\end{array}$ \\
\hline L. & $\begin{array}{l}4.58^{\star \star \star} \\
(5.92)\end{array}$ & $\begin{array}{c}25.28^{\star * \star} \\
(7.89)\end{array}$ & $\begin{array}{l}-1.72 \\
(16.7)\end{array}$ & $\begin{array}{c}3.1 \\
(4.01)\end{array}$ \\
\hline L2. & $\begin{array}{c}9.07^{\star * *} \\
(5.04)\end{array}$ & $\begin{array}{c}25.86^{\star \star \star} \\
(6.90)\end{array}$ & $\begin{array}{l}37.55^{\star *} \\
(14.66)\end{array}$ & $\begin{array}{l}3.55^{\star} \\
(2.11)\end{array}$ \\
\hline L3. & $\begin{array}{c}11.89 * * * \\
(4.52)\end{array}$ & $\begin{array}{c}22.93^{\star * \star} \\
(7.00)\end{array}$ & $\begin{array}{c}66.76^{\star * *} \\
(14.10)\end{array}$ & $\begin{array}{c}3.51 \\
(2.16)\end{array}$ \\
\hline L4. & $\begin{array}{c}12.60 * * * \\
(3.80)\end{array}$ & $\begin{array}{l}19.76^{\star \star} \\
(8.72)\end{array}$ & $\begin{array}{c}82.13^{\star * \star} \\
(14.48)\end{array}$ & $\begin{array}{c}3.43 \\
(2.35)\end{array}$ \\
\hline L5. & $\begin{array}{c}12.33^{* * *} \\
(3.06)\end{array}$ & $\begin{array}{l}19.07 * * \\
(9.57)\end{array}$ & $\begin{array}{c}81.47^{\star * \star} \\
(16.03)\end{array}$ & $\begin{array}{c}4.33 \\
(3.85)\end{array}$ \\
\hline L6. & $\begin{array}{c}11.74^{\star * \star} \\
(3.08)\end{array}$ & $\begin{array}{l}24.07^{\star \star} \\
(10.82)\end{array}$ & $\begin{array}{c}82.70 * * * \\
(15.00)\end{array}$ & $\begin{array}{c}5.29^{* * *} \\
(1.76)\end{array}$ \\
\hline L7. & $\begin{array}{c}12.40 * * \star \\
(4.07)\end{array}$ & $\begin{array}{c}31.63^{\star \star \star} \\
(10.70)\end{array}$ & $\begin{array}{c}65.00 * * * \\
(14.17)\end{array}$ & $\begin{array}{c}6.21^{\star \star \star} \\
(1.51)\end{array}$ \\
\hline L8. & $\begin{array}{c}13.75^{\star * \star} \\
(4.55)\end{array}$ & $\begin{array}{c}37.05^{\star \star \star} \\
(9.36)\end{array}$ & $\begin{array}{l}34.30 * * \\
(13.37)\end{array}$ & $\begin{array}{c}6.84^{\star \star *} \\
(1.67)\end{array}$ \\
\hline L9. & $\begin{array}{c}9.54^{\star \star \star} \\
(3.88)\end{array}$ & $\begin{array}{c}42.58^{\star \star \star} \\
(9.46)\end{array}$ & $\begin{array}{c}-8.11 \\
(17.95)\end{array}$ & $\begin{array}{l}7.12^{\star \star \star} \\
(2.67)\end{array}$ \\
\hline L10. & $\begin{array}{c}7.18^{\star \star \star} \\
(3.57)\end{array}$ & $\begin{array}{c}38.32^{\star \star \star} \\
(9.33)\end{array}$ & $\begin{array}{c}19.73 \\
(15.40)\end{array}$ & $\begin{array}{c}7.58^{\star \star \star} \\
(2.12)\end{array}$ \\
\hline L11. & $\begin{array}{l}3.09 * * * \\
(3.62)\end{array}$ & $\begin{array}{c}28.76^{\star * \star} \\
(8.71)\end{array}$ & $\begin{array}{c}41.60 * * * \\
(14.31)\end{array}$ & $\begin{array}{c}7.30^{\star * *} \\
(1.74)\end{array}$ \\
\hline L12. & $\begin{array}{c}-1.67^{\star \star \star} \\
(4.31)\end{array}$ & $\begin{array}{c}17.46^{\star \star} \\
(7.06)\end{array}$ & $\begin{array}{c}55.78^{\star * *} \\
(14.22)\end{array}$ & $\begin{array}{c}6.50^{\star * *} \\
(1.52)\end{array}$ \\
\hline L13. & $\begin{array}{c}-0.05^{\star \star *} \\
(3.10)\end{array}$ & $\begin{array}{l}15.00 * * \\
(7.04)\end{array}$ & $\begin{array}{c}58.35^{\star * *} \\
(13.79)\end{array}$ & $\begin{array}{c}5.16 \\
(3.25)\end{array}$ \\
\hline L14. & $\begin{array}{c}-0.53^{\star \star *} \\
(3.06)\end{array}$ & $\begin{array}{l}10.08 \\
(6.99)\end{array}$ & $\begin{array}{c}64.36^{\star * \star} \\
(13.78)\end{array}$ & $\begin{array}{c}4.44^{\star * *} \\
(1.66)\end{array}$ \\
\hline L15. & $\begin{array}{c}-0.70^{\star \star \star} \\
(3.47)\end{array}$ & $\begin{array}{c}7.54 \\
(7.48)\end{array}$ & $\begin{array}{l}55.42^{* * *} \\
(13.90)\end{array}$ & $\begin{array}{l}3.92^{* *} \\
(1.63)\end{array}$ \\
\hline L16. & $\begin{array}{c}-1.23^{\star \star *} \\
(3.47)\end{array}$ & $\begin{array}{c}6.67 \\
(8.12)\end{array}$ & $\begin{array}{l}34.30 * * \\
(14.41)\end{array}$ & $\begin{array}{l}3.41^{\star *} \\
(1.49)\end{array}$ \\
\hline _cons ${ }^{1}$ & $\begin{array}{c}-5.29 * \star \star \\
(0.20) \\
\end{array}$ & $\begin{array}{c}-5.22^{\star \star *} \\
(0.23) \\
\end{array}$ & $\begin{array}{c}-5.80^{\star \star \star} \\
(0.27) \\
\end{array}$ & $\begin{array}{c}-5.43^{\star \star \star} \\
(0.22) \\
\end{array}$ \\
\hline Number of observations $^{2}$ & 4,833 & 3,630 & 3,510 & 5,014 \\
\hline Number of groups ${ }^{2}$ & 33 & 33 & 33 & 33 \\
\hline $\begin{array}{l}\text { Sum of lag coefficients } \\
\text { s.e. }\end{array}$ & $\begin{array}{l}26.40^{\star * *} \\
(5.59)\end{array}$ & $\begin{array}{c}101.92^{* * *} \\
(26.61)\end{array}$ & $\begin{array}{l}129.99^{* *} \\
(53.59)\end{array}$ & $\begin{array}{l}17.71^{* *} \\
(5.87)\end{array}$ \\
\hline Pseudo $R^{2}$ Note 3 & 0.0138 & 0.0481 & 0.176 & 0.0232 \\
\hline
\end{tabular}

Note: ${ }^{* *} p<0.01,{ }^{* *} p<0.05,{ }^{*} p, 0.1$. Robust standard errors in parenthesis.

Note 1: Average of contant terms

Note 2: Lowest number of observations

Note 3: Lowest pseudo $\mathrm{R}^{2}$ 


\section{Table 4. Probability of Banking Crisis (AM; 1- and 2-sided filters with controls)}

\section{Predicting Banking Crisis Based on Financial Variable Movements (A Panel Logit Approach)}

Dependent Variable: Laeven \& Valencia banking crises, binary variable, with 1 indicating first quarter of the year during which crises took place.

Controls: Credit spread, cyclically-adjusted primary balance, Chinn-Ito Index, and VIX. Results qualitatively the same.

\begin{tabular}{|c|c|c|c|c|c|c|c|c|c|c|}
\hline & Reg 1 & $\operatorname{Reg} 2$ & $\operatorname{Reg} 3$ & $\operatorname{Reg} 4$ & $\operatorname{Reg} 5$ & $\operatorname{Reg} 6$ & $\operatorname{Reg} 7$ & $\operatorname{Reg} 8$ & $\operatorname{Reg} 9$ & $\operatorname{Reg} 10$ \\
\hline Explanatory variable & $\begin{array}{l}\text { One- } \\
\text { sided } \\
\text { gap }\end{array}$ & $\begin{array}{l}\text { Two- } \\
\text { sided } \\
\text { gap }\end{array}$ & $\begin{array}{l}\text { One- } \\
\text { sided } \\
\text { gap }\end{array}$ & $\begin{array}{l}\text { Two- } \\
\text { sided } \\
\text { gap }\end{array}$ & $\begin{array}{l}\text { One- } \\
\text { sided } \\
\text { gap }\end{array}$ & $\begin{array}{l}\text { Two- } \\
\text { sided } \\
\text { gap }\end{array}$ & $\begin{array}{l}\text { One- } \\
\text { sided } \\
\text { gap }\end{array}$ & $\begin{array}{l}\text { Two- } \\
\text { sided } \\
\text { gap }\end{array}$ & $\begin{array}{l}\text { One- } \\
\text { sided } \\
\text { gap }\end{array}$ & $\begin{array}{l}\text { Two- } \\
\text { sided } \\
\text { gap }\end{array}$ \\
\hline $\begin{array}{l}\text { Lead time to crises } \\
\text { (quarters) }\end{array}$ & 4 & 3 & 9 & 9 & 16 & 3 & 8 & 8 & varies & varies \\
\hline Bank credit & $\begin{array}{c}0.05 \\
(0.03)\end{array}$ & $\begin{array}{c}0.00 \\
(0.03)\end{array}$ & & & & & & & $\begin{array}{c}0.17^{* * *} \\
(0.03)\end{array}$ & $\begin{array}{l}-0.04 * \\
(0.02)\end{array}$ \\
\hline Property price & & & $\begin{array}{c}0.17^{* * *} \\
(0.04)\end{array}$ & $\begin{array}{c}0.13^{* * *} \\
(0.03)\end{array}$ & & & & & $\begin{array}{c}0.28^{* * *} \\
(0.05)\end{array}$ & $\begin{array}{l}0.07^{*} \\
(0.03)\end{array}$ \\
\hline Equity prices & & & & & $\begin{array}{c}0.16^{* * *} \\
(0.02)\end{array}$ & $\begin{array}{c}0.16^{* * *} \\
(0.02)\end{array}$ & & & $\begin{array}{c}0.19 * * * \\
(0.02)\end{array}$ & $\begin{array}{c}0.12^{* * *} \\
(0.01)\end{array}$ \\
\hline LTDR & & & & & & & $\begin{array}{c}0.20 * * * \\
(0.04)\end{array}$ & $\begin{array}{c}0.21 * * * \\
(0.04)\end{array}$ & $\begin{array}{l}-0.03 \\
(0.05)\end{array}$ & $\begin{array}{c}0.20^{* * *} \\
(0.05)\end{array}$ \\
\hline Output gap ${ }^{1 /}$ & $\begin{array}{l}0.14^{* *} \\
(0.06)\end{array}$ & $\begin{array}{c}0.52^{* * *} \\
(0.06)\end{array}$ & $\begin{array}{l}-0.04 \\
(0.09)\end{array}$ & $\begin{array}{c}0.00 \\
(0.06)\end{array}$ & $\begin{array}{l}0.12 * \\
(0.07)\end{array}$ & $\begin{array}{c}0.36^{* * *} \\
(0.09)\end{array}$ & $\begin{array}{c}0.03 \\
(0.08)\end{array}$ & $\begin{array}{l}-0.05 \\
(0.07)\end{array}$ & $\begin{array}{l}-0.30 * * \\
(0.13)\end{array}$ & $\begin{array}{c}0.30^{* * *} \\
(0.10)\end{array}$ \\
\hline Inflation from target ${ }^{1}$ & $\begin{array}{c}-0.14^{* * *} \\
(0.02)\end{array}$ & $\begin{array}{c}-0.08^{* * *} \\
(0.02)\end{array}$ & $\begin{array}{c}0.09 * * * \\
(0.02)\end{array}$ & $\begin{array}{c}0.16^{* * *} \\
(0.03)\end{array}$ & $\begin{array}{c}0.02 \\
(0.01)\end{array}$ & $\begin{array}{c}-0.09 * * * \\
(0.02)\end{array}$ & $\begin{array}{c}0.06^{* * *} \\
(0.02)\end{array}$ & $\begin{array}{c}0.02 \\
(0.02)\end{array}$ & $\begin{array}{c}0.10^{* * *} \\
(0.03)\end{array}$ & $\begin{array}{c}0.04 \\
(0.04)\end{array}$ \\
\hline Constant & $\begin{array}{c}-3.79 * * * \\
(0.17) \\
\end{array}$ & $\begin{array}{c}-4.33^{* * *} \\
(0.15) \\
\end{array}$ & $\begin{array}{c}-3.75^{* * *} \\
(0.17) \\
\end{array}$ & $\begin{array}{c}-4.49 * * * \\
(0.16) \\
\end{array}$ & $\begin{array}{c}-4.63^{* * *} \\
(0.22) \\
\end{array}$ & $\begin{array}{c}-5.58^{* * *} \\
(0.28) \\
\end{array}$ & $\begin{array}{c}-3.76^{* * *} \\
(0.14) \\
\end{array}$ & $\begin{array}{c}-4.79 * * * \\
(0.16) \\
\end{array}$ & $\begin{array}{c}-5.11 * * * \\
(0.31) \\
\end{array}$ & $\begin{array}{c}-5.54^{* * *} \\
(0.24) \\
\end{array}$ \\
\hline Number of obs. & 3,123 & 3,157 & 2,761 & 2,761 & 2,790 & 2,825 & 3,021 & 3,021 & 2,303 & 2385 \\
\hline Pseudo $R^{2}$ & 0.10 & 0.25 & 0.13 & 0.30 & 0.24 & 0.45 & 0.09 & 0.30 & 0.40 & 0.47 \\
\hline
\end{tabular}

Note: $* * * p<0.01, * * p<0.05, * p<0.1 ;$ Robust standard errors in parentheses.

Note 1: A lag structure of up to 16 quartes is used.

Results presented for $\operatorname{Reg} \mathbf{9}$ and $\operatorname{Reg} \mathbf{1 0}$ are from 8 quarters ahead of crises, when the coefficient in focus is largest. 


\section{Figure 11. Logit Summary - Unconditional Probability of Banking Crisis}
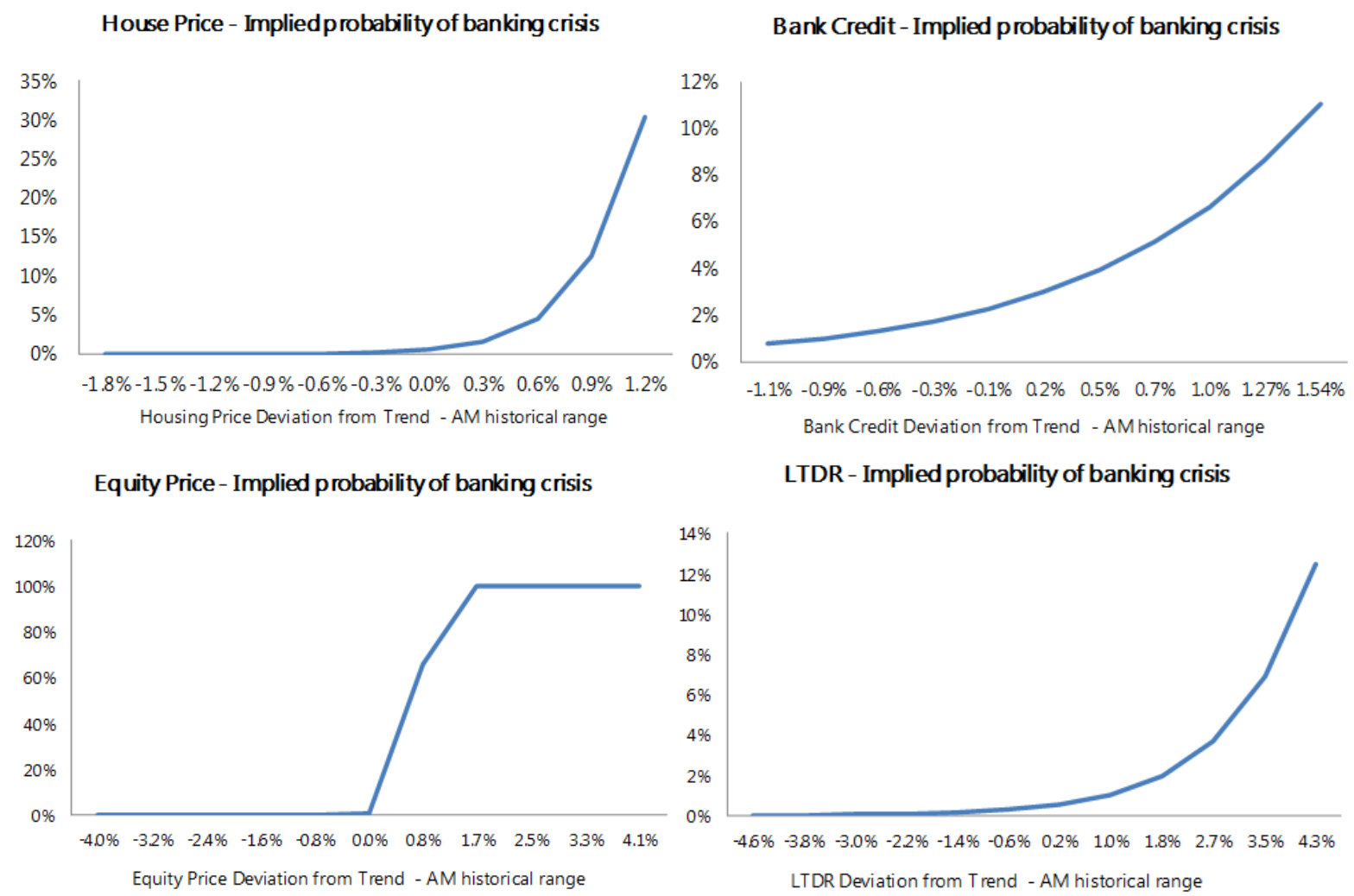

\section{Why Is CREDIT NOT THE BEST EARLY WARNING INDICATOR IN AM?}

One surprising finding is the lackluster predictive power of credit. This finding is at odds with the literature on the role of credit in financial instability.

Indeed, credit - and more specifically, the level of aggregate debt - plays a crucial role in financial stability. A rich body of work has documented the role of sharp credit increases in financial crises (Friedman, 1986, Gourinchas and Obstfeld, 2012, Schularick and Taylor, 2012). Missing from these analyses is the linkage between credit and banking crisis through the collateral channel, as seen during the Global Financial Crisis. The role of collateralized borrowing and endogenous credit creation in amplifying financial stability risks have been studied extensively (Bernanke and Gertler, 1989, Kiyotaki and Moore, 1997, and Bernanke et. al, 1999, Geanakoplos, 2010). Specifically, while excessive credit growth is a proximate cause of banking crisis, it is the correction in asset prices - the valuation of collaterals - that can trigger the turn in credit cycles and correspondingly, the ensuing balance sheet stress for lenders and borrowers.

The behavior of asset prices during banking crises reinforce its role as an early warning indicator. Historically, banking crises have often followed asset price booms and busts. The Great Depression began with the 1929 stock market crash in the United States, followed by bank runs and subsequent bank failures. From 1930 to 1933, more than 1,000 U.S. banks closed a year. Similar patterns are seen throughout economic history, starting with the Dutch 
Tulipmania and the South Sea bubble in England to the more recent examples of Japan stock market bust in 1990 and its Lost Decade, Nordic Banking Crises in 1991, Asian Financial Crisis in 1997, and most recently, the Global Financial Crisis in 2007-08. Indeed, Greenwood et al. (2020) show that while predictive power of credit for the onset of future crisis is modest, the degree of predictability rises substantially when they focus on large credit expansions that are accompanied by asset price booms.

Historical precedents underscore the cyclical characteristics uncovered in our analysis of equity cycles and equity's predictive power - equity cycles tend to peak before credit cycles, and credit collapse lag stock market crash. Moreover, as a practical matter for policy makers, as shown earlier, cycles in equity prices tend to have greater amplitude and can be easier to identify in the data, improving their signaling power. Even in real time estimations with onesided filters, equity prices retain their signaling power, unlike credit. In short, the stock market bubble is a sign, rather than a cause, of the banking crisis; it is a tried-and-true yardstick of a financial system that is flushed with liquidity, is overheating, and is taking on unnecessary risks.

What explains the difference between advanced and emerging economies? Why does credit retain a better signaling power in EM? One possible explanation is that in emerging markets, credit continues to be largely intermediated by banks. As a result, credit has a better signaling power about the health of EM banking systems. As shown in Figure 13, in the last decade, credit on average made up 52 percent of the bank asset portfolio, compared to the 41 percent in advanced economies. Another possible explanation is that banking systems in emerging markets are more vulnerable to the swings in capital inflows. As a result, domestic credit itself tends to exhibit bubble-like behavior. This was the case for example in Eastern Europe in the late 1990s and the first half of 2000s when transition economies attracted massive capital inflows, leading to a boom in bank credit, asset prices, and domestic demand.

\section{Figure 12. Credit in Percent of Total Assets}

(Average, 2010-2019)

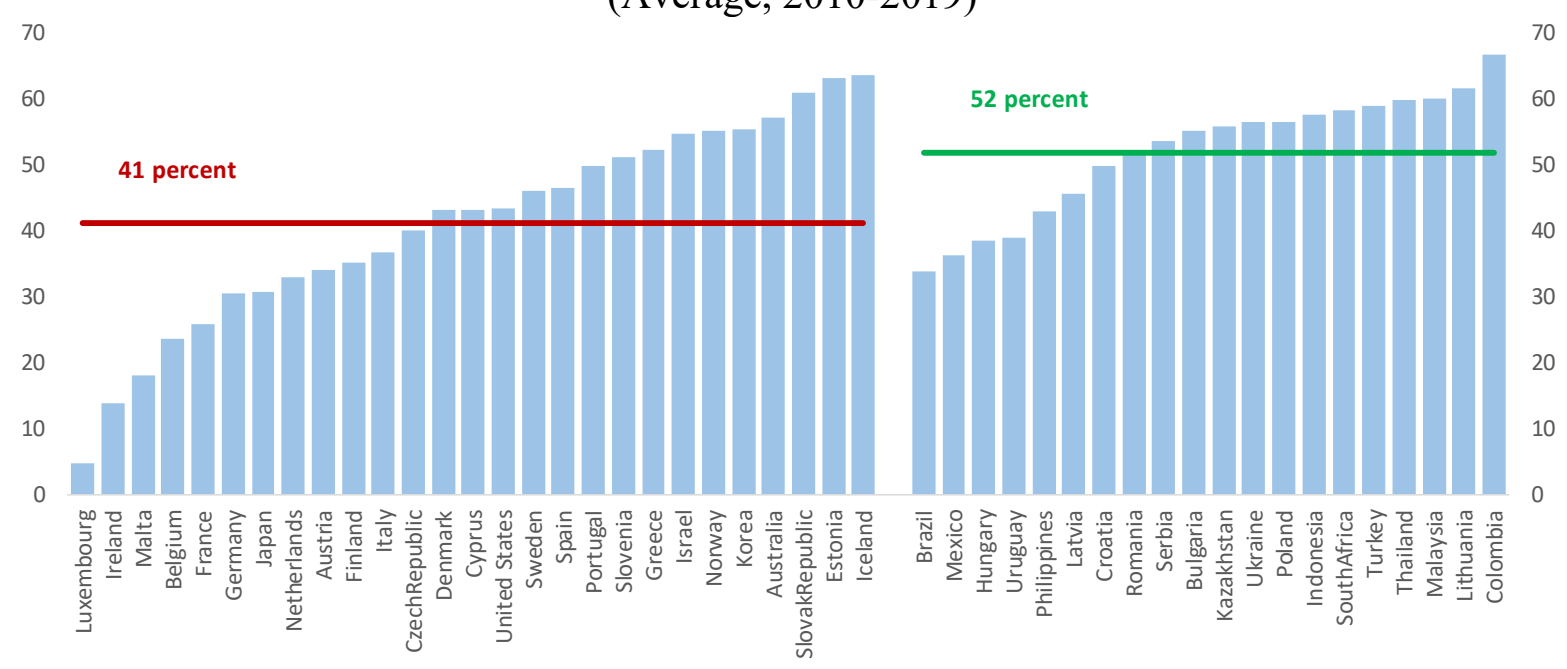

Source: Author calculations based on IFS and FSI. 


\section{OVERHEATING INDEX}

To illustrate how the results in this paper could be applied, we construct an overheating index, based on the best leading indicators for the two income groups according to the EWS. For advanced economies, these are equity prices and output gap, and for emerging economies, these are equity and property prices and credit. We choose not to use GDP growth in emerging markets as an additional indicator, despite its good signaling power, because unlike with output gap, it would be controversial, although perhaps reasonable, to base financial regulation on excessive economic growth. Of course, central banks or the financial regulatory agencies might want to track a broader or different set of financial indicators and at higher frequency if available, based on country-specific circumstances.

To construct an overheating index, we integrate analyses presented in this paper. First, we estimate financial cycles and their associated cyclical gaps with a one-sided filter to proxy as much as possible the challenges of policy making in real time. Vulnerability thresholds are set at the average levels for financial cycles estimated with two-sided filters in the year before the crisis, when financial cycles have the best predictive power (Table 5). Each country is assigned a crisis warning flag of 1 for each variable that breaches the threshold, and 0 otherwise. Crisis flags are aggregated into an overheating index $(O I)$, giving higher weight to the variables with better signal extraction power. More specifically, the weights are set equal to 1 such that Type I and Type II errors are normalized to sum to one. A higher weight indicates that the variable is more effective in distinguishing between crises and noncrisis samples. As a result, we get two types of overheating indices, one for the EM sample and one for the AM sample:

$$
\begin{aligned}
& O I_{i, t}^{E M}=w_{1} I_{i, t}^{\text {credit }}+w_{2} I_{i, t}^{\text {equity }}+w_{2} I_{i, t}^{\text {property }} \\
& O I_{i, t}^{A M}=w_{1} I_{i, t}^{\text {equity }}+w_{2} I_{i, t}^{G D P}
\end{aligned}
$$

where $I_{i, t}^{x}=\left\{\begin{array}{l}1, \text { if financial cycle gap for variable } \mathrm{x} \text { breaches its threshold } \\ 0, \text { if financial cycle gap for variable } \mathrm{x} \text { does not breach its threshold }\end{array}\right.$

Table 5. Thresholds and Weights (Average of the four quarters before the crisis year)

\begin{tabular}{lccc}
\hline & Threshold & Weight & $\begin{array}{c}\text { Norm. } \\
\text { weight }\end{array}$ \\
\hline Credit & \multicolumn{3}{c}{ Emerging Markets } \\
Equity & 2.9 & 0.3 & 24.2 \\
Property & 10.3 & 0.5 & 37.3 \\
\multicolumn{4}{c}{ Advanced Markets } \\
Equity & 7.5 & 0.5 & 38.5 \\
GDP & \multicolumn{4}{c}{0.6} & 49.7 \\
& 6.7 & 0.6 & 50.3 \\
\hline
\end{tabular}

Threshold is measured as percent deviation from the trend. Weight = 1 - Type I error (share of missed crises) - Type II error (share of false alarms). 
As expected, the resulting indices tend to signal overheating in the years preceding banking crises. Focusing on the average behavior of the index in the crisis group (Figure 13), we see that the indices clearly go up in the years before the crisis, both for advanced and emerging markets. The indices tend to correctly flag between 60 to 65 percent of the banking crises, going up from about 50 percent five years before the crisis to 80 percent in one year before the crisis (Figure 14).

The results are confirmed with country specific examples (Figure 15). Overheating was evident in Sweden, Norway, and Finland in the years preceding the Nordic banking crisis, when credit deregulation led to a loosening of lending standards and resulted in a credit and asset price boom. A similar pattern is seen in Mexico and Colombia before their banking crises in 1981 and 1982, respectively, when the Latin American debt crisis materialized following years of excessive lending by U.S. banks. The index also captured overheating in Asia - i.e. Malaysia, Philippines, and Thailand - up to five years before the Asian Financial Crisis. It also offered warnings in large advanced economies such as United States and United Kingdom, in smaller advanced economies such as Iceland, Ireland, and Greece, and in emerging economies such as Latvia, Kazakhstan, and Ukraine before the Global Financial Crisis.

Figure 13. Overheating Index - Behavior around Crisis Episode
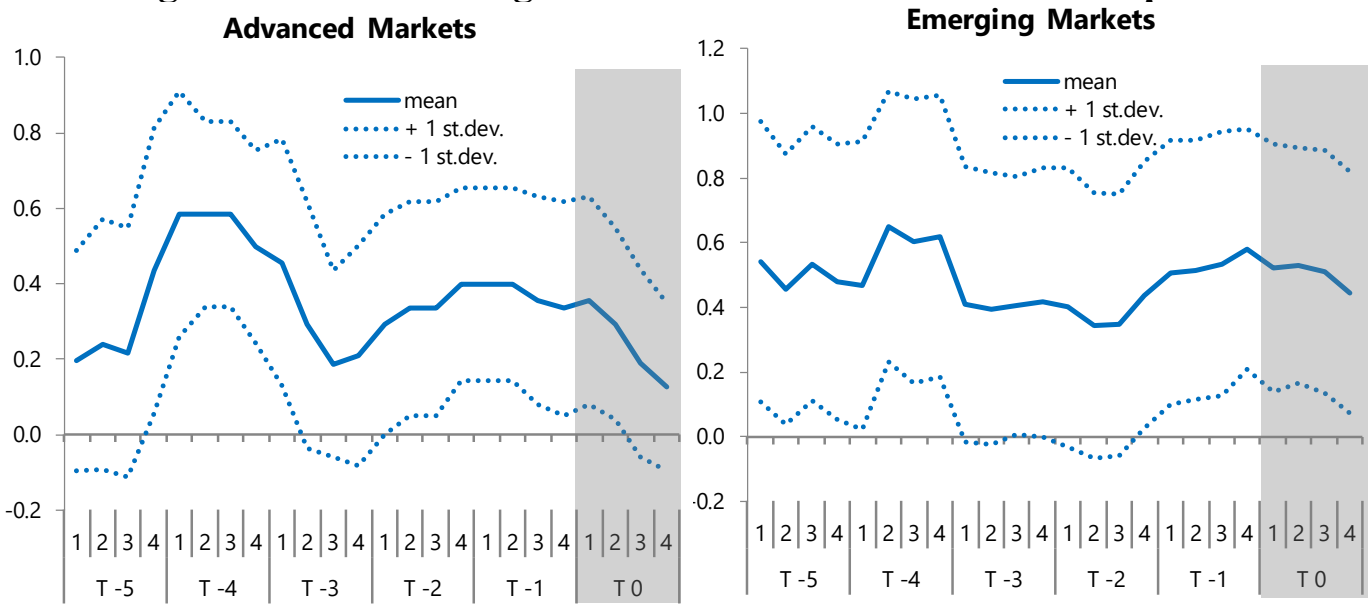

Figure 14. Overheating Index - Percent of Crises Flagged

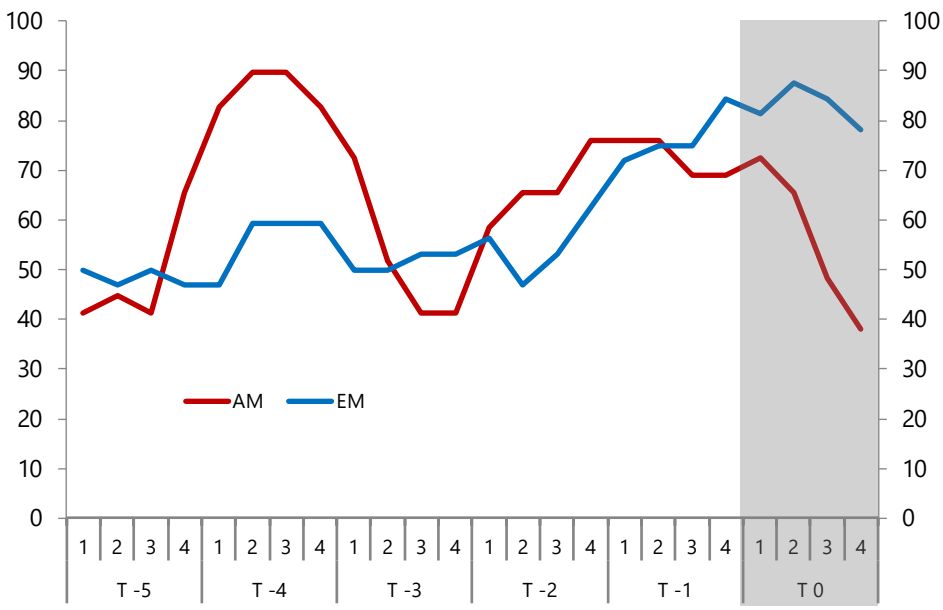


Figure 15. Overheating Index - Country Examples
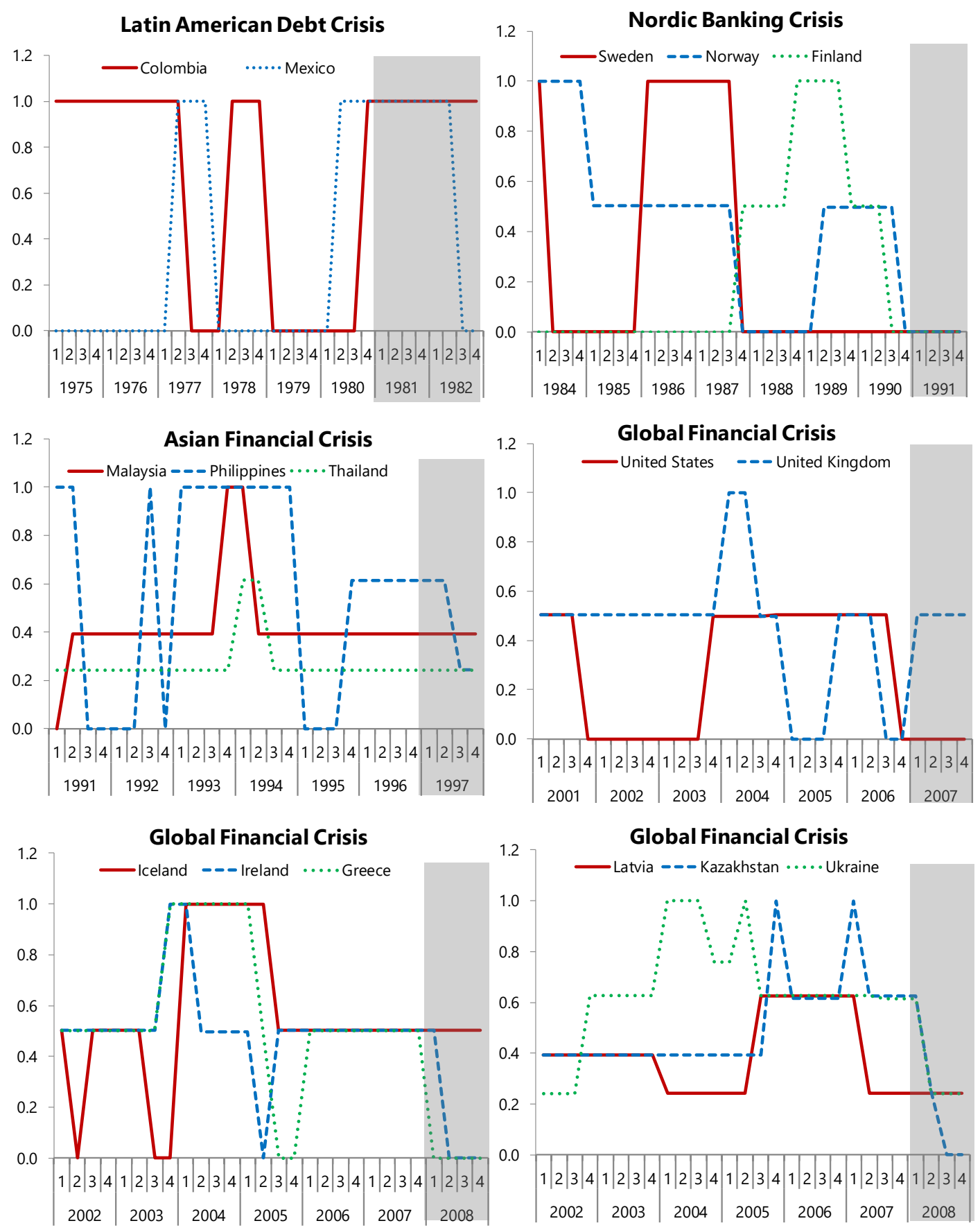
A natural question for this kind of estimation is the out-of-sample fit. The proper out-ofsample forecast is difficult to do without undermining the quality of the main estimations, given the limited number of banking crises in our sample. Instead, we do a simple test by applying our estimations to the 2018 update of the Laeven and Valencia database. The database update adds two additional crises to our estimation: Cyprus in 2011 and Ukraine in 2014. While we do not use these data to estimate the critical thresholds, the index picks up overheating in both of these countries years before their crises (Figure 16).

What matters in these country examples is not so much the shape of the index curve, but the fact that overheating signs are present in the years before the onset of crises. Even in real time - in the midst of a financial upturn - the OI can signal a looming banking crisis, often a few years in advance. This lead time gives policy makers time to take policy actions to contain overheating and for these measures to take effect. These early warnings also afford policy makers time to prepare for potential fallouts, such as upgrading resolution frameworks.

Figure 16. Overheating Index - Out of Sample

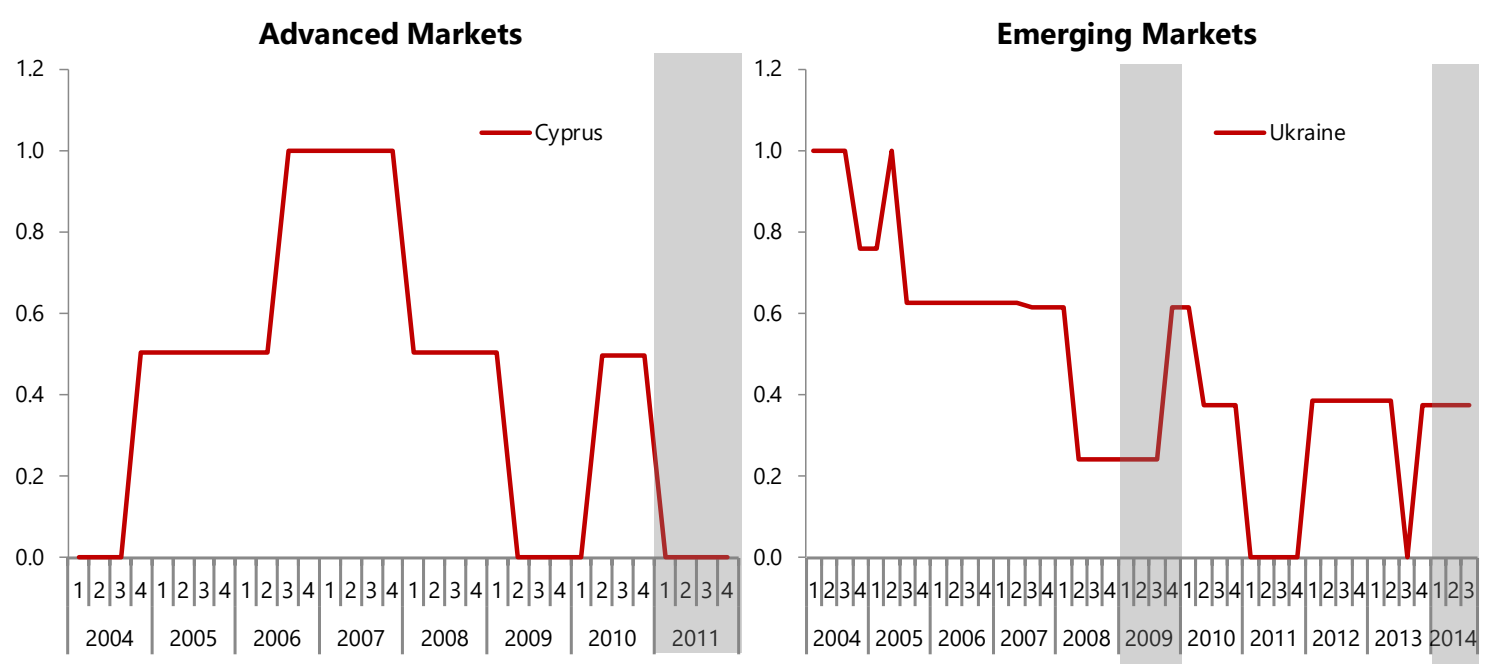

\section{CONCLusions}

Financial crisis extract large costs on the real economy. A thorough understanding of financial cycles is integral to crisis prediction and policy response, all the more so as financial imbalances can grow under seemingly tranquil macroeconomic conditions. Analytical efforts have generated a wide-ranging debate and uncovered numerous insights. Although there is a general consensus that financial cycles behave differently than economic cycles, there is limited agreement on the characteristics of financial cycles.

Using an agnostic approach, we found that on average, the length of financial cycles is on par with, or shorter, than that of business cycles. Moreover, there are variations in cycle duration for different financial variables and across different countries. This finding suggests that a one-size-fits-all metric for cycle extraction used in the calculations for CCyBs across countries may need to be reconsidered. 
As leading indicators of banking crisis, we find that financial variables offer strong predictive power, often on par with and in many instances better than that of real sector variables. On net, equity prices offer the best signal, followed by property prices. By contrast, credit, though widely seen as a strong crisis predictor, does not offer the clearest signals, underscoring the need to look at a wide range of indicators.

Still, predicting the timing of crises is difficult, and most analyses benefit from hindsight. For example, financial cycles extracted with two-sided filters offer stronger predictive power than those with one-sided filters but are not applicable in real time. However, we show that aggregating financial cycle indicators in an overheating index improves prediction in real time; this aggregation underscores the need to look at a wide range of indicators. In short, early warning models presented here can best serve as one of the many inputs in the assessment and identification of financial vulnerabilities. Moreover, given the lagged impact of policy, the lead time afforded by the overheating index can provide room for policy makers to adjust their regulatory and supervisory response and prepare for potential fallouts. Against the uncertainty of a still-evolving research, a prudent approach is to consider a range of indicators and be alert to early signs of a pickup in trends of and widening gaps in financial variables. 


\section{REFERENCES}

Adrian, Tobias and Hyun Shin, 2012. "Procyclical Leverage and Value-at-Risk.," Federal Reserve Bank of New York Staff Report no. 338.

Aguiar, Mark, and Gita Gopinath, 2007. "Emerging Market Business Cycles: The Cycle Is the Trend," Journal of Political Economy: 115, 69-102.

Aikman, David, Andrew G. Haldane, and Benjamin D. Nelson, 2015. "Curbing the Credit Cycle," Economic Journal: 125(585), 1072-1109.

Alessandri, Piergiorgio, Pierluigi Bologna, and Maddalena Galardo, 2021. "Financial crises, macroprudential policy and the reliability of credit-to-GDP gaps," ESRB Working Paper Series 114, European Systemic Risk Board.

Alessi, Lucia and Carsten Detken, 2018. "Identifying excessive credit growth and leverage," Journal of Financial Stability: 5(C), 215-225.

Apoteker, Thierry and Sylvain Barthélémy, 2000. "Genetic Algorithms and Financial Crises in Emerging Markets.” In: AFFI International Conference in Finance Processing.

Bernanke, Ben and Gertler, Mark, 1989. "Agency Costs, Net Worth, and Business Fluctuations," American Economic Review: 79(1), 14-31.

Bernanke, Ben, Mark Gertler, and Simon Gilchrist, 1996. "The Financial Accelerator in a Quantitative Business Cycle Framework" Handbook of Macroeconomics, vol. 1BIS, 2014. "84th Annual Report".

Beutel, Johannes, Sophia List, and Gregor von Schweinitz, 2019. "Does machine learning help us predict banking crises?," Journal of Financial Stability: 45(C).

Borio, Claudio, 2014. "The Financial Cycle and Macroeconomics: What Have We Learnt?" Journal of Banking and Finance: 45(C), 182-198.

Borio, Claudio and Mathias Drehmann, 2009. "Assessing the Risk of Banking Crises Revisited,” BIS Quarterly Review, Bank for International Settlements, March.

Borio, Claudio and Philip Lowe, 2004. "Securing Sustainable Price Stability. Should Credit Come back from the Wilderness?", BIS Working Paper no 157.

Burns, Arthur F., and Wesley C. Mitchell, 1946. Measuring Business Cycles. National Bureau of Economic Research.

Bry, Gerhard and Charlotte Boschan, 1971. Cyclical Analysis of Time Series: Selected Procedures and Computer Programs, New York: NBER.

Canova, Fabio, 1998. "Detrending and Business Cycle Facts," Journal of Monetary Economics: 41(3), 475-512. 
Cerra, Valerie and Sweta C. Saxena, 2002. "Contagion, Monsoons, and Domestic Turmoil in Indonesia's Currency Crisis," Review of International Economics: 10(1), 36-44.

Chamon, Marcos, and Christopher Crowe, 2013. "Chapter 34 - Predictive Indicators of Financial Crises," in The Evidence and Impact of Financial Globalization, edited by Gerard Caprio, Thorsten Beck, Stijn Claessens and Sergio L. Schmukler. Academic Press, San Diego, 2013.

Christiano, Lawrence J. and Terry J. Fitzgerald, 2003. "The Band Pass Filter." International Economic Review: 44(2), 435- 65.

Claessens, Stijn, M. Ayhan Kose, and Marco E. Terrones, 2011a. "Financial Cycles: What? How? When?" IMF Working Paper 11/76

_ 2011b. “How Do Business and Financial Cycles Interact?” IMF Working Paper 11/88

Dell'Ariccia, Giovanni., Deniz Igan, Luc Laeven, Hui Tong, Bas Bakker, and Jerome Vandenbussche, 2012, "Policies for Macrofinancial Stability: How to Deal with Credit Booms," IMF Staff Discussion Note no. 12/06.

Demirgüç-Kunt, Asli and Enrica Detragiache, 2005."Cross-Country Empirical Studies of Systemic Bank Distress: A Survey," National Institute Economic Review: 192(1), 6883.

Drehmann, Mathias, Borio, Claudio, and Kostas Tsatsaronis, 2012. "Characterizing the Financial Cycle: Don’t Lose Sight of the Medium Term!” BIS Working Paper No. 380.

Durbin, James and Siem J. Koopman, 2012. Time Series Analysis by State Space Methods (2nd ed.). Oxford University Press.

Eichengreen, Barry, Andrew Rose, and Charles Wyplosz, 1995. "Exchange Market Mayhem: the Antecedents and Aftermath of Speculative Attacks." Economic Policy: 10 (21), 249-312.

Frankel, Jeffrey A., and Andrew Rose, 1996. "Currency Crashes in Emerging Markets: An Empirical Treatment.” Journal of International Economics: 41(3/4), 351-366.

Frankel, Jeffrey and George Saravelos, 2012. "Can Leading Indicators Assess Country Vulnerability? Evidence from the 2008-09 Global Financial Crisis," Journal of International Economics: 87(2), 216-231.

Frankel, Jeffrey A. and Shang-Jin Wei, 2004. "Managing Macroeconomic Crises." In: Aizenman, J., Pinto, B. (Eds.), Managing Economic Volatility and Crises: A Practitioner's Guide. Cambridge University Press.

Friedman, Benjamin M., "Increasing Indebtedness and Financial Stability in the United States," NBER working paper, No. 2072 (NBER: Cambridge, MA) 
Galati, Gabriele, Irma Hindrayanto, Siem J. Koopman, and Marente Vlekke, 2016. "Measuring Financial Cycles with a Model-based Filter: Empirical Evidence for the United States and the Euro Area," DNB Working Papers 495, Netherlands Central Bank, Research Department.

Geanakoplos, John, 2010. "The Leverage Cycle," pg. 1-65 in the NBER Macroeconomics Annual 2009, vol. 24.

Ghosh, Swati R. and Atish R. Ghosh, 2003. "Structural Vulnerabilities and Currency Crises," IMF Staff Papers: 50(3), 1-7.

Gonzalez, Rodrigo B., Joaquim Lima, and Leonardo Marinho, 2015. "Business and Financial Cycles: an estimation of cycles' length focusing on Macroprudential Policy," Working Papers Series 385, Central Bank of Brazil, Research Department.

Gourinchas, P.O. and M. Obstfeld, 2012, "Stories of the Twentieth Century for the TwentyFirst", American Economic Journal: Macroeconomics, American Economic Association, vol. 4(1), pp. 226-65.

Greenwood, Robin, Samuel G. Hanson, Andrei Shleifer, and Jakob Ahm Sørensen, 2020. "Predictable Financial Crises," NBER Working Papers 27396, National Bureau of Economic Research, Inc.

Hahm, Joon-Ho, Hyun Song Shin, and Kwanho Shin, 2013. "Noncore Bank Liabilities and Financial Vulnerability," Journal of Money, Credit and Banking: 45, 3-36.

Hamilton, James D. 2018. "Why You Should Never Use the Hodrick-Prescott Filter," Review of Economics and Statistics: 100(5), 831-884.

Harding, Don, and Adrian Pagan, 2002a. "Dissecting the Cycle: A Methodological Investigation.” Journal of Monetary Economics: 49 (2), 365-381

_ 2002b. "A Comparison of two Business Cycle Dating Methods," Journal of Economic Dynamics and Control: 27, 1681-690.

Harvey, Andrew C., 1989. Forecasting, Structural Time Series Models and the Kalman Filter. Cambridge University Press.

Harvey, Andrew C. and A. Jaeger, 1993. "Detrending, Stylized Facts and the Business Cycle," Journal of Applied Econometrics: 8(3), 231-247.

Harvey, Andrew C. and Thomas M. Trimbur, 2003. "General Model-Based Filters for Extracting Cycles and Trends in Economic Time Series," The Review of Economics and Statistics: 85(2), 244-255.

Hiebert, Paul, Benjamin Klaus, Tuomas A. Peltonen, Yves S. Schüler, and Peter Welz, 2014. "Capturing the Financial Cycle in Euro Area Countries," Financial Stability Review, European Central Bank, vol. 2. 
Holopainen, Markus and Peter Sarlin, 2017. "Toward robust early-warning models: a horse race, ensembles and model uncertainty," Quantitative Finance: 17(12), 1933-1963.

International Monetary Fund, 2021, "Nonfinancial Sector: Loose Financial Conditions, Rising Leverage, and Risks to Macro-Financial Stability", Chapter 2, "Global Financial Stability Report”, April 2021 (International Monetary Fund: Washington, DC)

Kaminsky, Graciela, Saul Lizondo, and Carmen M. Reinhart, 1998, "Leading Indicators of Currency Crises," IMF Staff Papers, Vol. 45, No. 1.

Kindleberger, Charles. P., 1978. Manias, Panics and Crashes: A History of Financial Crises. Palgrave Macmillan.

Kiyotaki, Nobuhiro and Moore, John, 1997. "Credit Cycles," Journal of Political Economy: 105(2), 211-248.

Koopman, Siem J. and Andre Lucas, 2005. "Business and Default Cycles for Credit Risk," Journal of Applied Econometrics: 20 (2), 311-323.

Laeven, Luc, and Fabián Valencia, 2008, “Systemic Banking Crises: A New Database,” IMF Working Paper 08/224.

— , 2012, “Systemic Banking Crises Database: An Update,” IMF Working Paper 12/163.

— 2018, “Systemic Banking Crises Revisited," IMF Working Paper 18/206.

Martinez Peria, Maria S., 2002. "A Regime-Switching Approach to the Study of Speculative Attacks: A Focus on EMS Crises," Empirical Economics: 27(2), 299-334.

Minsky, Hyman P., 1992. The Financial Instability Hypothesis. Economics Working Paper Archive 74, Levy Economics Institute of Bard College.

Nag, Ashok K. and Amit Mitra, 1999. "Neural Networks and Early Warning Indicators of Currency Crisis.” Reserve Bank of India Occasional Papers: 20 (2), 183-222.

Nelson, Charles R., 1988. "Spurious Trends and Cycle in the State Space Decomposition of a Time Series with a Unit Root.” Journal of Economic Dynamics and Control: 12, 475488.

Preistley, Maurice B., 1999. Spectral Analysis and Time Series, London: Academic Press.

Schularick, Mortiz, and Alan M. Taylor, 2012, "Credit Booms Gone Bust: Monetary Policy, Leverage Cycles, and Financial Crises, 1870-2008," American Economic Review: 102(2), 1029-61.

Schuler, Yves S., 2018. "Detrending and Financial Cycle Facts across G7 Countries: Mind a Spurious Medium Term!," Working Paper Series 2138, European Central Bank.

Schuler, Yves S., Paul Hiebert, and Tuomas Peltonen, 2015. "Characterizing the Financial 
Cycle: a Multivariate and Time-varying Approach," Working Paper Series 1846, European Central Bank. 


\section{Appendix 1. Data Sources}

Indicator

Financial series

1. Stock indicators

Private credit

Total credit to the private non-financial sector

2. Price indicators

Property price

Equity price

3. Leverage or noncore funding indicators

Loan-to-deposit ratio

Real series

Gross Domestic Product

Consumption

Investment

CPI

Inflation deviation from target
Source

International Financial Statistics (IFS)

Bank of International Settlements (BIS)

IMF Research department

Haver

International Financial Statistics (IFS)

World Economic Outlook

World Economic Outlook

World Economic Outlook

International Financial Statistics (IFS)

IMF Research department

Laeven and Valencia (2018)

Banking Crises

0-1 indicator of systemic banking crisis

\section{Haver}

Haver

Cyclically-adjusted primary balance

World Economic Outlook

Capital controls

Chinn-Ito Index

REER

World Economic Outlook 
Appendix 2. Cycle Properties by Country

Table 1A. Credit Cycles (AM)

\begin{tabular}{|c|c|c|c|c|c|}
\hline Number of cycles & 144 & & total & peak & trough \\
\hline Average cycle length (years): & & & 7.1 & 5.6 & 1.5 \\
\hline Median cycle length (years): & & & 6.6 & 5.4 & 1.2 \\
\hline St. dev. & & & 2.7 & 2.6 & 0.8 \\
\hline \multicolumn{6}{|c|}{ Peaks } \\
\hline Country & Number & $\begin{array}{r}\text { Time (\% share } \\
\text { of total time) }\end{array}$ & $\begin{array}{r}\text { Duration } \\
\text { (number of } \\
\text { quarters) }\end{array}$ & $\begin{array}{r}\text { Amplitude } \\
\text { (\% change } \\
\text { between peak }\end{array}$ & $\begin{array}{r}\text { Slope } \\
\text { (amplitude/dura } \\
\text { tion) }\end{array}$ \\
\hline 1 Australia & 5 & 51.9 & 24.0 & 57.9 & 2.4 \\
\hline 2 Austria & 5 & 42.4 & 24.5 & 27.2 & 1.1 \\
\hline 3 Belgium & 6 & 54.0 & 19.0 & 27.3 & 1.4 \\
\hline 4 Canada & 5 & 79.1 & 36.4 & 71.7 & 2.0 \\
\hline 5 Cyprus & 6 & 89.0 & 40.4 & 99.6 & 2.5 \\
\hline 6 Czech Republic & 2 & 2.3 & 2.0 & 12.5 & 6.2 \\
\hline 7 Denmark & 8 & 68.4 & 16.3 & 25.5 & 1.6 \\
\hline 8 Estonia & 4 & 61.5 & 14.0 & 100.1 & 7.1 \\
\hline 9 Finland & 4 & 69.3 & 37.7 & 70.6 & 1.9 \\
\hline 10 France & 6 & 72.2 & 26.0 & 24.2 & 0.9 \\
\hline \multicolumn{6}{|l|}{11 Germany } \\
\hline 12 Greece & 11 & 60.3 & 12.0 & 38.7 & 3.2 \\
\hline 13 Hong Kong SAR & 8 & 64.0 & 12.4 & 29.3 & 2.4 \\
\hline 14 Iceland & 6 & 61.4 & 13.0 & 56.8 & 4.4 \\
\hline \multicolumn{6}{|l|}{15 Ireland } \\
\hline 16 Israel & 7 & 85.1 & 31.5 & 91.3 & 2.9 \\
\hline 17 Italy & 4 & 66.9 & 35.7 & 48.8 & 1.4 \\
\hline 18 Japan & 8 & 46.8 & 15.4 & 19.8 & 1.3 \\
\hline 19 Korea & 5 & 77.7 & 34.8 & 95.5 & 2.7 \\
\hline 20 Luxembourg & 2 & 57.1 & 18.0 & 54.6 & 3.0 \\
\hline \multicolumn{6}{|l|}{21 Malta } \\
\hline 22 Netherlands & 4 & 51.9 & 9.0 & 10.9 & 1.2 \\
\hline 23 New Zealand & 11 & 72.5 & 15.8 & 47.5 & 3.0 \\
\hline 24 Norway & 8 & 81.3 & 26.7 & 47.2 & 1.8 \\
\hline 25 Portugal & 12 & 68.4 & 14.4 & 33.8 & 2.4 \\
\hline 26 Singapore & 5 & 56.9 & 27.8 & 71.9 & 2.6 \\
\hline 27 Slovak Republic & 6 & 50.6 & 7.3 & 31.4 & 4.3 \\
\hline 28 Slovenia & 3 & 71.4 & 32.5 & 108.8 & 3.3 \\
\hline 29 Spain & 4 & 57.0 & 34.0 & 66.6 & 2.0 \\
\hline 30 Sweden & 7 & 43.9 & 15.7 & 21.3 & 1.4 \\
\hline 31 Switzerland & 8 & 44.6 & 14.7 & 20.9 & 1.4 \\
\hline \multicolumn{6}{|l|}{32 Taiwan Province of China } \\
\hline 33 United Kingdom & 3 & 63.6 & 34.0 & 62.1 & 1.8 \\
\hline 34 United States & 5 & 52.8 & 30.5 & 38.2 & 1.3 \\
\hline mean & 5.9 & 60.8 & 22.5 & 50.4 & 2.5 \\
\hline median & 5.5 & 61.5 & 21.5 & 47.4 & 2.2 \\
\hline st. dev. & 2.5 & 16.6 & 10.5 & 28.3 & 1.5 \\
\hline sum & 178 & & & & \\
\hline
\end{tabular}


Table 1A. Credit Cycles (AM)

Troughs

\begin{tabular}{|c|c|c|c|c|c|}
\hline Country & Number & $\begin{array}{r}\text { Time (\% share } \\
\text { of total time) }\end{array}$ & $\begin{array}{r}\text { Duration } \\
\text { (number of } \\
\text { quarters) }\end{array}$ & $\begin{array}{r}\text { Amplitude } \\
\text { (\% change } \\
\text { between peak } \\
\text { and trough) } \\
\end{array}$ & $\begin{array}{r}\text { Slope } \\
\text { (amplitude/dura } \\
\text { tion) } \\
\end{array}$ \\
\hline 1 Australia & 6 & 7 & 3 & -6 & -2 \\
\hline 2 Austria & 4 & 5 & 3 & -1 & 0 \\
\hline 3 Belgium & 6 & 34 & 10 & -10 & -1 \\
\hline 4 Canada & 6 & 9 & 4 & -5 & -1 \\
\hline 5 Cyprus & 6 & 8 & 3 & -3 & -1 \\
\hline 6 Czech Republic & 2 & 34 & 15 & -39 & -3 \\
\hline 7 Denmark & 9 & 29 & 7 & -4 & -1 \\
\hline 8 Estonia & 5 & 27 & 6 & -11 & -2 \\
\hline 9 Finland & 3 & 26 & 14 & -12 & -1 \\
\hline 10 France & 5 & 17 & 6 & -3 & 0 \\
\hline \multicolumn{6}{|l|}{11 Germany } \\
\hline 12 Greece & 11 & 28 & 6 & -9 & -1 \\
\hline 13 Hong Kong SAR & 8 & 21 & 4 & -6 & -2 \\
\hline 14 Iceland & 7 & 32 & 7 & -26 & -4 \\
\hline \multicolumn{6}{|l|}{15 Ireland } \\
\hline 16 Israel & 7 & 9 & 3 & -7 & -3 \\
\hline 17 Italy & 3 & 22 & 12 & -8 & -1 \\
\hline 18 Japan & 7 & 23 & 8 & -13 & -2 \\
\hline 19 Korea & 5 & 7 & 2 & -2 & -1 \\
\hline 20 Luxembourg & 3 & 14 & 5 & -17 & -4 \\
\hline \multicolumn{6}{|l|}{21 Malta } \\
\hline 22 Netherlands & 3 & 27 & 5 & -6 & -1 \\
\hline 23 New Zealand & 10 & 24 & 5 & -12 & -2 \\
\hline 24 Norway & 8 & 14 & 4 & -5 & -1 \\
\hline 25 Portugal & 11 & 19 & 4 & -6 & -1 \\
\hline 26 Singapore & 5 & 10 & 4 & -4 & -1 \\
\hline 27 Slovak Republic & 7 & 28 & 4 & -16 & -4 \\
\hline 28 Slovenia & 2 & 4 & 2 & -3 & -1 \\
\hline 29 Spain & 3 & 15 & 9 & -7 & -1 \\
\hline 30 Sweden & 7 & 19 & 6 & -7 & -1 \\
\hline 31 Switzerland & 8 & 18 & 5 & -5 & -1 \\
\hline \multicolumn{6}{|c|}{32 Taiwan Province of China } \\
\hline 33 United Kingdom & 2 & 7 & 4 & -5 & -1 \\
\hline 34 United States & 5 & 19 & 9 & -12 & -1 \\
\hline mean & 5.8 & 18.6 & 5.9 & -9.0 & -1.5 \\
\hline median & 6.0 & 18.9 & 4.9 & -6.5 & -1.3 \\
\hline st. dev. & 2.6 & 9.1 & 3.2 & 7.6 & 1.0 \\
\hline sum & 174 & & & & \\
\hline
\end{tabular}


Table 1B. Credit Cycles (EM)

\begin{tabular}{|c|c|c|c|c|c|}
\hline \multicolumn{2}{|c|}{ Number of cycles $\quad 107$} & & total & peak & trough \\
\hline \multicolumn{2}{|c|}{ Average cycle length (years): } & & 6.0 & 4.5 & 1.5 \\
\hline \multicolumn{2}{|c|}{ Median cycle length (years): } & & 5.2 & 3.8 & 1.5 \\
\hline \multicolumn{2}{|c|}{ St. dev. } & & 2.4 & 2.3 & 0.5 \\
\hline & Peaks & & & \\
\hline Country & Number & $\begin{array}{r}\text { Time (\% share } \\
\text { of total time) }\end{array}$ & $\begin{array}{r}\text { Duration } \\
\text { (number of } \\
\text { quarters) } \\
\end{array}$ & $\begin{array}{r}\text { Amplitude } \\
\text { (\% change } \\
\text { between peak }\end{array}$ & $\begin{array}{r}\text { Slope } \\
\text { (amplitude/dura } \\
\text { tion) }\end{array}$ \\
\hline 1 Argentina & 5 & 50.4 & 11.6 & 49.9 & 4.3 \\
\hline 2 Brazil & 5 & 43.9 & 12.2 & 49.0 & 4.0 \\
\hline 3 Bulgaria & 3 & 60.9 & 18.7 & 101.4 & 5.4 \\
\hline \multicolumn{6}{|l|}{4 China } \\
\hline 5 Colombia & 10 & 59.7 & 13.8 & 42.7 & 3.1 \\
\hline 6 Croatia & 3 & 53.1 & 21.5 & 62.8 & 2.9 \\
\hline 7 Hungary & 6 & 43.8 & 11.2 & 39.4 & 3.5 \\
\hline 8 India & 8 & 56.7 & 18.7 & 48.0 & 2.6 \\
\hline 9 Indonesia & 3 & 19.4 & 13.5 & 53.6 & 4.0 \\
\hline 10 Lithuania & 3 & 43.0 & 18.5 & 136.0 & 7.3 \\
\hline 11 Malaysia & 4 & 66.2 & 38.3 & 156.2 & 4.1 \\
\hline 12 Mexico & 7 & 58.7 & 19.3 & 75.8 & 3.9 \\
\hline 13 Philippines & 5 & 46.8 & 13.0 & 41.8 & 3.2 \\
\hline 14 Poland & 9 & 52.2 & 8.9 & 30.9 & 3.5 \\
\hline 15 Russia & 4 & 75.9 & 21.0 & 106.2 & 5.1 \\
\hline 16 Serbia & 3 & 63.2 & 14.3 & 76.9 & 5.4 \\
\hline 17 SouthAfrica & 7 & 62.6 & 18.2 & 36.2 & 2.0 \\
\hline 18 Thailand & 4 & 48.7 & 32.3 & 99.8 & 3.1 \\
\hline 19 Turkey & 9 & 56.8 & 13.0 & 58.8 & 4.5 \\
\hline 20 Ukraine & 4 & 71.6 & 15.8 & 172.9 & 11.0 \\
\hline 21 Uruguay & 15 & 52.8 & 8.1 & 39.9 & 4.9 \\
\hline 22 Latvia & 2 & 57.1 & 48.0 & 361.0 & 7.5 \\
\hline 23 Kazakhstan & 3 & 65.5 & 18.3 & 142.3 & 7.8 \\
\hline 24 Romania & 3 & 58.3 & 14.0 & 103.9 & 7.4 \\
\hline 25 Vietnam & 2 & 12.7 & 10.0 & 51.5 & 5.1 \\
\hline mean & 5.3 & 53.3 & 18.0 & 89.0 & 4.8 \\
\hline median & 4.0 & 56.8 & 15.0 & 60.8 & 4.2 \\
\hline st. dev. & 3.1 & 14.3 & 9.4 & 71.1 & 2.1 \\
\hline sum & 127 & & & & \\
\hline
\end{tabular}


Table 1B. Credit Cycles (EM)

Troughs

\begin{tabular}{|c|c|c|c|c|c|}
\hline Country & Number & $\begin{array}{r}\text { Time (\% share } \\
\text { of total time) }\end{array}$ & $\begin{array}{r}\text { Duration } \\
\text { (number of } \\
\text { quarters) }\end{array}$ & $\begin{array}{r}\text { Amplitude } \\
\text { (\% change } \\
\text { between peak } \\
\text { and trough) } \\
\end{array}$ & $\begin{array}{r}\text { Slope } \\
\text { (amplitude/dura } \\
\text { tion) }\end{array}$ \\
\hline 1 Argentina & 6 & 32.2 & 7.4 & -46.3 & -6.3 \\
\hline 2 Brazil & 6 & 20.9 & 5.8 & -34.5 & -6.0 \\
\hline 3 Bulgaria & 4 & 16.3 & 5.0 & -68.2 & -13.6 \\
\hline \multicolumn{6}{|l|}{4 China } \\
\hline 5 Colombia & 11 & 29.0 & 6.7 & -12.7 & -1.9 \\
\hline 6 Croatia & 2 & 8.6 & 3.5 & -7.6 & -2.2 \\
\hline 7 Hungary & 6 & 37.5 & 8.0 & -30.4 & -3.8 \\
\hline 8 India & 8 & 14.3 & 4.1 & -6.1 & -1.5 \\
\hline 9 Indonesia & 3 & 8.6 & 4.0 & -50.1 & -12.5 \\
\hline 10 Lithuania & 3 & 43.0 & 12.3 & -26.5 & -2.1 \\
\hline 11 Malaysia & 5 & 6.1 & 3.5 & -5.0 & -1.4 \\
\hline 12 Mexico & 8 & 22.2 & 7.3 & -42.6 & -5.8 \\
\hline 13 Philippines & 5 & 21.6 & 4.8 & -9.9 & -2.1 \\
\hline 14 Poland & 9 & 39.0 & 5.9 & -26.9 & -4.6 \\
\hline 15 Russia & 3 & 16.9 & 4.7 & -17.2 & -3.7 \\
\hline 16 Serbia & 4 & 20.6 & 4.7 & -39.9 & -8.6 \\
\hline 17 SouthAfrica & 7 & 23.6 & 5.9 & -9.2 & -1.6 \\
\hline 18 Thailand & 4 & 12.1 & 6.0 & -16.8 & -2.8 \\
\hline 19 Turkey & 9 & 27.3 & 5.6 & -27.3 & -4.9 \\
\hline 20 Ukraine & 4 & 20.5 & 6.0 & -49.6 & -8.3 \\
\hline 21 Uruguay & 15 & 44.6 & 7.4 & -34.8 & -4.7 \\
\hline 22 Latvia & 1 & 8.3 & 7.0 & -90.7 & -13.0 \\
\hline 23 Kazakhstan & 3 & 14.3 & 6.0 & -14.4 & -2.4 \\
\hline 24 Romania & 3 & 20.8 & 7.5 & -34.5 & -4.6 \\
\hline 25 Vietnam & 2 & 5.1 & 2.0 & -8.1 & -4.0 \\
\hline mean & 5.5 & 21.4 & 5.9 & -29.6 & -5.1 \\
\hline median & 4.5 & 20.7 & 5.9 & -27.1 & -4.3 \\
\hline st. dev. & 3.3 & 11.5 & 2.0 & 21.3 & 3.7 \\
\hline sum & 131 & & & & \\
\hline
\end{tabular}


Table 2A. BIS-Definition Credit Cycles (AM)

\begin{tabular}{|c|c|c|c|c|c|}
\hline Number of cycles & 117 & & total & peak & trough \\
\hline Average cycle length (years): & & & 7.3 & 6.0 & 1.4 \\
\hline Median cycle length (years): & & & 6.4 & 5.2 & 1.2 \\
\hline St. dev. & & & 3.4 & 3.3 & 0.6 \\
\hline \multicolumn{6}{|c|}{ Peaks } \\
\hline Country & Number & $\begin{array}{r}\text { Time (\% share } \\
\text { of total time) }\end{array}$ & $\begin{array}{r}\text { Duration } \\
\text { (number of } \\
\text { quarters) } \\
\end{array}$ & $\begin{array}{r}\text { Amplitude } \\
\text { (\% change } \\
\text { between peak }\end{array}$ & $\begin{array}{r}\text { Slope } \\
\text { (amplitude/dura } \\
\text { tion }\end{array}$ \\
\hline 1 Australia & 6 & 85.7 & 32.8 & 55.2 & 1.7 \\
\hline 2 Austria & 5 & 46.1 & 26.5 & 30.9 & 1.2 \\
\hline 3 Belgium & 4 & 68.6 & 40.0 & 66.7 & 1.7 \\
\hline 4 Canada & 4 & 58.3 & 33.5 & 55.4 & 1.7 \\
\hline \multicolumn{6}{|l|}{5 Cyprus } \\
\hline 6 Czech Republic & 5 & 47.7 & 10.3 & 19.1 & 1.9 \\
\hline 7 Denmark & 9 & 72.6 & 15.3 & 23.0 & 1.5 \\
\hline \multicolumn{6}{|l|}{8 Estonia } \\
\hline 9 Finland & 7 & 78.9 & 19.7 & 30.8 & 1.6 \\
\hline 10 France & 7 & 69.8 & 20.8 & 21.4 & 1.0 \\
\hline 11 Germany & 4 & 10.6 & 3.3 & 1.5 & 0.5 \\
\hline 12 Greece & 7 & 50.9 & 18.5 & 41.6 & 2.2 \\
\hline 13 Hong Kong SAR & 6 & 66.7 & 18.0 & 40.5 & 2.3 \\
\hline \multicolumn{6}{|l|}{14 Iceland } \\
\hline 15 Ireland & 3 & 47.1 & 16.5 & 52.1 & 3.2 \\
\hline \multicolumn{6}{|l|}{16 Israel } \\
\hline 17 Italy & 11 & 46.1 & 10.6 & 15.7 & 1.5 \\
\hline 18 Japan & 6 & 48.7 & 19.4 & 23.6 & 1.2 \\
\hline 19 Korea & 3 & 59.0 & 52.5 & 175.2 & 3.3 \\
\hline 20 Luxembourg & 4 & 40.0 & 6.7 & 24.7 & 3.7 \\
\hline \multicolumn{6}{|l|}{21 Malta } \\
\hline 22 Netherlands & 4 & 51.9 & 37.0 & 48.2 & 1.3 \\
\hline \multicolumn{6}{|l|}{23 New Zealand } \\
\hline 24 Norway & 5 & 79.1 & 45.5 & 69.9 & 1.5 \\
\hline 25 Portugal & 12 & 65.2 & 13.6 & 32.4 & 2.4 \\
\hline 26 Singapore & 7 & 62.1 & 21.0 & 50.7 & 2.4 \\
\hline \multicolumn{6}{|l|}{27 Slovak Republic } \\
\hline \multicolumn{6}{|l|}{28 Slovenia } \\
\hline 29 Spain & 5 & 58.4 & 26.0 & 47.1 & 1.8 \\
\hline 30 Sweden & 6 & 31.8 & 13.6 & 19.0 & 1.4 \\
\hline 31 Switzerland & 5 & 37.8 & 21.8 & 25.3 & 1.2 \\
\hline \multicolumn{6}{|l|}{32 Taiwan Province of China } \\
\hline 33 United Kingdom & 4 & 62.3 & 22.0 & 33.2 & 1.5 \\
\hline 34 United States & 3 & 44.3 & 51.0 & 63.6 & 1.2 \\
\hline mean & 5.7 & 55.6 & 23.8 & 42.7 & 1.8 \\
\hline median & 5.0 & 58.3 & 20.8 & 33.2 & 1.6 \\
\hline st. dev. & 2.3 & 16.7 & 13.2 & 32.7 & 0.8 \\
\hline sum & 142 & & & & \\
\hline
\end{tabular}


Table 2A. BIS-Definition Credit Cycles (AM)

Troughs

\begin{tabular}{|c|c|c|c|c|c|}
\hline Country & Number & $\begin{array}{r}\text { Time (\% share } \\
\text { of total time) }\end{array}$ & $\begin{array}{r}\text { Duration } \\
\text { (number of } \\
\text { quarters) }\end{array}$ & $\begin{array}{r}\text { Amplitude } \\
\text { (\% change } \\
\text { between peak } \\
\text { and trough) } \\
\end{array}$ & $\begin{array}{r}\text { Slope } \\
\text { (amplitude/dura } \\
\text { tion) }\end{array}$ \\
\hline 1 Australia & 7 & 8 & 3 & -2 & -1 \\
\hline 2 Austria & 4 & 4 & 3 & -1 & 0 \\
\hline 3 Belgium & 4 & 22 & 10 & -7 & -1 \\
\hline 4 Canada & 5 & 7 & 4 & -4 & -1 \\
\hline \multicolumn{6}{|l|}{5 Cyprus } \\
\hline 6 Czech Republic & 5 & 33 & 6 & -8 & -1 \\
\hline 7 Denmark & 9 & 21 & 5 & -3 & -1 \\
\hline \multicolumn{6}{|l|}{8 Estonia } \\
\hline 9 Finland & 8 & 18 & 4 & -5 & -1 \\
\hline 10 France & 7 & 12 & 3 & -1 & 0 \\
\hline 11 Germany & 4 & 34 & 8 & -4 & -1 \\
\hline 12 Greece & 6 & 17 & 6 & -10 & -2 \\
\hline 13 Hong Kong SAR & 6 & 19 & 4 & -6 & -1 \\
\hline \multicolumn{6}{|l|}{14 Iceland } \\
\hline 15 Ireland & 3 & 16 & 4 & -6 & -2 \\
\hline \multicolumn{6}{|l|}{16 Israel } \\
\hline 17 Italy & 10 & 18 & 4 & -3 & -1 \\
\hline 18 Japan & 5 & 31 & 12 & -8 & -1 \\
\hline 19 Korea & 3 & 8 & 5 & -6 & -1 \\
\hline 20 Luxembourg & 4 & 32 & 4 & -5 & -1 \\
\hline \multicolumn{6}{|l|}{21 Malta } \\
\hline 22 Netherlands & 3 & 6 & 4 & -1 & 0 \\
\hline \multicolumn{6}{|l|}{23 New Zealand } \\
\hline 24 Norway & 5 & 12 & 5 & -4 & -1 \\
\hline 25 Portugal & 11 & 22 & 5 & -5 & -1 \\
\hline 26 Singapore & 7 & 11 & 3 & -2 & -1 \\
\hline \multicolumn{6}{|l|}{27 Slovak Republic } \\
\hline \multicolumn{6}{|l|}{28 Slovenia } \\
\hline 29 Spain & 4 & 17 & 8 & -5 & -1 \\
\hline 30 Sweden & 6 & 18 & 6 & -6 & -1 \\
\hline 31 Switzerland & 5 & 13 & 6 & -4 & -1 \\
\hline \multicolumn{6}{|c|}{32 Taiwan Province of China } \\
\hline 33 United Kingdom & 3 & 18 & 6 & -6 & -1 \\
\hline 34 United States & 3 & 12 & 9 & -6 & -1 \\
\hline mean & 5.5 & 17.1 & 5.5 & -4.8 & -0.9 \\
\hline median & 5.0 & 17.4 & 4.9 & -4.9 & -0.8 \\
\hline st. dev. & 2.2 & 8.4 & 2.3 & 2.3 & 0.4 \\
\hline sum & 137 & & & & \\
\hline
\end{tabular}


Table 2B. BIS-Definition Credit Cycles (EM)

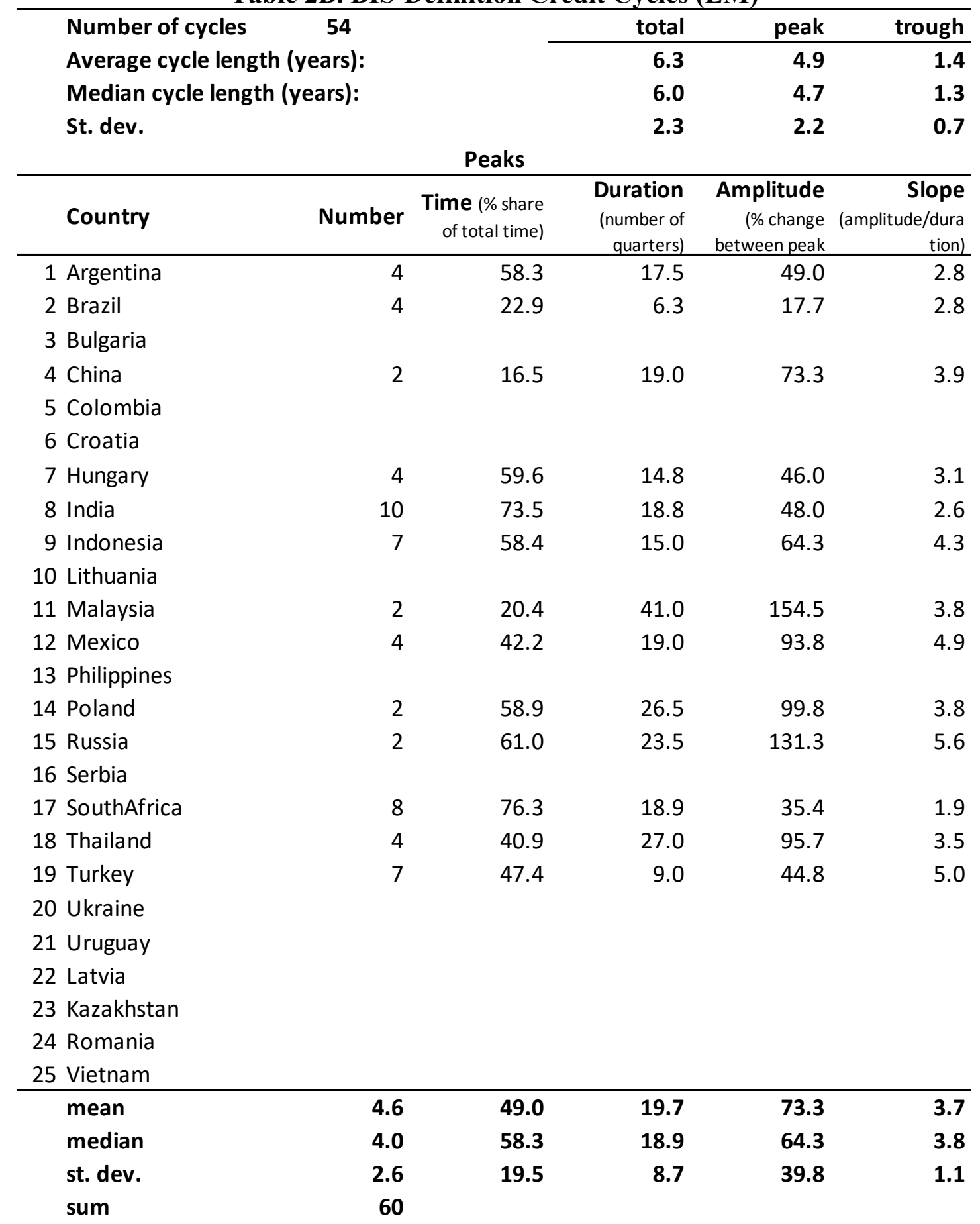


Table 2B. BIS-Definition Credit Cycles (EM)

Troughs

\begin{tabular}{|c|c|c|c|c|c|}
\hline Country & Number & $\begin{array}{r}\text { Time (\% share } \\
\text { of total time) }\end{array}$ & $\begin{array}{r}\text { Duration } \\
\text { (number of } \\
\text { quarters) }\end{array}$ & $\begin{array}{r}\text { Amplitude } \\
\text { (\% change } \\
\text { between peak } \\
\text { and trough) } \\
\end{array}$ & $\begin{array}{r}\text { Slope } \\
\text { (amplitude/dura } \\
\text { tion) }\end{array}$ \\
\hline 1 Argentina & 5 & 24.2 & 7.3 & -42.5 & -5.9 \\
\hline 2 Brazil & 4 & 27.7 & 5.8 & -10.5 & -1.8 \\
\hline \multicolumn{6}{|l|}{3 Bulgaria } \\
\hline 4 China & 2 & 6.1 & 3.5 & -5.7 & -1.6 \\
\hline \multicolumn{6}{|l|}{5 Colombia } \\
\hline \multicolumn{6}{|l|}{6 Croatia } \\
\hline 7 Hungary & 5 & 21.2 & 5.3 & -12.7 & -2.4 \\
\hline 8 India & 10 & 16.5 & 3.8 & -4.6 & -1.2 \\
\hline 9 Indonesia & 7 & 16.2 & 3.6 & -26.4 & -7.4 \\
\hline \multicolumn{6}{|l|}{10 Lithuania } \\
\hline 11 Malaysia & 2 & 6.0 & 6.0 & -7.4 & -1.2 \\
\hline 12 Mexico & 4 & 40.0 & 13.5 & -50.6 & -3.8 \\
\hline \multicolumn{6}{|l|}{13 Philippines } \\
\hline 14 Poland & 3 & 7.8 & 3.5 & -6.6 & -1.9 \\
\hline 15 Russia & 3 & 9.1 & 3.5 & -24.2 & -6.9 \\
\hline \multicolumn{6}{|l|}{16 Serbia } \\
\hline 17 SouthAfrica & 8 & 20.2 & 5.7 & -8.7 & -1.5 \\
\hline 18 Thailand & 4 & 12.1 & 6.0 & -16.5 & -2.8 \\
\hline 19 Turkey & 7 & 28.9 & 4.7 & -17.7 & -3.7 \\
\hline \multicolumn{6}{|l|}{20 Ukraine } \\
\hline \multicolumn{6}{|l|}{21 Uruguay } \\
\hline \multicolumn{6}{|l|}{22 Latvia } \\
\hline \multicolumn{6}{|l|}{23 Kazakhstan } \\
\hline \multicolumn{6}{|l|}{24 Romania } \\
\hline \multicolumn{6}{|l|}{25 Vietnam } \\
\hline mean & 4.9 & 18.2 & 5.5 & -18.0 & -3.2 \\
\hline median & 4.0 & 16.5 & 5.3 & -12.7 & -2.4 \\
\hline st. dev. & 2.4 & 10.3 & 2.7 & 14.5 & 2.2 \\
\hline sum & 64 & & & & \\
\hline
\end{tabular}


Table 3A. LTDR Cycles (AM)

\begin{tabular}{|c|c|c|c|c|c|}
\hline Number of cycles & 291 & & total & peak & trough \\
\hline \multicolumn{2}{|c|}{ Average cycle length (years): } & & 4.2 & 2.3 & 1.9 \\
\hline \multicolumn{2}{|c|}{ Median cycle length (years): } & & 3.9 & 2.1 & 1.7 \\
\hline \multicolumn{2}{|c|}{ St. dev. } & & 1.3 & 0.9 & 0.9 \\
\hline \multicolumn{6}{|c|}{ Peaks } \\
\hline Country & Number & $\begin{array}{r}\text { Time (\% share } \\
\text { of total time) }\end{array}$ & $\begin{array}{r}\text { Duration } \\
\text { (number of } \\
\text { quarters) } \\
\end{array}$ & $\begin{array}{r}\text { Amplitude } \\
\text { (\% change } \\
\text { between peak }\end{array}$ & $\begin{array}{r}\text { Slope } \\
\text { (amplitude/dura } \\
\text { tion) } \\
\end{array}$ \\
\hline 1 Australia & 16 & 65.4 & 9.4 & 14.2 & 1.5 \\
\hline 2 Austria & 15 & 55.5 & 8.4 & 6.9 & 0.8 \\
\hline 3 Belgium & 8 & 38.1 & 8.4 & 9.6 & 1.2 \\
\hline 4 Canada & 15 & 58.3 & 8.9 & 13.0 & 1.5 \\
\hline 5 Cyprus & 19 & 58.1 & 6.9 & 9.2 & 1.3 \\
\hline 6 Czech Republic & 4 & 43.0 & 9.3 & 17.7 & 1.9 \\
\hline 7 Denmark & 14 & 51.7 & 8.5 & 11.7 & 1.4 \\
\hline 8 Estonia & 3 & 51.1 & 23.5 & 74.2 & 3.2 \\
\hline 9 Finland & 8 & 59.5 & 12.1 & 11.4 & 0.9 \\
\hline 10 France & 11 & 52.2 & 8.5 & 7.7 & 0.9 \\
\hline 11 Germany & 11 & 42.0 & 8.8 & 7.7 & 0.9 \\
\hline 12 Greece & 12 & 50.2 & 9.2 & 24.2 & 2.6 \\
\hline 13 Hong Kong SAR & 4 & 22.3 & 5.3 & 15.9 & 3.0 \\
\hline 14 Iceland & 17 & 48.9 & 6.6 & 18.1 & 2.7 \\
\hline 15 Ireland & 9 & 37.4 & 8.1 & 19.7 & 2.4 \\
\hline 16 Israel & 5 & 21.8 & 3.4 & 7.2 & 2.1 \\
\hline 17 Italy & 8 & 58.1 & 11.6 & 17.3 & 1.5 \\
\hline 18 Japan & 7 & 25.1 & 8.3 & 6.0 & 0.7 \\
\hline 19 Korea & 15 & 53.0 & 8.3 & 16.2 & 1.9 \\
\hline 20 Luxembourg & 7 & 44.4 & 4.7 & 18.0 & 3.9 \\
\hline 21 Malta & 2 & 51.3 & 10.0 & 11.8 & 1.2 \\
\hline 22 Netherlands & 5 & 46.2 & 6.0 & 7.0 & 1.2 \\
\hline 23 New Zealand & 18 & 63.8 & 8.2 & 17.0 & 2.1 \\
\hline 24 Norway & 5 & 54.7 & 11.8 & 15.8 & 1.3 \\
\hline 25 Portugal & 17 & 55.0 & 7.9 & 14.0 & 1.8 \\
\hline 26 Singapore & 9 & 44.1 & 10.8 & 19.6 & 1.8 \\
\hline 27 Slovak Republic & 3 & 47.1 & 13.7 & 43.7 & 3.2 \\
\hline 28 Slovenia & 3 & 50.0 & 15.3 & 36.7 & 2.4 \\
\hline 29 Spain & 7 & 58.1 & 14.9 & 21.0 & 1.4 \\
\hline 30 Sweden & 10 & 45.5 & 8.1 & 12.5 & 1.5 \\
\hline 31 Switzerland & 14 & 47.8 & 6.9 & 7.5 & 1.1 \\
\hline \multicolumn{6}{|c|}{32 Taiwan Province of China } \\
\hline 33 United Kingdom & 11 & 43.0 & 8.9 & 20.4 & 2.3 \\
\hline 34 United States & 12 & 48.9 & 9.4 & 8.6 & 0.9 \\
\hline mean & 9.8 & 48.2 & 9.4 & 17.0 & 1.8 \\
\hline median & 9.0 & 50.0 & 8.5 & 14.2 & 1.5 \\
\hline st. dev. & 5.0 & 10.5 & 3.6 & 13.1 & 0.8 \\
\hline sum & 324 & & & & \\
\hline
\end{tabular}


Table 3A. LTDR Cycles (AM)

Troughs

\begin{tabular}{|c|c|c|c|c|c|}
\hline Country & Number & $\begin{array}{r}\text { Time (\% share } \\
\text { of total time) }\end{array}$ & $\begin{array}{r}\text { Duration } \\
\text { (number of } \\
\text { quarters) }\end{array}$ & $\begin{array}{r}\text { Amplitude } \\
\text { (\% change } \\
\text { between peak } \\
\text { and trough) } \\
\end{array}$ & $\begin{array}{r}\text { Slope } \\
\text { (amplitude/dura } \\
\text { tion) }\end{array}$ \\
\hline 1 Australia & 17 & 32 & 5 & -7 & -1 \\
\hline 2 Austria & 16 & 41 & 6 & -5 & -1 \\
\hline 3 Belgium & 8 & 52 & 13 & -25 & -2 \\
\hline 4 Canada & 15 & 37 & 6 & -6 & -1 \\
\hline 5 Cyprus & 19 & 38 & 5 & -7 & -1 \\
\hline 6 Czech Republic & 4 & 28 & 8 & -27 & -3 \\
\hline 7 Denmark & 14 & 39 & 7 & -11 & -2 \\
\hline 8 Estonia & 2 & 11 & 5 & -15 & -3 \\
\hline 9 Finland & 9 & 34 & 7 & -7 & -1 \\
\hline 10 France & 11 & 40 & 7 & -14 & -2 \\
\hline 11 Germany & 11 & 45 & 10 & -11 & -1 \\
\hline 12 Greece & 12 & 37 & 7 & -20 & -3 \\
\hline 13 Hong Kong SAR & 4 & 17 & 5 & -16 & -3 \\
\hline 14 Iceland & 18 & 47 & 6 & -20 & -3 \\
\hline 15 Ireland & 8 & 46 & 10 & -15 & -1 \\
\hline 16 Israel & 5 & 26 & 5 & -7 & -1 \\
\hline 17 Italy & 8 & 31 & 7 & -10 & -1 \\
\hline 18 Japan & 8 & 70 & 23 & -20 & -1 \\
\hline 19 Korea & 14 & 40 & 6 & -13 & -2 \\
\hline 20 Luxembourg & 6 & 41 & 4 & -14 & -3 \\
\hline 21 Malta & 2 & 13 & 5 & -10 & -2 \\
\hline 22 Netherlands & 4 & 42 & 6 & -12 & -2 \\
\hline 23 New Zealand & 17 & 32 & 4 & -12 & -3 \\
\hline 24 Norway & 4 & 13 & 3 & -2 & -1 \\
\hline 25 Portugal & 16 & 39 & 6 & -9 & -2 \\
\hline 26 Singapore & 9 & 44 & 10 & -19 & -2 \\
\hline 27 Slovak Republic & 4 & 37 & 11 & -27 & -2 \\
\hline 28 Slovenia & 3 & 15 & 7 & -16 & -2 \\
\hline 29 Spain & 7 & 28 & 9 & -11 & -1 \\
\hline 30 Sweden & 10 & 35 & 7 & -10 & -1 \\
\hline 31 Switzerland & 15 & 50 & 7 & -8 & -1 \\
\hline \multicolumn{6}{|c|}{32 Taiwan Province of China } \\
\hline 33 United Kingdom & 11 & 51 & 10 & -15 & -2 \\
\hline 34 United States & 13 & 47 & 9 & -9 & -1 \\
\hline mean & 9.8 & 36.3 & 7.4 & -13.0 & -1.8 \\
\hline median & 9.0 & 37.9 & 6.9 & -11.6 & -1.6 \\
\hline st. dev. & 5.1 & 12.8 & 3.6 & 6.2 & 0.8 \\
\hline sum & 324 & & & & \\
\hline
\end{tabular}


Table 3B. LTDR Cycles (EM)

\begin{tabular}{|c|c|c|c|c|c|}
\hline Number of cycles & 92 & & total & peak & trough \\
\hline Average cycle length (years): & & & 3.6 & 2.1 & 1.4 \\
\hline Median cycle length (years): & & & 3.6 & 2.2 & 1.4 \\
\hline St. dev. & & & 1.0 & 0.9 & 0.5 \\
\hline \multicolumn{6}{|c|}{ Peaks } \\
\hline Country & Number & $\begin{array}{r}\text { Time (\% share } \\
\text { of total time) }\end{array}$ & $\begin{array}{r}\text { Duration } \\
\text { (number of } \\
\text { quarters) }\end{array}$ & $\begin{array}{r}\text { Amplitude } \\
(\% \text { change } \\
\text { between peak }\end{array}$ & $\begin{array}{r}\text { Slope } \\
\text { (amplitude/dura } \\
\text { tion) }\end{array}$ \\
\hline 1 Argentina & 12 & 39.8 & 7.8 & 42.8 & 5.5 \\
\hline 2 Brazil & 4 & 65.4 & 11.3 & 27.6 & 2.4 \\
\hline 3 Bulgaria & 4 & 42.4 & 9.8 & 47.1 & 4.8 \\
\hline 4 China & 9 & 22.4 & 2.9 & 3.2 & 1.1 \\
\hline 5 Colombia & 3 & 34.6 & 6.0 & 16.1 & 2.7 \\
\hline 6 Croatia & 3 & 29.8 & 7.0 & 5.3 & 0.8 \\
\hline 7 Hungary & 5 & 55.6 & 15.0 & 30.9 & 2.1 \\
\hline 8 India & 16 & 33.9 & 5.2 & 32.0 & 6.2 \\
\hline 9 Indonesia & 2 & 18.8 & 9.0 & 20.3 & 2.3 \\
\hline 10 Lithuania & 5 & 48.3 & 10.5 & 37.0 & 3.5 \\
\hline 11 Malaysia & 4 & 25.0 & 3.3 & 2.5 & 0.8 \\
\hline 12 Mexico & 3 & 46.2 & 12.0 & 20.2 & 1.7 \\
\hline 13 Philippines & 3 & 38.5 & 6.7 & 11.8 & 1.8 \\
\hline 14 Poland & 6 & 44.8 & 8.7 & 23.1 & 2.7 \\
\hline 15 Russia & 4 & 62.5 & 11.7 & 18.3 & 1.6 \\
\hline 16 Serbia & 5 & 38.5 & 4.0 & 15.0 & 3.8 \\
\hline 17 SouthAfrica & 4 & 42.3 & 5.5 & 5.5 & 1.0 \\
\hline 18 Thailand & 4 & 38.5 & 6.7 & 8.2 & 1.2 \\
\hline 19 Turkey & 2 & 44.2 & 11.5 & 51.2 & 4.5 \\
\hline 20 Ukraine & 3 & 46.2 & 12.0 & 42.0 & 3.5 \\
\hline 21 Uruguay & 3 & 53.8 & 9.3 & 21.8 & 2.3 \\
\hline 22 Latvia & 3 & 61.0 & 16.7 & 58.4 & 3.5 \\
\hline 23 Kazakhstan & 5 & 46.2 & 6.0 & 16.0 & 2.7 \\
\hline 24 Romania & 3 & 38.5 & 10.0 & 31.4 & 3.1 \\
\hline 25 Vietnam & 5 & 57.7 & 6.0 & 41.6 & 6.9 \\
\hline mean & 4.8 & 43.0 & 8.6 & 25.2 & 2.9 \\
\hline median & 4.0 & 42.4 & 8.7 & 21.8 & 2.7 \\
\hline st. dev. & 3.2 & 12.1 & 3.5 & 15.8 & 1.7 \\
\hline sum & 120 & & & & \\
\hline
\end{tabular}


Table 3B. LTDR Cycles (EM)

Troughs

\begin{tabular}{|c|c|c|c|c|c|}
\hline Country & Number & $\begin{array}{r}\text { Time (\% share } \\
\text { of total time) }\end{array}$ & $\begin{array}{r}\text { Duration } \\
\text { (number of } \\
\text { quarters) }\end{array}$ & $\begin{array}{r}\text { Amplitude } \\
\text { (\% change } \\
\text { between peak } \\
\text { and trough) } \\
\end{array}$ & $\begin{array}{r}\text { Slope } \\
\text { (amplitude/dura } \\
\text { tion) }\end{array}$ \\
\hline 1 Argentina & 11 & 53.7 & 10.5 & -47.4 & -4.5 \\
\hline 2 Brazil & 3 & 23.1 & 4.0 & -11.7 & -2.9 \\
\hline 3 Bulgaria & 4 & 17.4 & 5.3 & -37.6 & -7.1 \\
\hline 4 China & 10 & 63.8 & 8.2 & -10.6 & -1.3 \\
\hline 5 Colombia & 4 & 48.1 & 8.3 & -15.2 & -1.8 \\
\hline 6 Croatia & 2 & 19.1 & 4.5 & -6.9 & -1.5 \\
\hline 7 Hungary & 4 & 25.9 & 7.0 & -33.9 & -4.8 \\
\hline 8 India & 15 & 44.8 & 6.9 & -35.0 & -5.1 \\
\hline 9 Indonesia & 2 & 16.7 & 4.0 & -5.6 & -1.4 \\
\hline 10 Lithuania & 4 & 21.8 & 4.8 & -24.1 & -5.1 \\
\hline 11 Malaysia & 5 & 48.1 & 6.3 & -6.2 & -1.0 \\
\hline 12 Mexico & 2 & 38.5 & 10.0 & -11.1 & -1.1 \\
\hline 13 Philippines & 4 & 38.5 & 6.7 & -15.2 & -2.3 \\
\hline 14 Poland & 7 & 37.1 & 7.2 & -13.1 & -1.8 \\
\hline 15 Russia & 3 & 23.2 & 4.3 & -12.7 & -2.9 \\
\hline 16 Serbia & 5 & 36.5 & 4.8 & -11.8 & -2.5 \\
\hline 17 SouthAfrica & 5 & 44.2 & 5.8 & -5.8 & -1.0 \\
\hline 18 Thailand & 4 & 36.5 & 4.8 & -6.7 & -1.4 \\
\hline 19 Turkey & 3 & 9.6 & 2.5 & -5.6 & -2.2 \\
\hline 20 Ukraine & 3 & 40.4 & 7.0 & -22.7 & -3.2 \\
\hline 21 Uruguay & 3 & 23.1 & 6.0 & -34.4 & -5.7 \\
\hline 22 Latvia & 3 & 7.3 & 3.0 & -22.0 & -7.3 \\
\hline 23 Kazakhstan & 4 & 44.2 & 5.8 & -16.6 & -2.9 \\
\hline 24 Romania & 2 & 15.4 & 4.0 & -7.9 & -2.0 \\
\hline 25 Vietnam & 5 & 21.2 & 2.8 & -10.9 & -4.0 \\
\hline mean & 4.7 & 31.9 & 5.8 & -17.2 & -3.1 \\
\hline median & 4.0 & 36.5 & 5.8 & -12.7 & -2.5 \\
\hline st. dev. & 3.1 & 14.7 & 2.1 & 11.9 & 1.9 \\
\hline sum & 117 & & & & \\
\hline
\end{tabular}


Table 4A. Equity Price Cycles (AM)

\begin{tabular}{|c|c|c|c|c|c|}
\hline Number of cycles & 231 & & total & peak & trough \\
\hline \multicolumn{2}{|c|}{ Average cycle length (years): } & & 3.8 & 2.3 & 1.4 \\
\hline \multicolumn{2}{|c|}{ Median cycle length (years): } & & 3.5 & 2.2 & 1.3 \\
\hline \multicolumn{2}{|c|}{ St. dev. } & & 0.9 & 0.8 & 0.4 \\
\hline \multicolumn{6}{|c|}{ Peaks } \\
\hline Country & Number & $\begin{array}{r}\text { Time }(\% \text { share } \\
\text { of total time) }\end{array}$ & 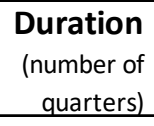 & $\begin{array}{r}\text { Amplitude } \\
\text { (\% change } \\
\text { between peak } \\
\end{array}$ & $\begin{array}{r}\text { Slope } \\
\text { (amplitude/dura } \\
\text { tion) }\end{array}$ \\
\hline 1 Australia & 13 & 51.7 & 7.8 & 44.0 & 5.7 \\
\hline 2 Austria & 13 & 41.7 & 6.3 & 53.2 & 8.5 \\
\hline 3 Belgium & 10 & 59.4 & 10.7 & 65.3 & 6.1 \\
\hline 4 Canada & 11 & 66.7 & 10.9 & 55.7 & 5.1 \\
\hline 5 Cyprus & 2 & 7.5 & 3.0 & 62.0 & 20.7 \\
\hline 6 Czech Republic & 3 & 51.6 & 11.0 & 117.3 & 10.7 \\
\hline 7 Denmark & 13 & 60.0 & 8.3 & 55.7 & 6.7 \\
\hline 8 Estonia & 4 & 36.0 & 6.0 & 61.8 & 10.3 \\
\hline 9 Finland & 5 & 49.1 & 13.3 & 133.7 & 10.1 \\
\hline 10 France & 13 & 57.2 & 7.9 & 53.1 & 6.7 \\
\hline 11 Germany & 7 & 50.5 & 8.0 & 53.3 & 6.7 \\
\hline 12 Greece & 3 & 32.8 & 10.5 & 109.2 & 10.4 \\
\hline 13 Hong Kong SAR & 8 & 45.6 & 8.9 & 68.5 & 7.7 \\
\hline 14 Iceland & 5 & 71.6 & 12.6 & 82.1 & 6.5 \\
\hline 15 Ireland & 3 & 56.3 & 13.3 & 55.8 & 4.2 \\
\hline 16 Israel & 4 & 46.7 & 11.7 & 86.2 & 7.4 \\
\hline 17 Italy & 11 & 46.1 & 7.5 & 53.2 & 7.1 \\
\hline 18 Japan & 12 & 59.4 & 8.9 & 63.6 & 7.1 \\
\hline 19 Korea & 4 & 48.4 & 10.3 & 96.0 & 9.3 \\
\hline 20 Luxembourg & 4 & 38.1 & 8.0 & 64.0 & 8.0 \\
\hline 21 Malta & 5 & 56.6 & 8.6 & 57.3 & 6.7 \\
\hline 22 Netherlands & 7 & 70.0 & 18.0 & 87.0 & 4.8 \\
\hline 23 New Zealand & 5 & 46.3 & 10.0 & 60.3 & 6.0 \\
\hline 24 Norway & 15 & 53.9 & 6.5 & 60.5 & 9.4 \\
\hline 25 Portugal & 8 & 39.8 & 5.4 & 44.3 & 8.2 \\
\hline 26 Singapore & 8 & 51.4 & 8.1 & 64.0 & 7.9 \\
\hline 27 Slovak Republic & 4 & 41.4 & 6.0 & 41.1 & 6.8 \\
\hline 28 Slovenia & 4 & 44.0 & 5.5 & 54.4 & 9.9 \\
\hline 29 Spain & 11 & 50.0 & 8.2 & 57.9 & 7.1 \\
\hline 30 Sweden & 9 & 49.4 & 11.1 & 79.9 & 7.2 \\
\hline 31 Switzerland & 7 & 62.8 & 16.1 & 79.9 & 4.9 \\
\hline 32 Taiwan Province of China & 4 & 43.8 & 9.3 & 66.0 & 7.1 \\
\hline 33 United Kingdom & 6 & 56.1 & 10.0 & 46.9 & 4.7 \\
\hline 34 United States & 10 & 58.3 & 10.5 & 44.2 & 4.2 \\
\hline mean & 7.4 & 50.0 & 9.4 & 67.0 & 7.6 \\
\hline median & 7.0 & 50.3 & 8.9 & 61.2 & 7.1 \\
\hline st. dev. & 3.7 & 11.9 & 3.1 & 21.5 & 2.9 \\
\hline sum & 251 & & & & \\
\hline
\end{tabular}


Table 4A. Equity Price Cycles (AM)

Troughs

\begin{tabular}{|c|c|c|c|c|c|}
\hline Country & Number & $\begin{array}{r}\text { Time }(\% \text { share } \\
\text { of total time) }\end{array}$ & $\begin{array}{r}\text { Duration } \\
\text { (number of } \\
\text { quarters) }\end{array}$ & $\begin{array}{r}\text { Amplitude } \\
\text { (\% change } \\
\text { between peak } \\
\text { and trough) } \\
\end{array}$ & $\begin{array}{r}\text { Slope } \\
\text { (amplitude/dura } \\
\text { tion) }\end{array}$ \\
\hline 1 Australia & 13 & 34 & 5 & -37 & -8 \\
\hline 2 Austria & 12 & 47 & 7 & -42 & -6 \\
\hline 3 Belgium & 11 & 29 & 5 & -42 & -8 \\
\hline 4 Canada & 12 & 29 & 5 & -37 & -8 \\
\hline 5 Cyprus & 2 & 50 & 10 & -234 & -23 \\
\hline 6 Czech Republic & 4 & 22 & 5 & -51 & -11 \\
\hline 7 Denmark & 14 & 29 & 4 & -34 & -8 \\
\hline 8 Estonia & 3 & 28 & 5 & -74 & -16 \\
\hline 9 Finland & 5 & 38 & 8 & -88 & -11 \\
\hline 10 France & 14 & 32 & 4 & -39 & -9 \\
\hline 11 Germany & 7 & 25 & 3 & -35 & -10 \\
\hline 12 Greece & 3 & 48 & 10 & -160 & -15 \\
\hline 13 Hong Kong SAR & 8 & 25 & 4 & -45 & -11 \\
\hline 14 Iceland & 5 & 20 & 5 & -101 & -22 \\
\hline 15 Ireland & 3 & 21 & 8 & -107 & -14 \\
\hline 16 Israel & 4 & 29 & 6 & -44 & -8 \\
\hline 17 Italy & 12 & 32 & 5 & -45 & -9 \\
\hline 18 Japan & 12 & 36 & 6 & -43 & -7 \\
\hline 19 Korea & 4 & 36 & 6 & -56 & -10 \\
\hline 20 Luxembourg & 4 & 44 & 7 & -75 & -11 \\
\hline 21 Malta & 5 & 36 & 7 & -49 & -7 \\
\hline 22 Netherlands & 8 & 22 & 6 & -45 & -8 \\
\hline 23 New Zealand & 6 & 19 & 4 & -46 & -11 \\
\hline 24 Norway & 16 & 42 & 5 & -45 & -9 \\
\hline 25 Portugal & 9 & 45 & 6 & -47 & -8 \\
\hline 26 Singapore & 8 & 36 & 5 & -41 & -8 \\
\hline 27 Slovak Republic & 5 & 41 & 6 & -34 & -6 \\
\hline 28 Slovenia & 5 & 32 & 4 & -53 & -13 \\
\hline 29 Spain & 12 & 42 & 7 & -57 & -8 \\
\hline 30 Sweden & 9 & 30 & 6 & -48 & -8 \\
\hline 31 Switzerland & 8 & 23 & 6 & -39 & -7 \\
\hline 32 Taiwan Province of China & 4 & 30 & 5 & -57 & -12 \\
\hline 33 United Kingdom & 7 & 25 & 5 & -31 & -7 \\
\hline 34 United States & 11 & 28 & 5 & -30 & -6 \\
\hline mean & 7.8 & 32.6 & 5.7 & -59.1 & -10.1 \\
\hline median & 7.5 & 30.8 & 5.3 & -45.3 & -8.4 \\
\hline st. dev. & 3.9 & 8.6 & 1.6 & 40.6 & 4.1 \\
\hline sum & 265 & & & & \\
\hline
\end{tabular}


Table 4B. Equity Price Cycles (EM)

\begin{tabular}{|c|c|c|c|c|c|}
\hline Number of cycles & 125 & & total & peak & trough \\
\hline Average cycle length (years): & & & 3.2 & 1.8 & 1.4 \\
\hline Median cycle length (years): & & & 3.1 & 1.8 & 1.3 \\
\hline St. dev. & & & 0.6 & 0.6 & 0.3 \\
\hline \multicolumn{6}{|c|}{ Peaks } \\
\hline Country & Number & $\begin{array}{r}\text { Time (\% share } \\
\text { of total time) }\end{array}$ & $\begin{array}{r}\text { Duration } \\
\text { (number of } \\
\text { quarters) } \\
\end{array}$ & $\begin{array}{r}\text { Amplitude } \\
\text { (\% change } \\
\text { between peak }\end{array}$ & $\begin{array}{r}\text { Slope } \\
\text { (amplitude/dura } \\
\text { tion) } \\
\end{array}$ \\
\hline 1 Argentina & 7 & 52.5 & 8.8 & 85.0 & 9.6 \\
\hline 2 Brazil & 8 & 55.0 & 6.9 & 88.2 & 12.8 \\
\hline 3 Bulgaria & 5 & 30.4 & 4.3 & 46.4 & 10.9 \\
\hline 4 China & 8 & 39.6 & 5.4 & 63.5 & 11.7 \\
\hline 5 Colombia & 3 & 22.6 & 6.0 & 40.6 & 6.8 \\
\hline 6 Croatia & 5 & 43.3 & 6.5 & 56.0 & 8.6 \\
\hline 7 Hungary & 8 & 46.3 & 5.5 & 62.8 & 11.4 \\
\hline 8 India & 7 & 43.3 & 7.0 & 56.7 & 8.1 \\
\hline 9 Indonesia & 8 & 53.2 & 8.4 & 81.4 & 9.7 \\
\hline 10 Lithuania & 4 & 47.5 & 9.3 & 106.8 & 11.4 \\
\hline 11 Malaysia & 12 & 51.0 & 7.0 & 45.9 & 6.6 \\
\hline 12 Mexico & 8 & 53.0 & 6.3 & 49.6 & 7.9 \\
\hline 13 Philippines & 5 & 54.2 & 7.8 & 61.7 & 7.9 \\
\hline 14 Poland & 5 & 58.5 & 11.0 & 111.1 & 10.1 \\
\hline 15 Russia & 4 & 53.6 & 9.3 & 99.0 & 10.7 \\
\hline 16 Serbia & 3 & 19.4 & 2.3 & 60.6 & 26.0 \\
\hline 17 SouthAfrica & 5 & 43.6 & 8.5 & 58.0 & 6.8 \\
\hline 18 Thailand & 8 & 46.8 & 7.3 & 58.7 & 8.1 \\
\hline 19 Turkey & 9 & 51.4 & 6.1 & 88.0 & 14.4 \\
\hline 20 Ukraine & 3 & 52.2 & 11.7 & 173.2 & 14.8 \\
\hline \multicolumn{6}{|l|}{21 Uruguay } \\
\hline 22 Latvia & 6 & 49.2 & 5.8 & 43.2 & 7.4 \\
\hline 23 Kazakhstan & 3 & 43.9 & 8.3 & 135.8 & 16.3 \\
\hline 24 Romania & 3 & 47.8 & 11.0 & 106.9 & 9.7 \\
\hline 25 Vietnam & 4 & 22.8 & 4.3 & 87.2 & 20.1 \\
\hline mean & 5.9 & 45.0 & 7.3 & 77.8 & 11.2 \\
\hline median & 5.0 & 47.6 & 7.0 & 63.2 & 9.9 \\
\hline st. dev. & 2.4 & 10.8 & 2.3 & 32.4 & 4.6 \\
\hline sum & 141 & & & & \\
\hline
\end{tabular}


Table 4B. Equity Price Cycles (EM)

Troughs

\begin{tabular}{|c|c|c|c|c|c|}
\hline Country & Number & $\begin{array}{r}\text { Time }(\% \text { share } \\
\text { of total time) }\end{array}$ & $\begin{array}{r}\text { Duration } \\
\text { (number of } \\
\text { quarters) }\end{array}$ & $\begin{array}{r}\text { Amplitude } \\
\text { (\% change } \\
\text { between peak } \\
\text { and trough) } \\
\end{array}$ & $\begin{array}{r}\text { Slope } \\
\text { (amplitude/dura } \\
\text { tion) }\end{array}$ \\
\hline 1 Argentina & 7 & 38.6 & 5.6 & -102.0 & -18.3 \\
\hline 2 Brazil & 9 & 38.0 & 4.8 & -50.6 & -10.6 \\
\hline 3 Bulgaria & 4 & 33.9 & 4.8 & -66.3 & -14.0 \\
\hline 4 China & 8 & 51.0 & 6.1 & -48.5 & -7.9 \\
\hline 5 Colombia & 3 & 35.8 & 6.3 & -32.1 & -5.1 \\
\hline 6 Croatia & 5 & 36.7 & 4.4 & -44.3 & -10.1 \\
\hline 7 Hungary & 9 & 42.1 & 5.0 & -46.8 & -9.4 \\
\hline 8 India & 7 & 45.4 & 6.3 & -48.9 & -7.8 \\
\hline 9 Indonesia & 9 & 33.3 & 5.3 & -60.4 & -11.5 \\
\hline 10 Lithuania & 4 & 27.1 & 4.0 & -59.1 & -14.8 \\
\hline 11 Malaysia & 11 & 35.1 & 4.8 & -42.3 & -8.8 \\
\hline 12 Mexico & 8 & 41.0 & 4.3 & -31.8 & -7.5 \\
\hline 13 Philippines & 6 & 30.6 & 4.4 & -32.7 & -7.4 \\
\hline 14 Poland & 6 & 24.5 & 4.6 & -69.4 & -15.1 \\
\hline 15 Russia & 5 & 36.2 & 6.3 & -62.6 & -10.0 \\
\hline 16 Serbia & 4 & 50.0 & 6.0 & -104.6 & -17.4 \\
\hline 17 SouthAfrica & 5 & 33.3 & 5.2 & -35.9 & -6.9 \\
\hline 18 Thailand & 8 & 40.4 & 5.5 & -58.2 & -10.6 \\
\hline 19 Turkey & 10 & 43.0 & 5.1 & -72.6 & -14.2 \\
\hline 20 Ukraine & 4 & 31.3 & 7.0 & -125.5 & -17.9 \\
\hline \multicolumn{6}{|l|}{21 Uruguay } \\
\hline 22 Latvia & 5 & 32.2 & 3.8 & -39.7 & -10.5 \\
\hline 23 Kazakhstan & 4 & 45.6 & 8.7 & -94.7 & -10.9 \\
\hline 24 Romania & 4 & 29.0 & 6.7 & -80.7 & -12.1 \\
\hline 25 Vietnam & 4 & 56.1 & 8.0 & -93.3 & -11.7 \\
\hline mean & 6.2 & 37.9 & 5.5 & -62.6 & -11.3 \\
\hline median & 5.5 & 36.4 & 5.2 & -58.6 & -10.6 \\
\hline st. dev. & 2.3 & 7.8 & 1.2 & 25.8 & 3.6 \\
\hline sum & 149 & & & & \\
\hline
\end{tabular}


Table 5A. Property Price Cycles (AM)

\begin{tabular}{|c|c|c|c|c|c|}
\hline Number of cycles & 166 & & total & peak & trough \\
\hline Average cycle length (years): & & & 5.2 & 3.0 & 2.2 \\
\hline Median cycle length (years): & & & 4.7 & 2.7 & 2.0 \\
\hline St. dev. & & & 2.0 & 1.3 & 1.5 \\
\hline \multicolumn{6}{|c|}{ Peaks } \\
\hline Country & Number & $\begin{array}{r}\text { Time (\% share } \\
\text { of total time) }\end{array}$ & $\begin{array}{r}\text { Duration } \\
\text { (number of } \\
\text { quarters) } \\
\end{array}$ & $\begin{array}{r}\text { Amplitude } \\
\text { (\% change } \\
\text { between peak }\end{array}$ & $\begin{array}{r}\text { Slope } \\
\text { (amplitude/dura } \\
\text { tion) }\end{array}$ \\
\hline 1 Australia & 11 & 53.1 & 9.5 & 15.7 & 1.7 \\
\hline 2 Austria & 4 & 62.7 & 9.3 & 10.3 & 1.1 \\
\hline 3 Belgium & 7 & 71.9 & 18.3 & 23.4 & 1.3 \\
\hline 4 Canada & 10 & 49.7 & 9.9 & 16.5 & 1.7 \\
\hline \multicolumn{6}{|l|}{5 Cyprus } \\
\hline 6 Czech Republic & 2 & 20.6 & 13.0 & 42.4 & 3.3 \\
\hline 7 Denmark & 8 & 56.7 & 12.6 & 25.0 & 2.0 \\
\hline 8 Estonia & 5 & 62.0 & 8.8 & 45.4 & 5.2 \\
\hline 9 Finland & 8 & 53.1 & 13.6 & 26.2 & 1.9 \\
\hline 10 France & 6 & 62.6 & 18.7 & 25.3 & 1.4 \\
\hline 11 Germany & 8 & 25.7 & 6.6 & 4.8 & 0.7 \\
\hline 12 Greece & 2 & 18.3 & 13.0 & 21.3 & 1.6 \\
\hline 13 Hong Kong SAR & 7 & 48.3 & 7.0 & 30.4 & 4.3 \\
\hline 14 Iceland & 4 & 44.1 & 8.7 & 19.8 & 2.3 \\
\hline 15 Ireland & 9 & 57.5 & 12.9 & 27.2 & 2.1 \\
\hline 16 Israel & 6 & 51.5 & 8.5 & 17.7 & 2.1 \\
\hline 17 Italy & 10 & 51.1 & 10.1 & 24.1 & 2.4 \\
\hline 18 Japan & 3 & 31.3 & 28.0 & 30.2 & 1.1 \\
\hline 19 Korea & 7 & 38.3 & 6.3 & 9.8 & 1.6 \\
\hline \multicolumn{6}{|l|}{20 Luxembourg } \\
\hline 21 Malta & 4 & 12.1 & 2.3 & 3.8 & 1.6 \\
\hline 22 Netherlands & 7 & 64.2 & 19.2 & 31.1 & 1.6 \\
\hline 23 New Zealand & 10 & 51.7 & 9.2 & 21.7 & 2.4 \\
\hline 24 Norway & 8 & 57.5 & 12.9 & 25.0 & 1.9 \\
\hline 25 Portugal & 5 & 39.3 & 10.5 & 9.3 & 0.9 \\
\hline 26 Singapore & 5 & 53.5 & 10.6 & 43.7 & 4.1 \\
\hline \multicolumn{6}{|l|}{27 Slovak Republic } \\
\hline 28 Slovenia & 4 & 40.3 & 7.8 & 13.8 & 1.8 \\
\hline 29 Spain & 8 & 52.0 & 11.4 & 29.0 & 2.5 \\
\hline 30 Sweden & 7 & 57.0 & 17.0 & 25.9 & 1.5 \\
\hline 31 Switzerland & 7 & 40.8 & 12.2 & 13.0 & 1.1 \\
\hline \multicolumn{6}{|l|}{32 Taiwan Province of China } \\
\hline 33 United Kingdom & 7 & 57.5 & 14.7 & 36.7 & 2.5 \\
\hline 34 United States & 6 & 53.6 & 19.2 & 16.5 & 0.9 \\
\hline mean & 6.5 & 47.9 & 12.0 & 22.8 & 2.0 \\
\hline median & 7.0 & 51.8 & 11.0 & 23.7 & 1.7 \\
\hline st. dev. & 2.4 & 14.4 & 5.1 & 10.7 & 1.0 \\
\hline sum & 195 & & & & \\
\hline
\end{tabular}


Table 5A. Property Price Cycles (AM) Troughs

\begin{tabular}{|c|c|c|c|c|c|}
\hline Country & Number & $\begin{array}{r}\text { Time (\% share } \\
\text { of total time) }\end{array}$ & $\begin{array}{r}\text { Duration } \\
\text { (number of } \\
\text { quarters) }\end{array}$ & $\begin{array}{r}\text { Amplitude } \\
\text { (\% change } \\
\text { between peak } \\
\text { and trough) } \\
\end{array}$ & $\begin{array}{r}\text { Slope } \\
\text { (amplitude/dura } \\
\text { tion) }\end{array}$ \\
\hline 1 Australia & 11 & 33 & 5 & -6 & -1 \\
\hline 2 Austria & 5 & 29 & 4 & -5 & -1 \\
\hline 3 Belgium & 7 & 22 & 7 & -9 & -1 \\
\hline 4 Canada & 10 & 32 & 6 & -8 & -1 \\
\hline \multicolumn{6}{|l|}{5 Cyprus } \\
\hline 6 Czech Republic & 2 & 41 & 13 & -22 & -2 \\
\hline 7 Denmark & 9 & 37 & 8 & -18 & -2 \\
\hline 8 Estonia & 5 & 30 & 5 & -28 & -5 \\
\hline 9 Finland & 7 & 35 & 9 & -18 & -2 \\
\hline 10 France & 6 & 27 & 10 & -10 & -1 \\
\hline 11 Germany & 8 & 56 & 13 & -7 & -1 \\
\hline 12 Greece & 1 & 7 & 5 & -2 & 0 \\
\hline 13 Hong Kong SAR & 6 & 41 & 6 & -24 & -4 \\
\hline 14 Iceland & 4 & 37 & 6 & -11 & -2 \\
\hline 15 Ireland & 9 & 34 & 7 & -14 & -2 \\
\hline 16 Israel & 7 & 33 & 6 & -6 & -1 \\
\hline 17 Italy & 9 & 33 & 7 & -16 & -2 \\
\hline 18 Japan & 2 & 43 & 39 & -44 & -1 \\
\hline 19 Korea & 8 & 55 & 9 & -13 & -1 \\
\hline \multicolumn{6}{|l|}{20 Luxembourg } \\
\hline 21 Malta & 4 & 36 & 5 & -8 & -2 \\
\hline 22 Netherlands & 7 & 31 & 8 & -15 & -2 \\
\hline 23 New Zealand & 11 & 36 & 6 & -10 & -2 \\
\hline 24 Norway & 9 & 35 & 8 & -11 & -1 \\
\hline 25 Portugal & 4 & 40 & 11 & -7 & -1 \\
\hline 26 Singapore & 5 & 37 & 9 & -30 & -3 \\
\hline \multicolumn{6}{|l|}{27 Slovak Republic } \\
\hline 28 Slovenia & 4 & 31 & 8 & -11 & -1 \\
\hline 29 Spain & 8 & 29 & 7 & -12 & -2 \\
\hline 30 Sweden & 7 & 36 & 9 & -14 & -2 \\
\hline 31 Switzerland & 7 & 37 & 10 & -14 & -1 \\
\hline \multicolumn{6}{|c|}{32 Taiwan Province of China } \\
\hline 33 United Kingdom & 8 & 34 & 9 & -16 & -2 \\
\hline 34 United States & 6 & 31 & 9 & -9 & -1 \\
\hline mean & 6.5 & 34.6 & 8.7 & -14.0 & -1.7 \\
\hline median & 7.0 & 34.4 & 7.8 & -11.7 & -1.5 \\
\hline st. dev. & 2.6 & 8.7 & 6.0 & 8.7 & 1.0 \\
\hline sum & 196 & & & & \\
\hline
\end{tabular}


Table 5B. Property Price Cycles (EM)

\begin{tabular}{|c|c|c|c|c|c|}
\hline \multicolumn{3}{|c|}{ Number of cycles $\quad 42$} & total & peak & trough \\
\hline \multicolumn{3}{|c|}{ Average cycle length (years): } & 4.1 & 1.9 & 2.2 \\
\hline \multicolumn{3}{|c|}{ Median cycle length (years): } & 3.6 & 1.8 & 1.9 \\
\hline \multicolumn{2}{|c|}{ St. dev. } & & 1.6 & 1.1 & 1.2 \\
\hline \multicolumn{6}{|c|}{ Peaks } \\
\hline Country & Number & $\begin{array}{r}\text { Time (\% share } \\
\text { of total time) }\end{array}$ & $\begin{array}{r}\text { Duration } \\
\text { (number of } \\
\text { quarters) } \\
\end{array}$ & $\begin{array}{r}\text { Amplitude } \\
\text { (\% change } \\
\text { between peak }\end{array}$ & $\begin{array}{r}\text { Slope } \\
\text { (amplitude/dura } \\
\text { tion) }\end{array}$ \\
\hline 1 Argentina & 5 & 56.2 & 10.0 & 20.4 & 2.0 \\
\hline \multicolumn{6}{|l|}{2 Brazil } \\
\hline 3 Bulgaria & 4 & 44.3 & 8.8 & 35.5 & 4.1 \\
\hline 4 China & 3 & 40.4 & 9.5 & 22.1 & 2.3 \\
\hline 5 Colombia & 2 & 15.3 & 7.5 & 12.1 & 1.6 \\
\hline \multicolumn{6}{|l|}{6 Croatia } \\
\hline 7 Hungary & 2 & 4.5 & 3.0 & 2.6 & 0.9 \\
\hline \multicolumn{6}{|l|}{8 India } \\
\hline 9 Indonesia & 4 & 21.7 & 4.5 & 4.6 & 1.0 \\
\hline \multicolumn{6}{|l|}{10 Lithuania } \\
\hline 11 Malaysia & 4 & 32.8 & 4.8 & 3.3 & 0.7 \\
\hline 12 Mexico & 3 & 15.4 & 3.0 & 1.7 & 0.6 \\
\hline 13 Philippines & 4 & 24.1 & 6.3 & 9.4 & 1.5 \\
\hline 14 Poland & 2 & 12.9 & 4.0 & 4.9 & 1.2 \\
\hline 15 Russia & 3 & 69.5 & 13.7 & 47.5 & 3.5 \\
\hline 16 Serbia & 4 & 43.3 & 8.7 & 18.5 & 2.1 \\
\hline 17 SouthAfrica & 4 & 57.6 & 8.5 & 28.4 & 3.3 \\
\hline 18 Thailand & 6 & 34.7 & 6.6 & 8.9 & 1.3 \\
\hline \multicolumn{6}{|l|}{19 Turkey } \\
\hline 20 Ukraine & 2 & 67.2 & 19.5 & 118.0 & 6.0 \\
\hline 21 Uruguay & 4 & 47.3 & 6.5 & 19.4 & 3.0 \\
\hline \multicolumn{6}{|l|}{22 Latvia } \\
\hline \multicolumn{6}{|l|}{23 Kazakhstan } \\
\hline \multicolumn{6}{|l|}{24 Romania } \\
\hline \multicolumn{6}{|l|}{25 Vietnam } \\
\hline mean & 3.5 & 36.7 & 7.8 & 22.3 & 2.2 \\
\hline median & 4.0 & 37.6 & 7.1 & 15.3 & 1.8 \\
\hline st. dev. & 1.2 & 19.9 & 4.2 & 28.6 & 1.5 \\
\hline sum & 56 & & & & \\
\hline
\end{tabular}


Table 5B. Property Price Cycles (EM) Troughs

\begin{tabular}{|c|c|c|c|c|c|}
\hline Country & Number & $\begin{array}{r}\text { Time (\% share } \\
\text { of total time) }\end{array}$ & $\begin{array}{r}\text { Duration } \\
\text { (number of } \\
\text { quarters) }\end{array}$ & $\begin{array}{r}\text { Amplitude } \\
\text { (\% change } \\
\text { between peak } \\
\text { and trough) }\end{array}$ & $\begin{array}{r}\text { Slope } \\
\text { (amplitude/dura } \\
\text { tion) }\end{array}$ \\
\hline 1 Argentina & 5 & 18.0 & 4.0 & -19.8 & -4.9 \\
\hline \multicolumn{6}{|l|}{2 Brazil } \\
\hline 3 Bulgaria & 4 & 48.1 & 12.7 & -49.6 & -3.9 \\
\hline 4 China & 2 & 34.0 & 8.0 & -7.9 & -1.0 \\
\hline 5 Colombia & 3 & 28.6 & 14.0 & -24.6 & -1.8 \\
\hline \multicolumn{6}{|l|}{6 Croatia } \\
\hline 7 Hungary & 2 & 54.5 & 18.0 & -28.7 & -1.6 \\
\hline 8 India & 1 & & & & \\
\hline 9 Indonesia & 5 & 42.2 & 8.8 & -7.8 & -0.9 \\
\hline \multicolumn{6}{|l|}{10 Lithuania } \\
\hline 11 Malaysia & 5 & 20.7 & 3.0 & -2.2 & -0.7 \\
\hline 12 Mexico & 3 & 38.5 & 5.0 & -2.0 & -0.4 \\
\hline 13 Philippines & 4 & 57.0 & 11.3 & -22.8 & -2.0 \\
\hline 14 Poland & 1 & 54.8 & 17.0 & -32.1 & -1.9 \\
\hline 15 Russia & 3 & 13.6 & 4.0 & -26.2 & -6.6 \\
\hline 16 Serbia & 4 & 43.3 & 6.5 & -27.6 & -4.2 \\
\hline 17 SouthAfrica & 4 & 32.2 & 6.3 & -9.7 & -1.5 \\
\hline 18 Thailand & 6 & 44.2 & 7.0 & -12.0 & -1.7 \\
\hline \multicolumn{6}{|l|}{19 Turkey } \\
\hline 20 Ukraine & 2 & 17.2 & 10.0 & -69.1 & -6.9 \\
\hline 21 Uruguay & 5 & 25.5 & 3.5 & -16.0 & -4.6 \\
\hline \multicolumn{6}{|l|}{22 Latvia } \\
\hline \multicolumn{6}{|l|}{23 Kazakhstan } \\
\hline \multicolumn{6}{|l|}{24 Romania } \\
\hline \multicolumn{6}{|l|}{25 Vietnam } \\
\hline mean & 3.5 & 35.8 & 8.7 & -22.4 & -2.8 \\
\hline median & 4.0 & 36.3 & 7.5 & -21.3 & -1.8 \\
\hline st. dev. & 1.5 & 14.3 & 4.8 & 17.6 & 2.1 \\
\hline sum & 59 & & & & \\
\hline
\end{tabular}


Table 6A. GDP Cycles (AM)

\begin{tabular}{|c|c|c|c|c|c|}
\hline Number of cycles & 126 & & total & peak & trough \\
\hline \multicolumn{2}{|c|}{ Average cycle length (years): } & & 6.7 & 5.7 & 1.1 \\
\hline \multicolumn{2}{|l|}{ Median cycle length (years): } & & 5.9 & 4.9 & 1.1 \\
\hline \multicolumn{2}{|l|}{ St. dev. } & & 3.0 & 2.9 & 0.3 \\
\hline \multicolumn{6}{|c|}{ Peaks } \\
\hline Country & Number & $\begin{array}{r}\text { Time (\% share } \\
\text { of total time) }\end{array}$ & $\begin{array}{r}\text { Duration } \\
\text { (number of } \\
\text { quarters) } \\
\end{array}$ & $\begin{array}{r}\text { Amplitude } \\
\text { (\% change } \\
\text { between peak }\end{array}$ & $\begin{array}{r}\text { Slope } \\
\text { (amplitude/dura } \\
\text { tion) }\end{array}$ \\
\hline 1 Australia & 7 & 46.4 & 17.0 & 20.0 & 1.2 \\
\hline 2 Austria & 4 & 68.8 & 25.0 & 15.7 & 0.6 \\
\hline 3 Belgium & 4 & 81.6 & 28.8 & 17.5 & 0.6 \\
\hline 4 Canada & 3 & 45.8 & 49.5 & 38.7 & 0.8 \\
\hline 5 Cyprus & 2 & 7.5 & 6.0 & 2.9 & 0.5 \\
\hline 6 Czech Republic & 5 & 67.0 & 16.8 & 17.0 & 1.0 \\
\hline 7 Denmark & 4 & 66.7 & 16.0 & 11.1 & 0.7 \\
\hline 8 Estonia & 3 & 56.8 & 25.0 & 47.1 & 1.9 \\
\hline 9 Finland & 6 & 78.1 & 20.8 & 19.0 & 0.9 \\
\hline 10 France & 5 & 60.5 & 33.3 & 20.7 & 0.6 \\
\hline 11 Germany & 11 & 70.9 & 15.6 & 12.1 & 0.8 \\
\hline 12 Greece & 11 & 59.4 & 10.7 & 12.5 & 1.2 \\
\hline 13 Hong Kong SAR & 7 & 69.6 & 19.5 & 35.9 & 1.8 \\
\hline 14 Iceland & 3 & 70.8 & 17.0 & 21.8 & 1.3 \\
\hline 15 Ireland & 2 & 25.0 & 18.0 & 8.7 & 0.5 \\
\hline \multicolumn{6}{|l|}{16 Israel } \\
\hline 17 Italy & 8 & 72.1 & 14.0 & 7.7 & 0.5 \\
\hline 18 Japan & 7 & 45.7 & 10.7 & 6.2 & 0.6 \\
\hline 19 Korea & 3 & 48.9 & 54.0 & 103.9 & 1.9 \\
\hline 20 Luxembourg & 3 & 45.6 & 18.0 & 18.4 & 1.0 \\
\hline 21 Malta & 3 & 41.7 & 12.5 & 11.3 & 0.9 \\
\hline 22 Netherlands & 4 & 78.3 & 29.8 & 21.8 & 0.7 \\
\hline 23 New Zealand & 5 & 67.6 & 15.0 & 14.5 & 1.0 \\
\hline 24 Norway & 5 & 70.3 & 26.0 & 23.7 & 0.9 \\
\hline 25 Portugal & 4 & 35.0 & 9.3 & 4.2 & 0.4 \\
\hline 26 Singapore & 5 & 49.7 & 20.0 & 42.3 & 2.1 \\
\hline 27 Slovak Republic & 2 & 54.2 & 19.5 & 31.0 & 1.6 \\
\hline 28 Slovenia & 2 & 70.0 & 35.0 & 35.9 & 1.0 \\
\hline 29 Spain & 4 & 75.9 & 35.7 & 28.9 & 0.8 \\
\hline 30 Sweden & 2 & 9.1 & 8.0 & 9.5 & 1.2 \\
\hline 31 Switzerland & 6 & 65.0 & 15.2 & 10.2 & 0.7 \\
\hline 32 Taiwan Province of China & 4 & 64.1 & 46.3 & 87.1 & 1.9 \\
\hline 33 United Kingdom & 6 & 68.3 & 30.2 & 25.0 & 0.8 \\
\hline 34 United States & 6 & 79.2 & 29.2 & 28.0 & 1.0 \\
\hline mean & 4.7 & 58.0 & 22.6 & 24.6 & 1.0 \\
\hline median & 4.0 & 65.0 & 19.5 & 19.0 & 0.9 \\
\hline st. dev. & 2.3 & 18.7 & 11.8 & 21.5 & 0.5 \\
\hline sum & 156 & & & & \\
\hline
\end{tabular}


Table 6A. GDP Cycles (AM) Troughs

\begin{tabular}{|c|c|c|c|c|c|}
\hline Country & Number & $\begin{array}{r}\text { Time (\% share } \\
\text { of total time) }\end{array}$ & $\begin{array}{r}\text { Duration } \\
\text { (number of } \\
\text { quarters) }\end{array}$ & $\begin{array}{r}\text { Amplitude } \\
\text { (\% change } \\
\text { between peak } \\
\text { and trough) } \\
\end{array}$ & $\begin{array}{r}\text { Slope } \\
\text { (amplitude/dura } \\
\text { tion) } \\
\end{array}$ \\
\hline 1 Australia & 7 & 10 & 3 & -2 & -1 \\
\hline 2 Austria & 3 & 10 & 4 & -2 & -1 \\
\hline 3 Belgium & 5 & 9 & 3 & -2 & -1 \\
\hline 4 Canada & 3 & 6 & 4 & -4 & -1 \\
\hline 5 Cyprus & 1 & 6 & 5 & -3 & -1 \\
\hline 6 Czech Republic & 5 & 22 & 4 & -8 & -2 \\
\hline 7 Denmark & 5 & 23 & 6 & -3 & -1 \\
\hline 8 Estonia & 3 & 16 & 5 & -11 & -2 \\
\hline 9 Finland & 7 & 18 & 5 & -5 & -1 \\
\hline 10 France & 5 & 10 & 4 & -2 & 0 \\
\hline 11 Germany & 10 & 16 & 4 & -2 & -1 \\
\hline 12 Greece & 11 & 30 & 5 & -7 & -1 \\
\hline 13 Hong Kong SAR & 7 & 14 & 3 & -4 & -1 \\
\hline 14 Iceland & 4 & 18 & 4 & -6 & -1 \\
\hline 15 Ireland & 1 & 11 & 8 & -13 & -2 \\
\hline \multicolumn{6}{|l|}{16 Israel } \\
\hline 17 Italy & 7 & 21 & 4 & -2 & -1 \\
\hline 18 Japan & 6 & 14 & 3 & -3 & -1 \\
\hline 19 Korea & 3 & 5 & 4 & -5 & -1 \\
\hline 20 Luxembourg & 3 & 13 & 3 & -4 & -1 \\
\hline 21 Malta & 3 & 13 & 3 & -3 & -1 \\
\hline 22 Netherlands & 5 & 12 & 5 & -3 & -1 \\
\hline 23 New Zealand & 6 & 14 & 3 & -3 & -1 \\
\hline 24 Norway & 5 & 16 & 5 & -2 & -1 \\
\hline 25 Portugal & 3 & 24 & 6 & -5 & -1 \\
\hline 26 Singapore & 5 & 10 & 3 & -5 & -2 \\
\hline 27 Slovak Republic & 3 & 8 & 3 & -7 & -2 \\
\hline 28 Slovenia & 3 & 11 & 6 & -7 & -1 \\
\hline 29 Spain & 4 & 16 & 6 & -3 & -1 \\
\hline 30 Sweden & 2 & 14 & 6 & -4 & -1 \\
\hline 31 Switzerland & 7 & 16 & 4 & -2 & -1 \\
\hline 32 Taiwan Province of China & 4 & 6 & 3 & -4 & -1 \\
\hline 33 United Kingdom & 6 & 12 & 5 & -4 & -1 \\
\hline 34 United States & 7 & 9 & 3 & -2 & -1 \\
\hline \multicolumn{6}{|l|}{35 Euro Area } \\
\hline mean & 4.8 & 13.7 & 4.3 & -4.4 & -1.0 \\
\hline median & 5.0 & 13.3 & 4.2 & -3.8 & -0.8 \\
\hline st. dev. & 2.3 & 5.8 & 1.2 & 2.6 & 0.5 \\
\hline sum & 159 & & & & \\
\hline
\end{tabular}


Table 6B. GDP Cycles (EM)

\begin{tabular}{|c|c|c|c|c|c|}
\hline Number of cycles & 37 & & total & peak & trough \\
\hline Average cycle length (years): & & & 6.3 & 5.3 & 1.0 \\
\hline Median cycle length (years): & & & 5.5 & 4.6 & 0.9 \\
\hline St. dev. & & & 2.3 & 2.3 & 0.2 \\
\hline \multicolumn{6}{|c|}{ Peaks } \\
\hline Country & Number & $\begin{array}{l}\text { Time (\% share } \\
\text { of total time) }\end{array}$ & $\begin{array}{r}\text { Duration } \\
\text { (number of } \\
\text { quarters) } \\
\end{array}$ & $\begin{array}{r}\text { Amplitude } \\
\text { (\% change } \\
\text { between peak }\end{array}$ & $\begin{array}{r}\text { Slope } \\
\text { (amplitude/dura } \\
\text { tion) }\end{array}$ \\
\hline 1 Argentina & 4 & 62.5 & 18.3 & 29.6 & 1.6 \\
\hline 2 Brazil & 7 & 74.0 & 12.3 & 14.1 & 1.1 \\
\hline \multicolumn{6}{|l|}{3 Bulgaria } \\
\hline \multicolumn{6}{|l|}{4 China } \\
\hline \multicolumn{6}{|l|}{5 Colombia } \\
\hline \multicolumn{6}{|l|}{6 Croatia } \\
\hline 7 Hungary & 3 & 71.3 & 19.0 & 15.7 & 0.8 \\
\hline 8 India & 6 & 76.4 & 33.6 & 50.7 & 1.5 \\
\hline 9 Indonesia & 2 & 8.6 & 11.0 & 21.0 & 1.9 \\
\hline \multicolumn{6}{|l|}{10 Lithuania } \\
\hline 11 Malaysia & 2 & 41.7 & 40.0 & 56.0 & 1.4 \\
\hline 12 Mexico & 6 & 60.7 & 17.0 & 16.9 & 1.0 \\
\hline \multicolumn{6}{|l|}{13 Philippines } \\
\hline \multicolumn{6}{|l|}{14 Poland } \\
\hline 15 Russia & 3 & 55.0 & 22.0 & 38.0 & 1.7 \\
\hline \multicolumn{6}{|l|}{16 Serbia } \\
\hline 17 SouthAfrica & 7 & 46.8 & 17.2 & 16.4 & 1.0 \\
\hline 18 Thailand & 3 & 63.6 & 28.0 & 35.7 & 1.3 \\
\hline 19 Turkey & 5 & 57.1 & 16.0 & 28.9 & 1.8 \\
\hline \multicolumn{6}{|l|}{20 Ukraine } \\
\hline \multicolumn{6}{|l|}{21 Uruguay } \\
\hline \multicolumn{6}{|l|}{22 Latvia } \\
\hline \multicolumn{6}{|l|}{23 Kazakhstan } \\
\hline \multicolumn{6}{|l|}{24 Romania } \\
\hline \multicolumn{6}{|l|}{25 Vietnam } \\
\hline mean & 4.4 & 56.2 & 21.3 & 29.3 & 1.4 \\
\hline median & 4.0 & 60.7 & 18.3 & 28.9 & 1.4 \\
\hline st. dev. & 1.9 & 19.1 & 9.0 & 14.5 & 0.4 \\
\hline sum & 48 & & & & \\
\hline
\end{tabular}


Table 6B. GDP Cycles (EM)

Troughs

\begin{tabular}{|c|c|c|c|c|c|}
\hline Country & Number & $\begin{array}{r}\text { Time (\% share } \\
\text { of total time) }\end{array}$ & $\begin{array}{r}\text { Duration } \\
\text { (number of } \\
\text { quarters) }\end{array}$ & $\begin{array}{r}\text { Amplitude } \\
\text { (\% change } \\
\text { between peak } \\
\text { and trough) }\end{array}$ & $\begin{array}{r}\text { Slope } \\
\text { (amplitude/dura } \\
\text { tion) }\end{array}$ \\
\hline 1 Argentina & 4 & 25.0 & 5.5 & -7.9 & -1.4 \\
\hline 2 Brazil & 6 & 16.0 & 2.7 & -2.9 & -1.1 \\
\hline \multicolumn{6}{|l|}{3 Bulgaria } \\
\hline \multicolumn{6}{|l|}{4 China } \\
\hline \multicolumn{6}{|l|}{5 Colombia } \\
\hline \multicolumn{6}{|l|}{6 Croatia } \\
\hline 7 Hungary & 4 & 13.8 & 3.7 & -4.0 & -1.1 \\
\hline 8 India & 6 & 9.5 & 3.5 & -3.5 & -1.0 \\
\hline 9 Indonesia & 2 & 5.5 & 3.5 & -10.4 & -3.0 \\
\hline \multicolumn{6}{|l|}{10 Lithuania } \\
\hline 11 Malaysia & 2 & 5.2 & 2.5 & -9.1 & -3.6 \\
\hline 12 Mexico & 6 & 17.9 & 4.2 & -5.3 & -1.3 \\
\hline \multicolumn{6}{|l|}{13 Philippines } \\
\hline \multicolumn{6}{|l|}{14 Poland } \\
\hline 15 Russia & 3 & 13.8 & 3.7 & -9.2 & -2.5 \\
\hline \multicolumn{6}{|l|}{16 Serbia } \\
\hline 17 SouthAfrica & 7 & 16.4 & 5.1 & -2.7 & -0.5 \\
\hline 18 Thailand & 3 & 15.9 & 4.7 & -8.5 & -1.8 \\
\hline 19 Turkey & 5 & 18.8 & 4.2 & -10.1 & -2.4 \\
\hline \multicolumn{6}{|l|}{20 Ukraine } \\
\hline \multicolumn{6}{|l|}{21 Uruguay } \\
\hline \multicolumn{6}{|l|}{22 Latvia } \\
\hline \multicolumn{6}{|l|}{23 Kazakhstan } \\
\hline \multicolumn{6}{|l|}{24 Romania } \\
\hline \multicolumn{6}{|l|}{25 Vietnam } \\
\hline mean & 4.4 & 14.3 & 3.9 & -6.7 & -1.8 \\
\hline median & 4.0 & 15.9 & 3.7 & -7.9 & -1.4 \\
\hline st. dev. & 1.7 & 5.8 & 0.9 & 3.0 & 1.0 \\
\hline sum & 48 & & & & \\
\hline
\end{tabular}




\section{Appendix 3. Country-Specific Results on Cycle Length}

Figure 1. Average Cycle Length by Country (Years)
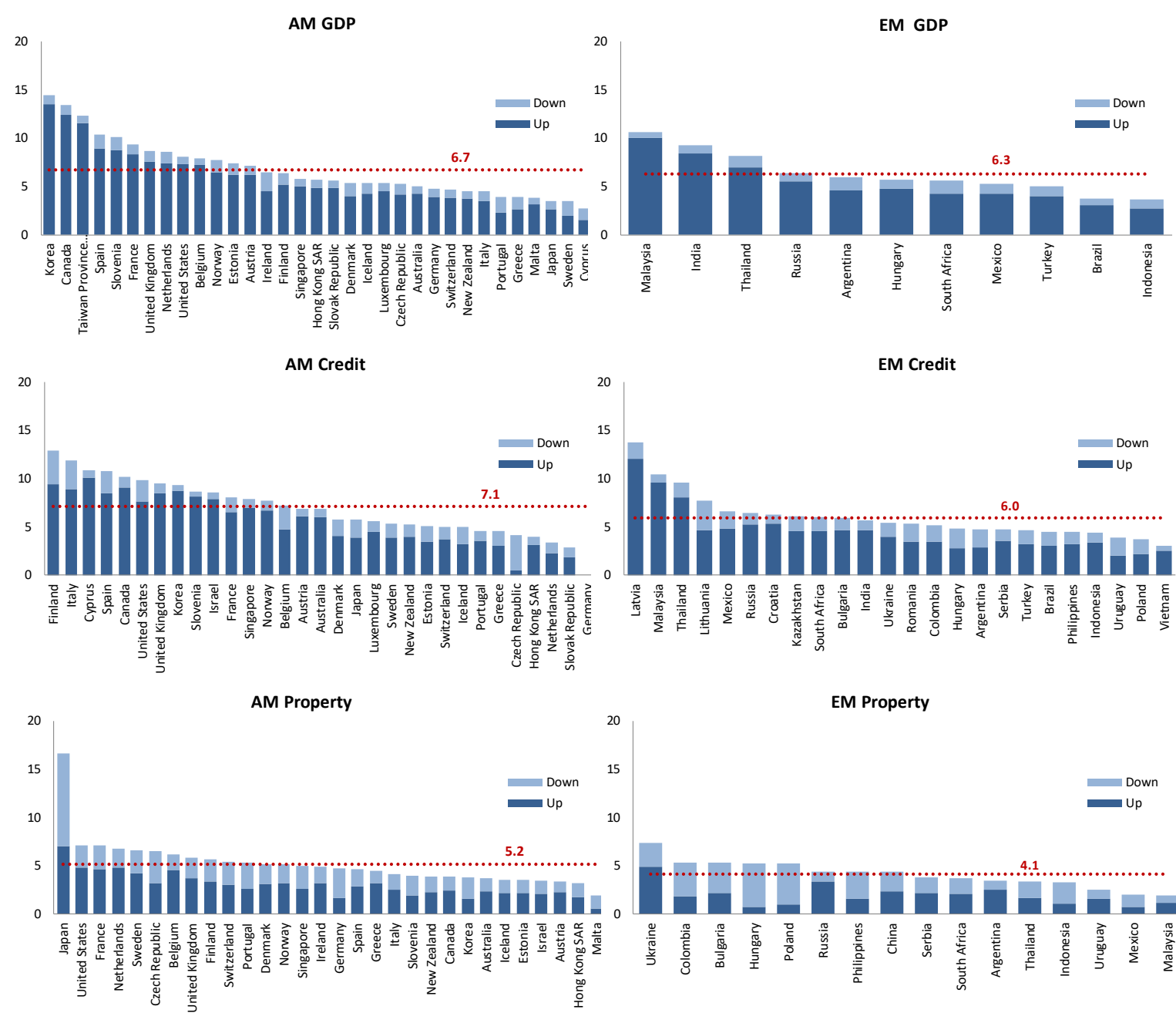

EM Property

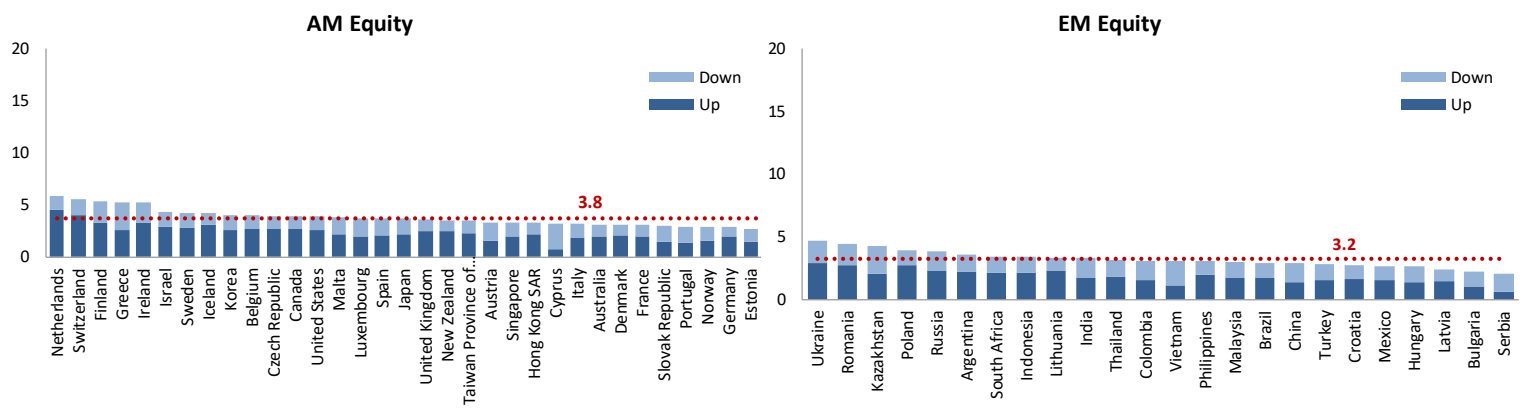


Figure 2. Distribution of Cycle Length (AM)
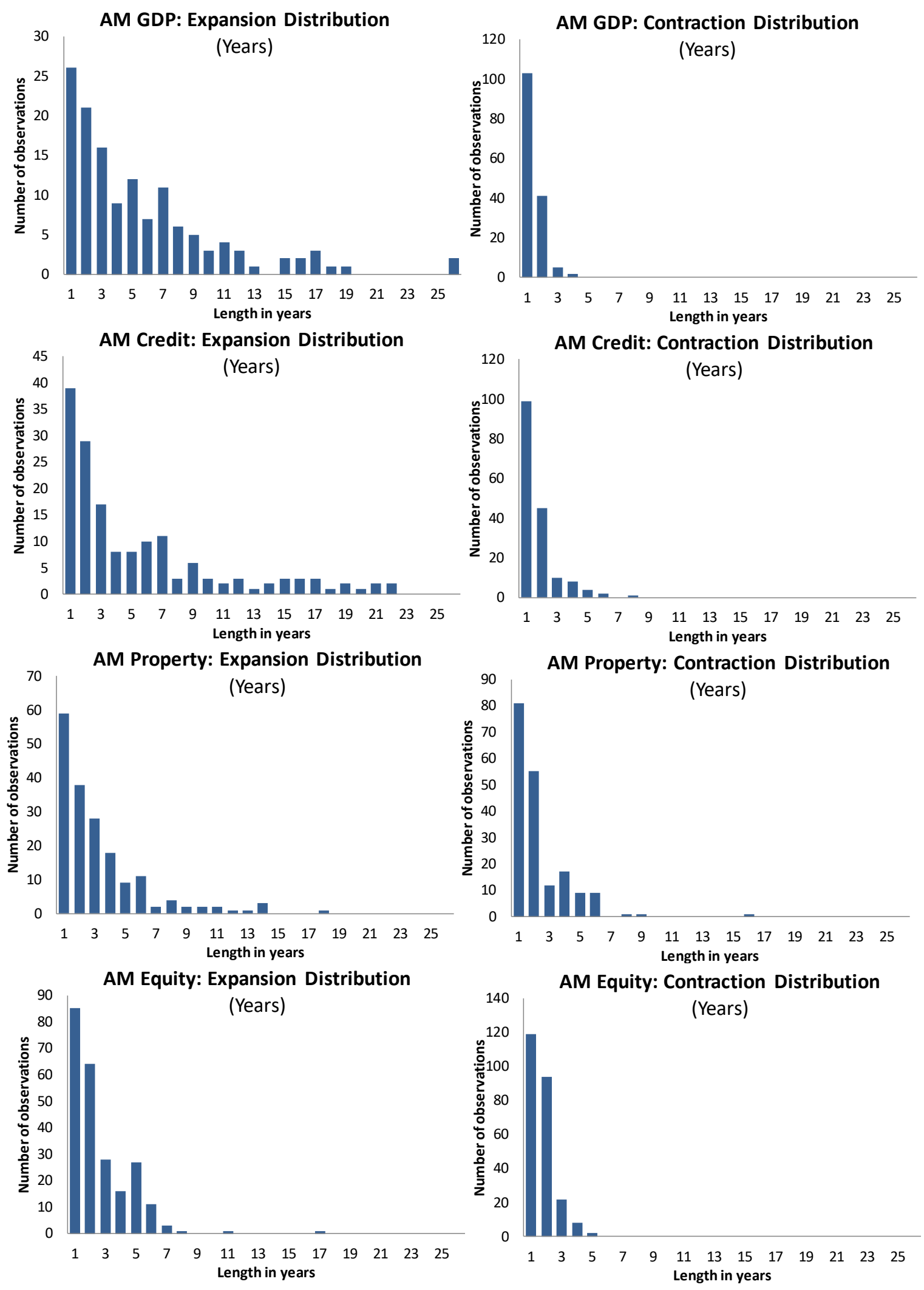
Figure 3. Distribution of Cycle Length (EM)
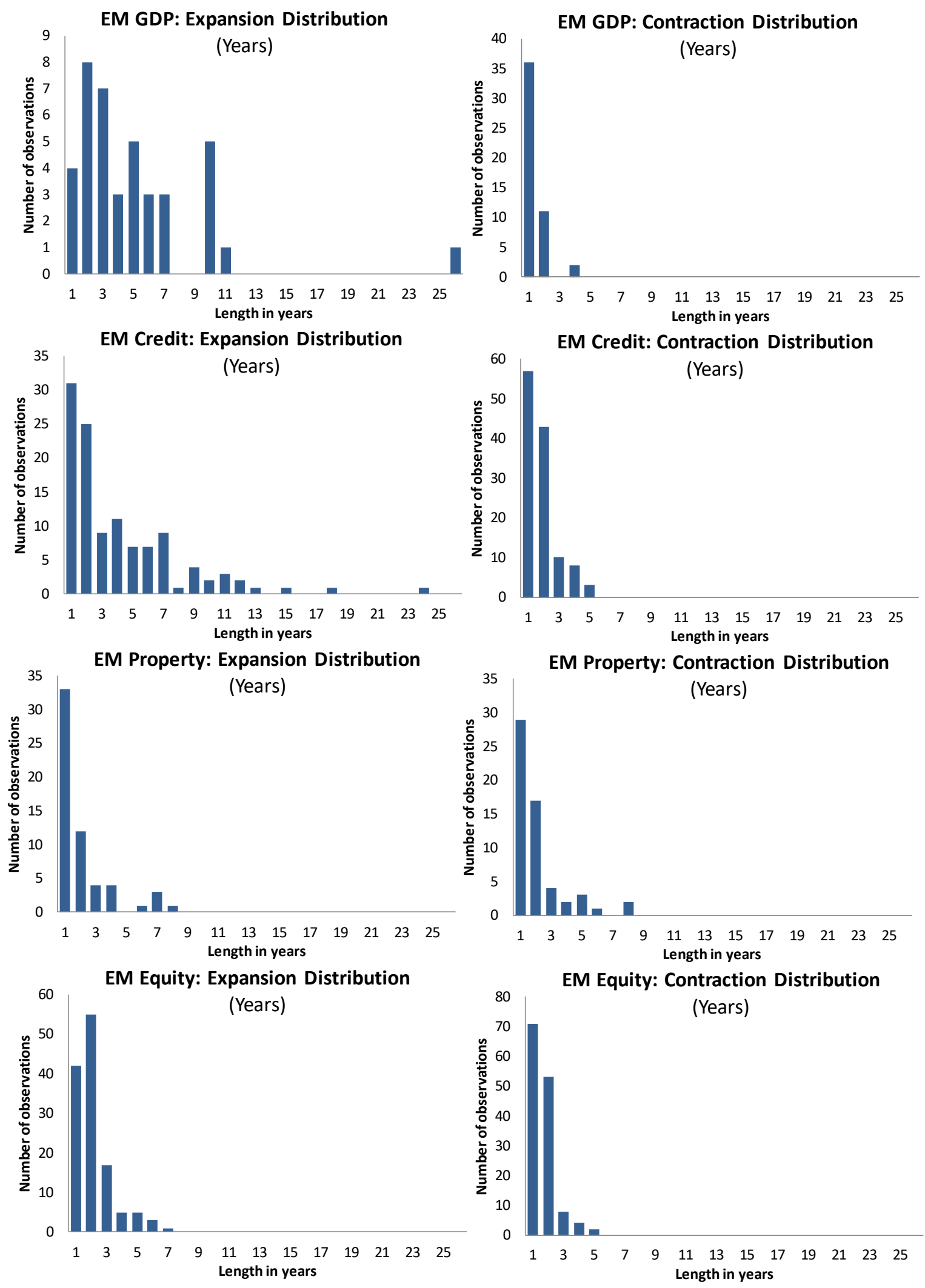


\section{Appendix 4. Synchronization across Financial and Real Cycles}

The extent of synchronization across cycles - the fraction of time the two series are in the same phase of their respective cycles - is measured using the concordance index developed by Harding and Pagan (2002b):

$$
\left\{C I_{x y}\right\}=\frac{1}{T} \sum_{t=1}^{T}\left[C_{t}^{x} C_{t}^{y}+\left(1-C_{t}^{x}\right)\left(1-C_{t}^{y}\right)\right]
$$

where:

$$
\begin{aligned}
& C_{t}^{x}=\{0, \text { if } x \text { is downturn at time } t \mid 1, \text { if } x \text { is in upturn at time } t\} \\
& C_{t}^{y}=\{0 \text {, if } y \text { is downturn at time } t \mid 1, \text { if } y \text { is in upturn at time } t\}
\end{aligned}
$$

On average, financial cycles tend to be more synchronized in AMs rather than EMs. This is especially the case for property price, credit and equity cycle and between leverage cycle and equity price (Table 1).

In terms of synchronization between financial and business cycles, we find that output and consumption tend to be more synchronized with credit, reflecting the fact that expansions in lending tend to boost consumption and correspondingly, output, given the large share of consumption in GDP. Investments tend to more synchronized with equity markets, which are an important source of corporate financing.

These findings have two implications. First, they underscore the interaction between financial and business cycles and raise the possibilities for spillovers. Second, financial and business cycles are not perfectly synchronized, with the fraction of time the two cycles are in the same phase being 60 percent on average. This means there is scope for macroprudential policy to supplement monetary policy in achieving financial stability goals. 
Table 1. Synchronization across Cycles within a Country

(Fraction of time the two series are in the same phase of their respective cycles)

\section{Advanced markets}

\begin{tabular}{c|cccc} 
& Credit & Property & Equity & LTDR \\
\hline Credit & $\ldots$ & 0.65 & 0.57 & 0.58 \\
Property & & $\ldots$ & 0.56 & 0.55 \\
Equity & & & $\ldots$ & 0.56 \\
LTDR & & & & $\ldots$ \\
& & & & \\
GDP & 0.66 & 0.60 & 0.65 & 0.61 \\
C & 0.70 & 0.57 & 0.60 & 0.56 \\
I & 0.63 & 0.58 & 0.66 & 0.57
\end{tabular}

\section{Emerging markets}

\begin{tabular}{c|cccc} 
& Credit & Property & Equity & LTDR \\
\hline Credit & $\ldots$ & 0.51 & 0.60 & 0.55 \\
Property & & $\ldots$ & 0.47 & 0.55 \\
Equity & & & $\ldots$ & 0.44 \\
LTDR & & & & $\ldots$ \\
& & & & \\
GDP & 0.64 & 0.31 & 0.57 & 0.61 \\
C & 0.65 & 0.40 & 0.58 & 0.60 \\
I & 0.53 & 0.56 & 0.64 & 0.60
\end{tabular}


Table 2A. Synchronization of Financial Cycles within a Country (AM) (Fraction of time the two series are in the same phase of their respective cycles)

\begin{tabular}{|c|c|c|c|c|c|c|}
\hline & \multicolumn{3}{|c|}{ Credit with: } & \multicolumn{2}{|c|}{ Property with: } & \multirow{2}{*}{$\frac{\text { Equity with: }}{\text { LTDR }}$} \\
\hline & property & equity & LTDR & equity & LTDR & \\
\hline \multicolumn{7}{|l|}{ Advanced markets } \\
\hline 1 Australia & 0.50 & 0.49 & 0.62 & 0.60 & 0.68 & 0.53 \\
\hline 2 Austria & 0.22 & 0.49 & 0.65 & 0.54 & 0.40 & 0.47 \\
\hline 3 Belgium & 0.74 & 0.69 & 0.58 & 0.66 & 0.53 & 0.36 \\
\hline 4 Canada & 0.72 & 0.64 & 0.64 & 0.66 & 0.46 & 0.58 \\
\hline 5 Cyprus & 0.88 & 0.88 & 0.63 & 0.97 & 0.53 & 0.54 \\
\hline 6 Czech Republic & 0.74 & 0.25 & 0.25 & 0.21 & 0.23 & 0.97 \\
\hline 7 Denmark & 0.73 & 0.63 & 0.50 & 0.65 & 0.52 & 0.42 \\
\hline 8 Estonia & 0.74 & 0.35 & 0.40 & 0.26 & 0.22 & 0.82 \\
\hline 9 Finland & 0.68 & 0.67 & 0.70 & 0.73 & 0.63 & 0.45 \\
\hline 10 France & 0.77 & 0.58 & 0.65 & 0.56 & 0.59 & 0.39 \\
\hline 11 Germany & 0.61 & 0.80 & 0.70 & 0.47 & 0.63 & 0.56 \\
\hline 12 Greece & 0.64 & 0.61 & 0.63 & 0.88 & 0.51 & 0.46 \\
\hline 13 Hong Kong SAR & 0.82 & 0.79 & 0.26 & 0.79 & 0.30 & 0.25 \\
\hline 14 Iceland & 0.51 & 0.66 & 0.58 & 0.31 & 0.59 & 0.51 \\
\hline 15 Ireland & 0.77 & 0.15 & 0.54 & 0.37 & 0.69 & 0.56 \\
\hline 16 Israel & 0.38 & 0.82 & 0.25 & 0.40 & 0.74 & 0.23 \\
\hline 17 Italy & 0.64 & 0.55 & 0.60 & 0.57 & 0.64 & 0.63 \\
\hline 18 Japan & 0.70 & 0.64 & 0.52 & 0.56 & 0.72 & 0.49 \\
\hline 19 Korea & 0.33 & 0.84 & 0.65 & 0.30 & 0.54 & 0.60 \\
\hline 20 Luxembourg & 0.80 & 0.22 & 0.22 & 0.19 & 0.16 & 0.87 \\
\hline 21 Malta & 0.89 & 0.22 & 0.16 & 0.23 & 0.12 & 0.75 \\
\hline 22 Netherlands & 0.75 & 0.77 & 0.93 & 0.68 & 0.68 & 0.70 \\
\hline 23 New Zealand & 0.71 & 0.54 & 0.86 & 0.75 & 0.68 & 0.59 \\
\hline 24 Norway & 0.61 & 0.66 & 0.80 & 0.62 & 0.49 & 0.56 \\
\hline 25 Portugal & 0.57 & 0.51 & 0.66 & 0.27 & 0.44 & 0.61 \\
\hline 26 Singapore & 0.30 & 0.67 & 0.66 & 0.43 & 0.46 & 0.47 \\
\hline 27 Slovak Republic & 0.75 & 0.79 & 0.95 & 0.87 & 0.77 & 0.82 \\
\hline 28 Slovenia & 0.28 & 0.22 & 0.36 & 0.89 & 0.88 & 0.83 \\
\hline 29 Spain & 0.67 & 0.50 & 0.70 & 0.61 & 0.74 & 0.53 \\
\hline 30 Sweden & 0.57 & 0.51 & 0.63 & 0.63 & 0.60 & 0.52 \\
\hline 31 Switzerland & 0.72 & 0.75 & 0.61 & 0.60 & 0.63 & 0.60 \\
\hline 32 United Kingdom & 0.70 & 0.40 & 0.55 & 0.49 & 0.61 & 0.44 \\
\hline 33 United States & 0.89 & 0.67 & 0.67 & 0.72 & 0.66 & 0.47 \\
\hline mean & 0.65 & 0.57 & 0.58 & 0.56 & 0.55 & 0.56 \\
\hline median & 0.70 & 0.63 & 0.63 & 0.60 & 0.59 & 0.54 \\
\hline st. dev. & 0.18 & 0.20 & 0.19 & 0.21 & 0.18 & 0.17 \\
\hline
\end{tabular}


Table 2B. Synchronization of Financial Cycles within a Country (EM)

(Fraction of time the two series are in the same phase of their respective cycles)

\begin{tabular}{|c|c|c|c|c|c|c|}
\hline & \multicolumn{3}{|c|}{ Credit with: } & \multicolumn{2}{|c|}{ Property with: } & \multirow{2}{*}{$\frac{\text { Equity with }}{\text { LTDR }}$} \\
\hline & property & equity & LTDR & equity & LTDR & \\
\hline \multicolumn{7}{|c|}{ Emerging markets } \\
\hline 1 Argentina & 0.64 & 0.39 & 0.50 & 0.29 & 0.55 & 0.45 \\
\hline 2 Brazil & 0.66 & 0.53 & 0.42 & 0.69 & 0.08 & 0.25 \\
\hline 3 Bulgaria & 0.82 & 0.26 & 0.88 & 0.22 & 0.87 & 0.28 \\
\hline 4 China & 0.51 & 0.70 & 0.45 & 0.70 & 0.20 & 0.31 \\
\hline 5 Colombia & 0.53 & 0.58 & 0.44 & 0.21 & 0.82 & 0.09 \\
\hline 6 Croatia & 0.10 & 0.85 & 0.93 & 0.13 & 0.11 & 0.88 \\
\hline 7 Hungary & 0.74 & 0.35 & 0.94 & 0.30 & 0.75 & 0.32 \\
\hline 8 India & 0.41 & 0.58 & 0.41 & 0.28 & 0.65 & 0.42 \\
\hline 9 Indonesia & 0.26 & 0.29 & 0.82 & 0.63 & 0.19 & 0.35 \\
\hline 10 Lithuania & 0.88 & 0.84 & 0.93 & 0.92 & 0.87 & 0.83 \\
\hline 11 Malaysia & 0.29 & 0.55 & 0.32 & 0.37 & 0.83 & 0.31 \\
\hline 12 Mexico & 0.62 & 0.58 & 0.56 & 0.84 & 0.88 & 0.78 \\
\hline 13 Philippines & 0.82 & 0.22 & 0.22 & 0.22 & 0.31 & 0.80 \\
\hline 14 Poland & 0.65 & 0.50 & 0.57 & 0.32 & 0.35 & 0.76 \\
\hline 15 Russia & 0.32 & 0.24 & 0.88 & 0.84 & 0.25 & 0.17 \\
\hline 16 Serbia & 0.22 & 0.79 & 0.87 & 0.18 & 0.24 & 0.86 \\
\hline 17 SouthAfrica & 0.38 & 0.75 & 0.32 & 0.27 & 0.88 & 0.23 \\
\hline 18 Thailand & 0.83 & 0.71 & 0.77 & 0.78 & 0.71 & 0.70 \\
\hline 19 Turkey & 0.40 & 0.51 & 0.53 & 0.69 & 0.87 & 0.73 \\
\hline 20 Ukraine & 0.82 & 0.75 & 0.29 & 0.87 & 0.15 & 0.22 \\
\hline 21 Latvia & 0.17 & 0.80 & 0.41 & 0.12 & 0.72 & 0.25 \\
\hline 22 Kazakhstan & 0.31 & 0.80 & 0.32 & 0.26 & 0.94 & 0.20 \\
\hline 23 Romania & 0.77 & 0.88 & 0.27 & 0.82 & 0.12 & 0.22 \\
\hline 24 Vietnam & 0.09 & 0.87 & 0.20 & 0.22 & 0.83 & 0.17 \\
\hline mean & 0.51 & 0.60 & 0.55 & 0.47 & 0.55 & 0.44 \\
\hline median & 0.52 & 0.58 & 0.48 & 0.31 & 0.68 & 0.32 \\
\hline st. dev. & 0.25 & 0.22 & 0.26 & 0.28 & 0.32 & 0.27 \\
\hline
\end{tabular}


Table 3A. Synchronization of Financial and Real Cycles within a Country (AM) (Fraction of time the two series are in the same phase of their respective cycles)

\begin{tabular}{|c|c|c|c|c|c|c|c|c|c|c|c|c|}
\hline & \multicolumn{4}{|c|}{ GDP with: } & \multicolumn{4}{|c|}{ Consumption with: } & \multicolumn{4}{|c|}{ Investment with: } \\
\hline & credit & property & equity & LTDR & credit & property & equity & LTDR & credit & property & equity & LTDR \\
\hline \multicolumn{13}{|l|}{ Advanced markets } \\
\hline 1 Australia & 0.88 & 0.54 & 0.48 & 0.55 & 0.56 & 0.72 & 0.67 & 0.78 & 0.40 & 0.70 & 0.63 & 0.60 \\
\hline 2 Austria & 0.82 & 0.21 & 0.57 & 0.59 & 0.88 & 0.20 & 0.51 & 0.58 & 0.87 & 0.20 & 0.57 & 0.69 \\
\hline 3 Belgium & 0.53 & 0.61 & 0.60 & 0.43 & 0.53 & 0.65 & 0.55 & 0.46 & 0.61 & 0.68 & 0.63 & 0.47 \\
\hline 4 Canada & 0.92 & 0.73 & 0.69 & 0.58 & 0.92 & 0.74 & 0.70 & 0.58 & 0.75 & 0.66 & 0.74 & 0.64 \\
\hline 5 Czech Republic & 0.64 & 0.85 & 0.33 & 0.33 & 0.17 & 0.40 & 0.76 & 0.78 & 0.76 & 0.82 & 0.35 & 0.32 \\
\hline 6 Denmark & 0.53 & 0.69 & 0.55 & 0.56 & 0.64 & 0.67 & 0.63 & 0.42 & 0.63 & 0.58 & 0.63 & 0.49 \\
\hline 7 Estonia & 0.46 & 0.25 & 0.85 & 0.92 & 0.93 & 0.77 & 0.36 & 0.39 & 0.35 & 0.26 & 0.91 & 0.83 \\
\hline 8 Finland & 0.69 & 0.68 & 0.68 & 0.75 & 0.45 & 0.62 & 0.43 & 0.66 & 0.40 & 0.61 & 0.42 & 0.64 \\
\hline 9 France & 0.78 & 0.72 & 0.63 & 0.56 & 0.79 & 0.72 & 0.67 & 0.52 & 0.68 & 0.79 & 0.65 & 0.45 \\
\hline 10 Germany & 0.69 & 0.44 & 0.74 & 0.54 & 0.78 & 0.51 & 0.75 & 0.55 & 0.63 & 0.51 & 0.59 & 0.61 \\
\hline 11 Greece & 0.70 & 0.78 & 0.73 & 0.55 & 0.60 & 0.63 & 0.60 & 0.56 & 0.60 & 0.65 & 0.63 & 0.52 \\
\hline 12 Hong Kong SAR & 0.77 & 0.76 & 0.78 & 0.18 & 0.77 & 0.78 & 0.68 & 0.31 & 0.78 & 0.80 & 0.71 & 0.25 \\
\hline 13 Ireland & 0.14 & 0.37 & 0.78 & 0.59 & 0.96 & 0.74 & 0.18 & 0.51 & 0.31 & 0.54 & 0.80 & 0.72 \\
\hline 14 Israel & 0.18 & 0.72 & 0.18 & 0.91 & 0.83 & 0.35 & 0.79 & 0.23 & 0.74 & 0.31 & 0.85 & 0.23 \\
\hline 15 Italy & 0.74 & 0.61 & 0.52 & 0.65 & 0.74 & 0.63 & 0.58 & 0.65 & 0.64 & 0.61 & 0.70 & 0.79 \\
\hline 16 Japan & 0.73 & 0.53 & 0.65 & 0.33 & 0.70 & 0.53 & 0.69 & 0.33 & 0.56 & 0.58 & 0.60 & 0.65 \\
\hline 17 Korea & 0.87 & 0.34 & 0.83 & 0.63 & 0.87 & 0.27 & 0.88 & 0.63 & 0.79 & 0.49 & 0.77 & 0.55 \\
\hline 18 Luxembourg & 0.20 & 0.07 & 0.87 & 0.83 & 0.24 & 0.11 & 0.86 & 0.85 & 0.26 & 0.22 & 0.80 & 0.74 \\
\hline 19 Netherlands & 0.70 & 0.68 & 0.66 & 0.63 & 0.87 & 0.80 & 0.76 & 0.79 & 0.80 & 0.67 & 0.74 & 0.76 \\
\hline 20 New Zealand & 0.64 & 0.75 & 0.85 & 0.64 & 0.80 & 0.65 & 0.43 & 0.69 & 0.54 & 0.71 & 0.91 & 0.58 \\
\hline 21 Norway & 0.82 & 0.59 & 0.62 & 0.85 & 0.77 & 0.60 & 0.59 & 0.83 & 0.53 & 0.55 & 0.51 & 0.42 \\
\hline 22 Portugal & 0.70 & 0.73 & 0.31 & 0.58 & 0.74 & 0.74 & 0.30 & 0.60 & 0.47 & 0.33 & 0.82 & 0.57 \\
\hline 23 Singapore & 0.78 & 0.37 & 0.81 & 0.58 & 0.79 & 0.37 & 0.78 & 0.63 & 0.58 & 0.60 & 0.59 & 0.47 \\
\hline 24 Slovak Republic & 0.78 & 0.78 & 0.89 & 0.78 & 0.27 & 0.15 & 0.26 & 0.27 & 0.82 & 0.81 & 0.84 & 0.82 \\
\hline 25 Slovenia & 0.43 & 0.78 & 0.71 & 0.81 & 0.91 & 0.25 & 0.20 & 0.30 & 0.88 & 0.32 & 0.27 & 0.34 \\
\hline 26 Spain & 0.79 & 0.66 & 0.59 & 0.65 & 0.64 & 0.74 & 0.69 & 0.67 & 0.82 & 0.71 & 0.59 & 0.66 \\
\hline 27 Sweden & 0.63 & 0.67 & 0.68 & 0.54 & 0.59 & 0.65 & 0.70 & 0.54 & 0.44 & 0.60 & 0.60 & 0.59 \\
\hline 28 Switzerland & 0.68 & 0.58 & 0.61 & 0.56 & 0.71 & 0.61 & 0.72 & 0.55 & 0.84 & 0.68 & 0.77 & 0.60 \\
\hline 29 United Kingdom & 0.85 & 0.73 & 0.50 & 0.57 & 0.85 & 0.75 & 0.50 & 0.57 & 0.61 & 0.68 & 0.52 & 0.50 \\
\hline 30 United States & 0.84 & 0.84 & 0.74 & 0.56 & 0.82 & 0.82 & 0.75 & 0.54 & 0.80 & 0.83 & 0.77 & 0.64 \\
\hline mean & 0.66 & 0.60 & 0.65 & 0.61 & 0.70 & 0.57 & 0.60 & 0.56 & 0.63 & 0.58 & 0.66 & 0.57 \\
\hline median & 0.70 & 0.67 & 0.67 & 0.58 & 0.77 & 0.64 & 0.67 & 0.56 & 0.63 & 0.61 & 0.64 & 0.59 \\
\hline
\end{tabular}


Table 3B. Synchronization of Financial and Real Cycles within a Country (EM) (Fraction of time the two series are in the same phase of their respective cycles)

\begin{tabular}{|c|c|c|c|c|c|c|c|c|c|c|c|c|}
\hline & \multicolumn{4}{|c|}{ GDP with: } & \multicolumn{4}{|c|}{ Consumption with: } & \multicolumn{4}{|c|}{ Investment with: } \\
\hline & credit & property & equity & LTDR & credit & property & equity & LTDR & credit & property & equity & LTDR \\
\hline \multicolumn{13}{|c|}{ Emerging markets } \\
\hline 1 Argentina & 0.42 & 0.23 & 0.78 & 0.52 & 0.40 & 0.25 & 0.77 & 0.51 & 0.42 & 0.23 & 0.80 & 0.52 \\
\hline 2 Brazil & 0.37 & 0.10 & 0.33 & 0.88 & 0.36 & 0.12 & 0.29 & 0.86 & 0.42 & 0.18 & 0.28 & 0.81 \\
\hline 3 China & 0.59 & 0.10 & 0.28 & 0.85 & 0.99 & 0.51 & 0.69 & 0.45 & 0.68 & 0.19 & 0.37 & 0.77 \\
\hline 4 Hungary & 0.49 & 0.30 & 0.79 & 0.46 & 0.51 & 0.31 & 0.79 & 0.47 & 0.50 & 0.36 & 0.84 & 0.45 \\
\hline 5 India & 0.55 & 0.12 & 0.71 & 0.41 & 0.85 & 0.26 & 0.69 & 0.32 & 0.64 & 0.16 & 0.75 & 0.45 \\
\hline 6 Indonesia & 0.93 & 0.29 & 0.36 & 0.77 & 0.89 & 0.33 & 0.35 & 0.73 & 0.50 & 0.68 & 0.68 & 0.50 \\
\hline 7 Malaysia & 0.75 & 0.26 & 0.64 & 0.17 & 0.22 & 0.85 & 0.38 & 0.76 & 0.19 & 0.81 & 0.43 & 0.79 \\
\hline 8 Mexico & 0.73 & 0.83 & 0.72 & 0.75 & 0.68 & 0.85 & 0.74 & 0.77 & 0.64 & 0.80 & 0.78 & 0.78 \\
\hline 9 Poland & 0.34 & 0.12 & 0.69 & 0.71 & 0.34 & 0.12 & 0.69 & 0.71 & 0.64 & 0.84 & 0.38 & 0.36 \\
\hline 10 Russia & 0.92 & 0.30 & 0.26 & 0.87 & 0.94 & 0.31 & 0.24 & 0.88 & 0.35 & 0.92 & 0.88 & 0.26 \\
\hline 11 SouthAfrica & 0.70 & 0.40 & 0.65 & 0.32 & 0.82 & 0.39 & 0.72 & 0.31 & 0.69 & 0.48 & 0.50 & 0.46 \\
\hline 12 Thailand & 0.74 & 0.74 & 0.83 & 0.83 & 0.78 & 0.76 & 0.82 & 0.86 & 0.78 & 0.78 & 0.86 & 0.81 \\
\hline 13 Turkey & 0.78 & 0.24 & 0.37 & 0.35 & 0.66 & 0.12 & 0.35 & 0.19 & 0.44 & 0.80 & 0.73 & 0.86 \\
\hline mean & 0.64 & 0.31 & 0.57 & 0.61 & 0.65 & 0.40 & 0.58 & 0.60 & 0.53 & 0.56 & 0.64 & 0.60 \\
\hline median & 0.70 & 0.26 & 0.65 & 0.71 & 0.68 & 0.31 & 0.69 & 0.71 & 0.50 & 0.68 & 0.73 & 0.52 \\
\hline
\end{tabular}




\section{Appendix 5. Comparison of Cycle Length to Claessens et al. (2011a and 2011b)}

Many of our findings on the length of financial cycles are similar to those found in Claessens et al. (2011a and 2011b). Like those papers, we find the median length for the equity price cycle in the range of 3 years and of property price cycle in the range of 4 years (Figure 1). To make the results easier to compare, in Figure 1, we: (i) estimate the median length across all turning points, rather than within each country first and then across countries; (ii) allow incomplete cycles in the turning point procedure; (iii) stop sample estimation in 2007Q4 as in Claessens; (iv) match Claessens' country sample, with exact match for AM; for EM, Claessens' has more data on Latin America, ours has more on Eastern Europe.

In two important aspects our findings are very different from the Claessens papers. First, Claessens papers find that the median length of the business cycle is under two years, while we find it is closer to six years, none of the countries have average length of the GDP cycle below three years (Appendix 3, Figure 1) and only twenty percent of the entire sample of turning points has upswing length of 1 year (Appendix 3, Figure 2). The Claessens result is at odds with the NBER dating of business cycles in the US, which finds an average cycle lasting an average of five years. It is also at odds with the results for the European business cycle by CEPR, which find that the timing of Euro Area recessions is similar to that of US recessions. Second, and as a result, the Claessens papers find that the financial cycle is longer than the business cycle, while we find that cycles in credit and real activity are of similar length, while cycles in asset prices are shorter. It is highly likely that the Claessens papers find a longer financial cycle because they are underestimating the length of the business cycle.

Drilling into the source of these differences, we find that the manner of averaging leads to an upward shift in the cycle length in our findings, but does not affect our results qualitatively. Specifically, for AMs, credit remains the longest cycle, followed by GDP, property, and lastly, equity; for EMs, the average credit cycle is roughly as long as GDP, followed by property and equity. Our preferred approach is to find the typical length of the cycle in a country and then average across countries to find the representative length for the AM and EM samples. The alternative is to average all results from turning point analysis in one AM or EM pool. This, however, leads to a downward bias in estimated length as the country with more frequent cycles will dominate the average with its larger number of shorter cycles, compared to a country with a small number of long cycles. This can be seen in the green line shifting below the red line in Figure 1, as we change the method of averaging. In our preferred averaging approach, each country's results get an equal weight and as a result the sample average is more representative of the underlying properties of the country group. 


\section{Figure 1. Cycle Length across Different Approaches}
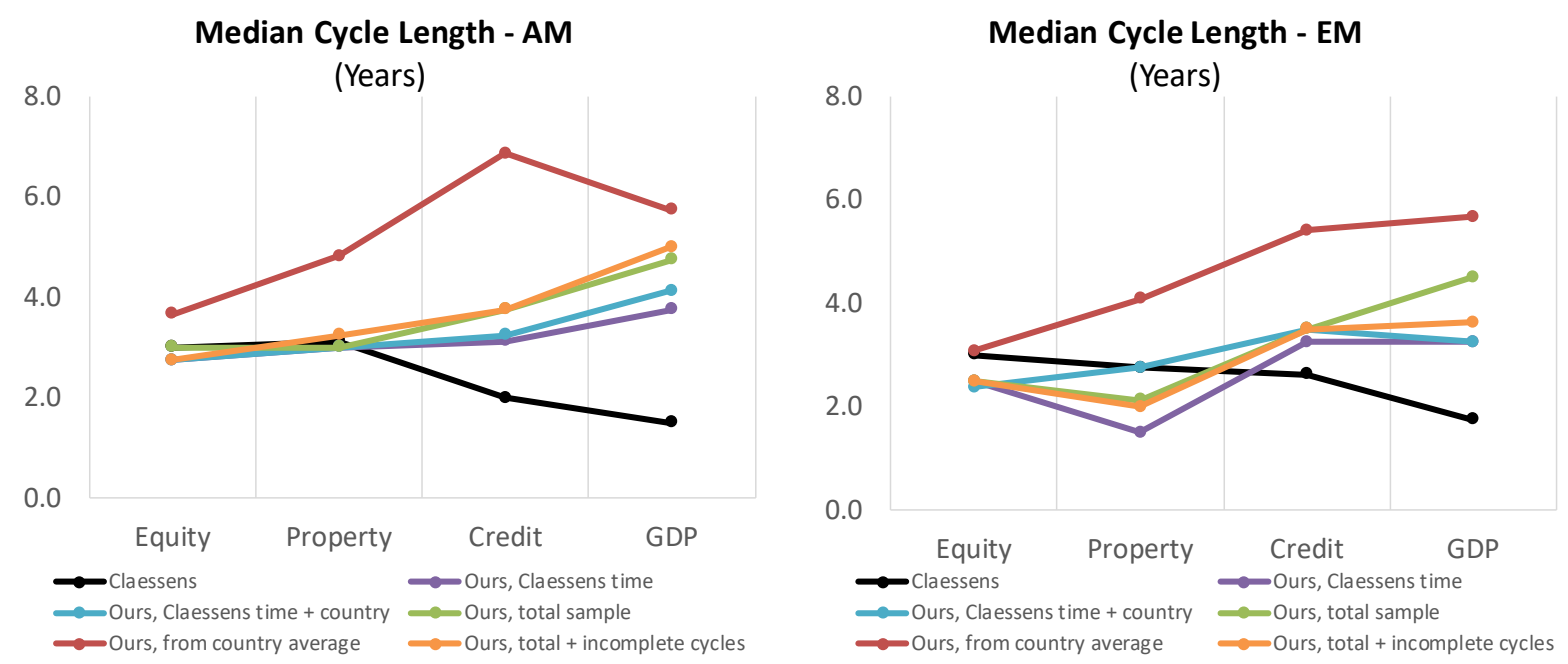

Notes: Red line is our results. Black line is the result from Claessens et al. (2011a and 2011b). Green line is average across turning points, without doing country averages first. Orange line is the same but allowing also incomplete cycles. Purple line is as before and stopping sample in 2007Q4 like in Claessens. Blue line is as before but try to match Claessens country sample: exact match for AM, for EM, Claessens has more data on Latin America, ours has more on Eastern Europe. 


\section{Appendix 6. Robustness Checks for EWS: AUROC Estimations}

The way to read these charts is as follows. First, an AUROC less than 0.7 indicates suboptimal performance, between 0.7 and 0.8 is good performance, and above 0.8 is excellent performance (Figures 1 and 2). Second, AUROC, just like STN, is used to assess the extent to which an indicator's value could signal financial overheating and the likelihood of a banking crisis down the road. When an AUROC is less than 0.5 - with the 0.5 score being the worst possible model performance, where the model cannot distinguish between crisis and non-crisis samples - it is a sign that that the opposite direction of the values may be predicting a crisis (Figure 4 and 5). In other words, these are the cases where a more negative value on the financial cycle gap indicates a higher probability of the crisis. In other words, both very large positive and very large negative financial cycle gaps are signs of financial system being out of balance and closer to a crisis.

\section{Figure 1. Two-Sided Filters (Overheating)}

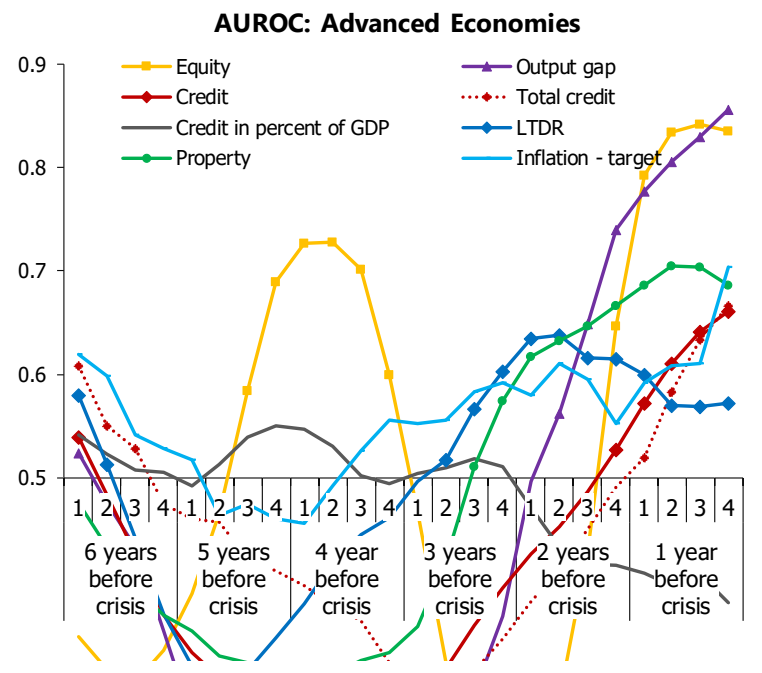

AUROC: Advanced Economies

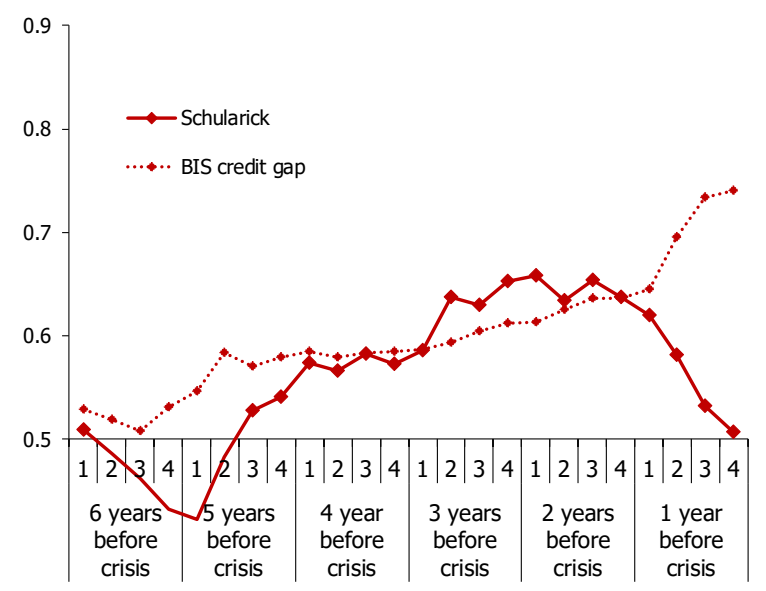

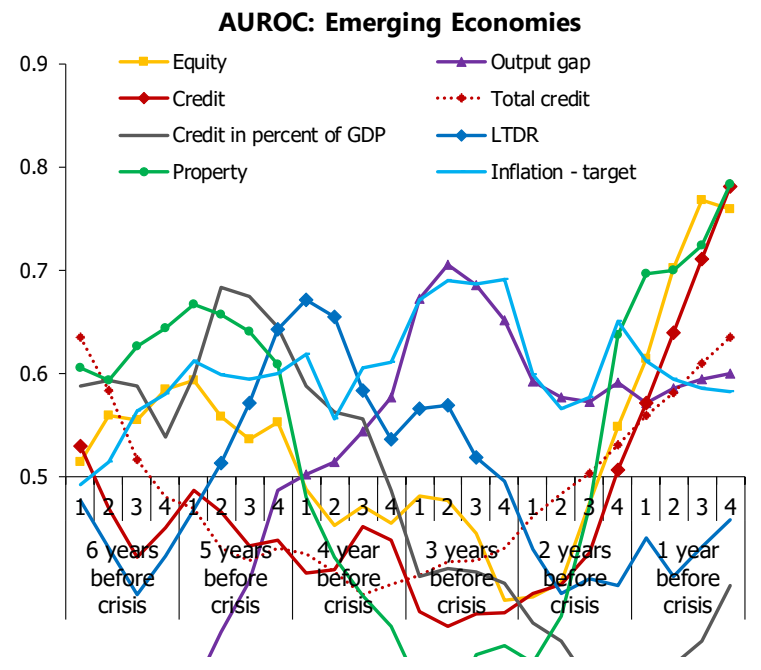

AUROC: Emerging Economies

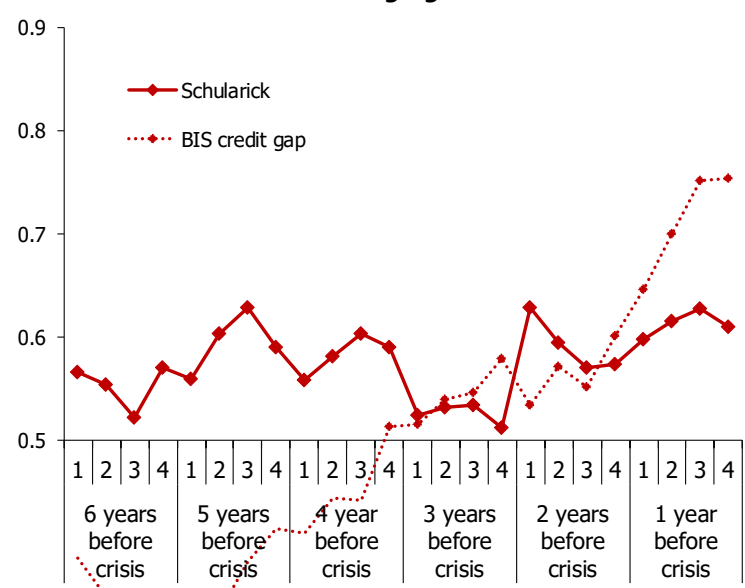




\section{Figure 2. One- Sided Filters (Overheating)}
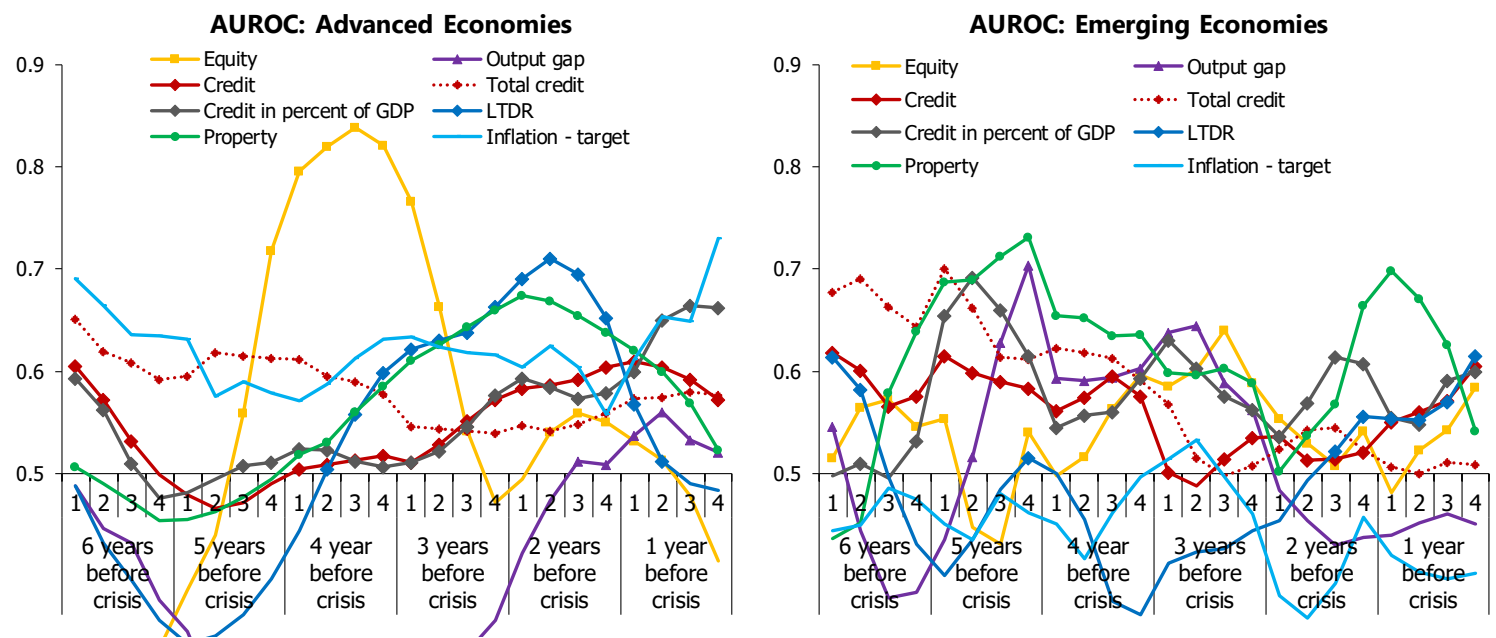

AUROC: Advanced Economies
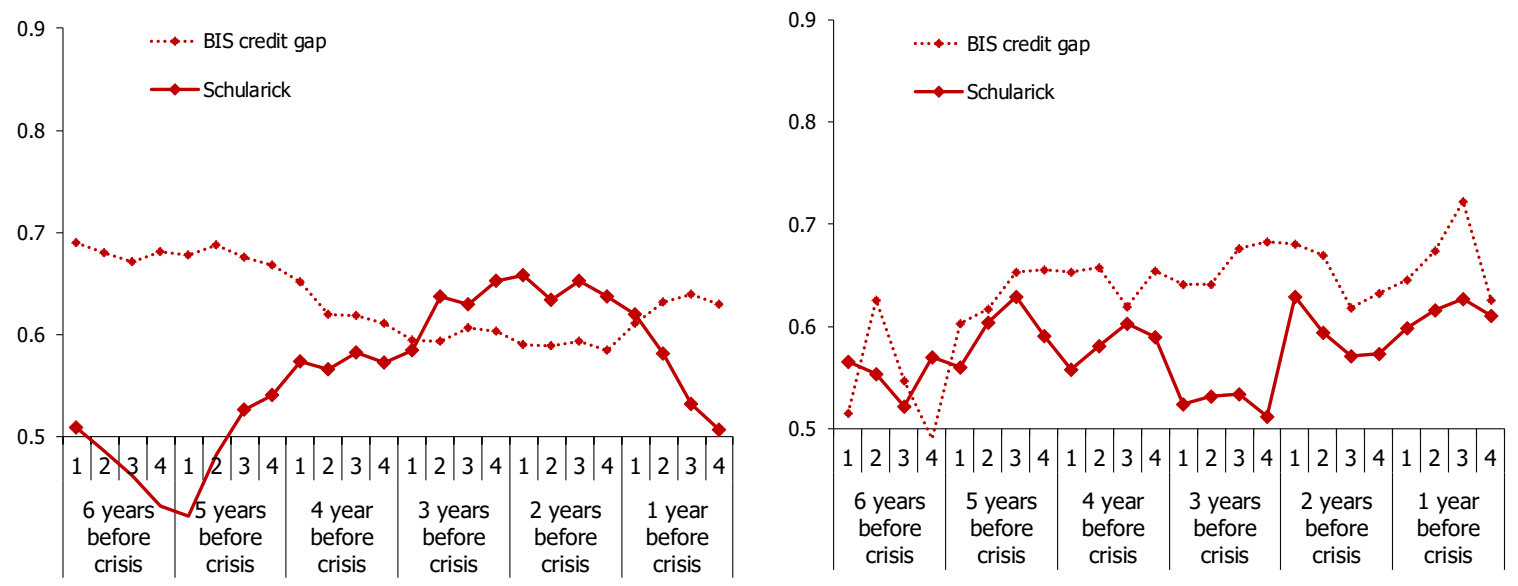


\section{Figure 3. Two-Sided Filters (Full Sample)}

AUROC: Advanced Economies

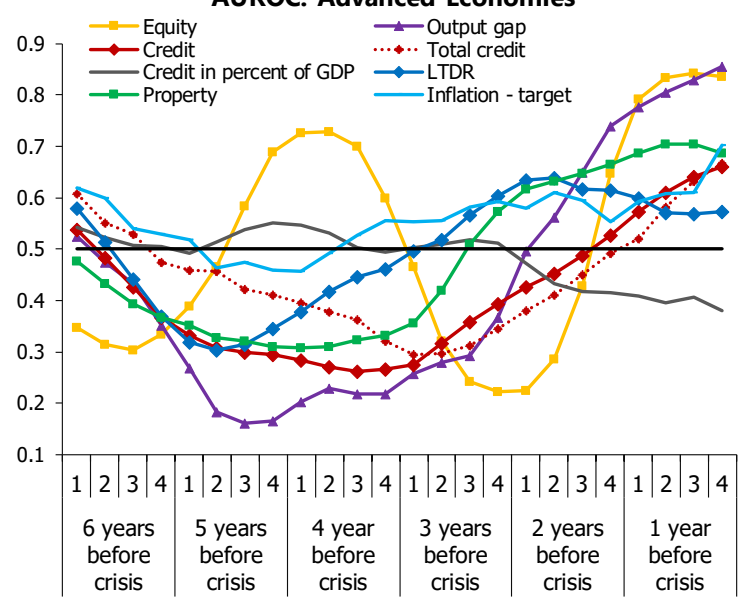

Signal to Noise Ratio: Advanced Economies

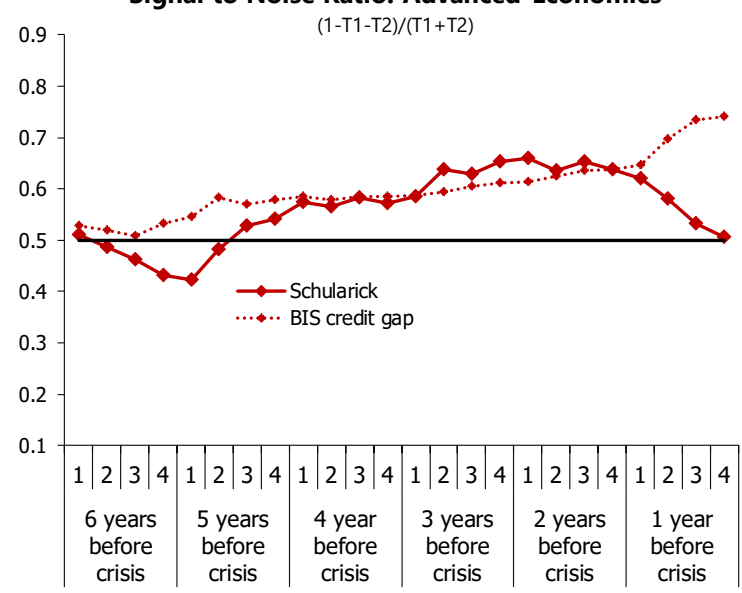

AUROC: Emerging Economies

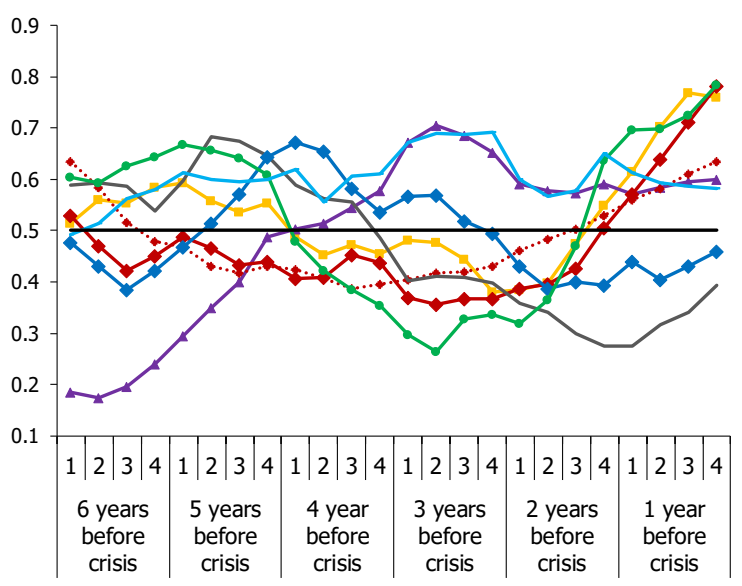

Signal to Noise Ratio: Emerging Economies $(1-\mathrm{T} 1-\mathrm{T} 2) /(\mathrm{T} 1+\mathrm{T} 2)$

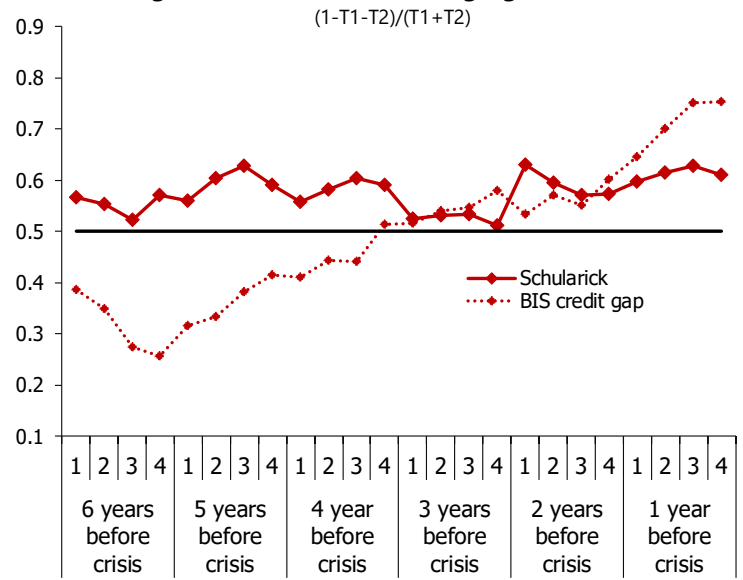




\section{Figure 4. One-Sided Filters (Full Sample)}

AUROC: Advanced Economies

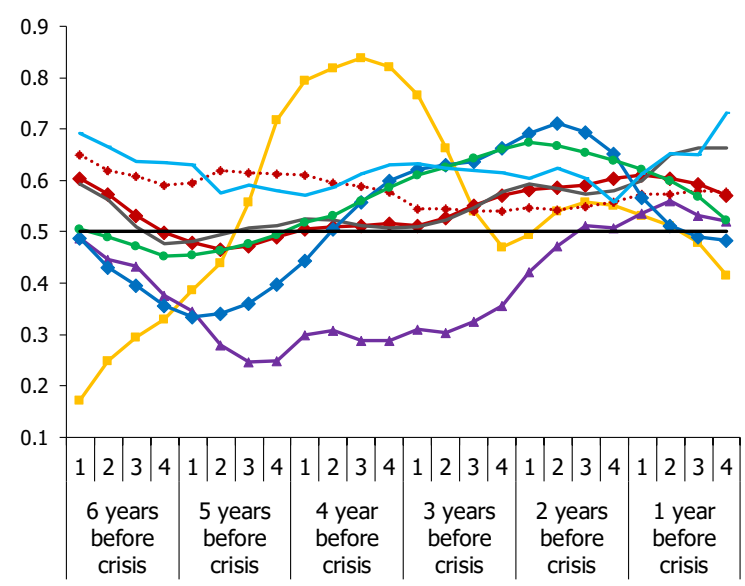

Signal to Noise Ratio: Advanced Economies

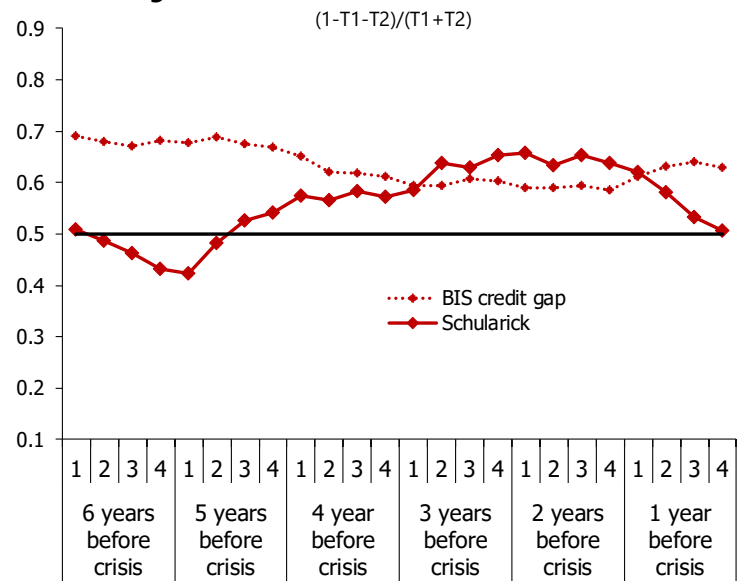

AUROC: Emerging Economies

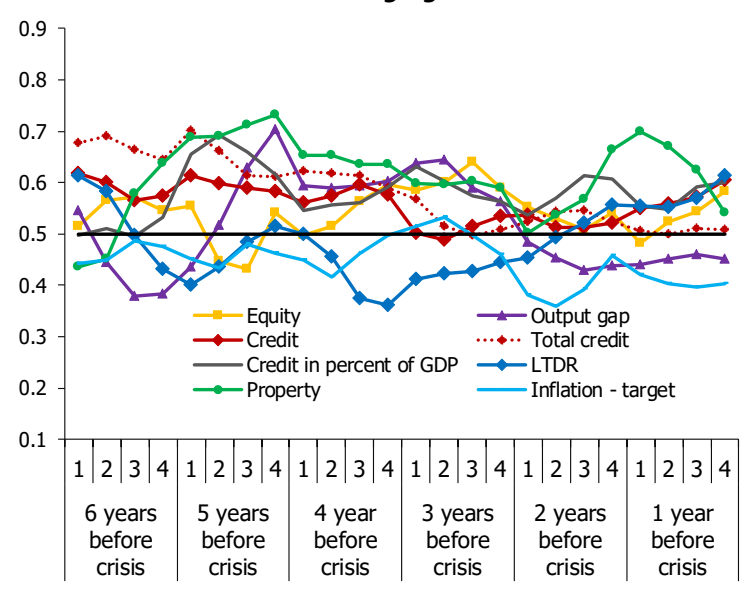

Signal to Noise Ratio: Emerging Economies

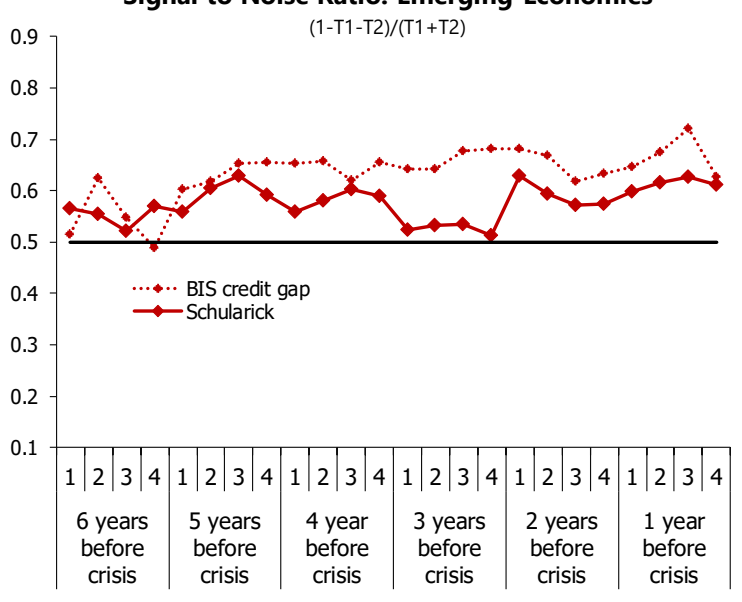

